\title{
The origins of the western Uralic s-cases revisited: historiographical, functional- typological and Samoyedic perspectives
}

\author{
To kill an error is as good a service as, \\ and sometimes even better than, \\ the establishing [of] a new truth or fact. \\ Charles Darwin
}

The paper presents a comprehensive reappraisal of the origins of the so-called $s$-cases in Saami, Finnic, Mordvin and Mari. According to the received view, the element ${ }^{*}-s$ - that is present in most of the basic local case markers in these languages originates in the so-called ${ }^{*} s$-lative whose origin has remained unknown. As the dominant theory suffers from various methodological shortcomings, alternative proposals have also been presented yet largely ignored. As the first functionally and typologically substantiated hypothesis on the issue, the paper proposes that the $s$-cases originate in Proto-Uralic postpositional phrases. Confronting the daunting task of identifying cognates of the $s$-cases elsewhere, it is proposed that they can be related to at least the Samoyed local cases with the element ${ }^{*}$-ntz-.

1. Introduction

2. Preliminaries: the position of the $s$-cases in the Uralic language family

2.1. On the genetic classification of the Uralic languages
2.2. The $s$-cases
2.3. On the so-called internal and external local cases
2.4. Summary

3. History of research

3.1. Prehistory (before 189o)

3.2. The origins of the ${ }^{*} s$-lative (1890)

3.3. The canonization of

the ${ }^{\star}$ s-lative (after 1890)

3.4. Alternative hypotheses

and their reception
4. Critical evaluation of the received view 4.1. Lative cases as deus ex machina 4.2. When case markers are combined 4.3. Additional remarks

5. Discussion and further remarks:

What can be said about the origins of the $s$-cases?

5.1. A Samoyed perspective on the $s$-cases

5.2. Old problems and new horizons

6. Conclusion 


\section{Introduction}

Uralic languages are well-known for their rich inflectional and derivational morphology manifested in, for example, more than dozen or even two dozen morphological cases in some languages. By far the best known languages both within and outside traditional Uralistics are Hungarian as well as Finnish and Estonian of the Finnic branch of the family. For example, Hungarian noun morphology is famous for as many as three or dialectally even four - tripartite series of local cases that can roughly be described as combinations of the semantic features 'from' (source), 'at' (location) and 'to' (direction) on one dimension, and 'on' (surface), 'in' (inside) and 'near' (vicinity) on the other. Within the Finnic branch, Veps has a quite similar local case system (Table 1). As for Finnish and Estonian, there are only two such series: the so-called internal and external cases, often known as $s$-cases and $l$-cases, respectively. Both sets have been traditionally considered defining features of the Finnic branch in general. On the other hand, $s$-cases and $l$-cases have long been central in various attempts to understand the prehistory of the Finnic languages in relation to that of other branches in the Uralic language family.

\begin{tabular}{|c|c|c|c|}
\hline & Source ('from') & Location ('at') & Direction ('to') \\
\hline $\begin{array}{l}s \text {-cases or } \\
\text { internal cases } \\
(\text { südäisijakändod) }\end{array}$ & $\begin{array}{l}\text { elative } \\
\text { käde-späi } \\
\text { 'from the hand' }\end{array}$ & $\begin{array}{l}\text { inessive } \\
\text { käde-s } \\
\text { 'in the hand' }\end{array}$ & $\begin{array}{l}\text { illative } \\
\text { käd-he } \\
\text { '(in)to the hand' }\end{array}$ \\
\hline $\begin{array}{l}\text { l-cases or } \\
\text { external cases } \\
(\text { irdsijakändod) }\end{array}$ & $\begin{array}{l}\text { ablative } \\
k \ddot{d d e} \text {-lpäi } \\
\text { 'off the hand' }\end{array}$ & $\begin{array}{l}\text { adessive } \\
k \text { äde-l } \\
\text { 'on the hand' }\end{array}$ & $\begin{array}{l}\text { allative } \\
\text { käde-le } \\
\text { 'onto the hand' }\end{array}$ \\
\hline $\begin{array}{l}\text { vicinal cases } \\
\text { (lähesijakändod) }\end{array}$ & $\begin{array}{l}\text { egressive } \\
\text { käde-nnopäi } \\
\text { 'from the vicinity } \\
\text { of the hand' }\end{array}$ & $\begin{array}{l}\text { approximative I } \\
\text { käde-nno } \\
\text { 'in the vicinity } \\
\text { of the hand' }\end{array}$ & $\begin{array}{l}\text { approximative II } \\
\text { käde-nnoks } \\
\text { 'to the vicinity } \\
\text { of the hand' }\end{array}$ \\
\hline
\end{tabular}

Table 1: The so-called $s$-cases (internal cases), $l$-cases (external cases) and vicinal cases in Veps exemplified by the noun käzi 'hand; arm' (cf. Kittilä \& Ylikoski 2011: 41-43; Ylikoski 2011: 251-252; Tables 4 and 9 below) 
Most of the Hungarian local case series are unanimously regarded as a result of morphological and semantic bleaching of postpositions during the Common Era and even the documented history of Hungarian; in a word, Hungarian local cases are literally textbook examples of grammaticalization (e.g., Erkki Itkonen 1966b: 294; Anttila 1989: 149, 258; Blake 2001: 165; Hopper \& Traugott 2003: 111), with only partial cognates in Mansi and Khanty (Honti 2006). However, the origins of the Finnic local cases are considerably less transparent. Although the origins of the Finnic local cases have often been pursued as the origins of the Finnic (or only Finnish) cases per se, both the $s$-cases and $l$-cases are usually regarded as having cognates in other branches of the family. Moreover, the quest for their origins has been intertwined with the pursuit of the genetic classification and internal makeup of the language family.

In a nutshell, the existence of the so-called s-cases in Saami, Finnic, Mordvin and Mari has been considered a central morphological argument in favor of the so-called Finno-Volgaic affinity, Proto-Finno-Volgaic being an intermediate proto-language of these four branches. On the other hand, the proposed cognates of the Finnic $l$-cases in Permic and partly in Mari have been interpreted as convergent developments in the individual branches, as such cognates are absent in Saami and Mordvin that ought to share at least remains of such innovations if they went beyond ProtoFinno-Volgaic and back up to Proto-Finno-Permic, as suggested by the traditional, binary branching classification of the Uralic languages. To explicate the subject matter of the present study, Table 2 gives a general overview of the $s$-cases in the most conservative variants of each of the four branches.

Even though nearly all modern general descriptions of the historical development of Finnic languages present the received views about the origins of the local cases as quite unproblematic, a deeper exploration into the history of their research reveals serious shortcomings and unanswered questions with respect to both the formal and functional requirements of plausible historical explanations. According to the received view (for quick reference, see Figure 4 in Section 4.1), the element ${ }^{*} s$ of the so-called $s$ cases in the so-called Finno-Volgaic languages goes back to the so-called ${ }^{*}$ s-lative case in Proto-Finno-Volgaic, but various alternative suggestions have been presented ever since the advent of historical Uralistics in the mid-19th century. Although none of these neglected hypotheses are more satisfactory than the received view, it appears that the prevailing view is 
The origins of the western Uralic s-cases revisited

\begin{tabular}{|c|c|c|c|}
\hline & $\begin{array}{l}\text { Source } \\
\text { (elatives; 'from') }\end{array}$ & $\begin{array}{l}\text { Location } \\
\text { (inessives; 'at') }\end{array}$ & $\begin{array}{l}\text { Direction } \\
\text { (illatives; 'to') }\end{array}$ \\
\hline $\begin{array}{l}\text { South Saami } \\
\text { (Saami) }\end{array}$ & $\begin{array}{l}\text {-ste, -stie } \\
\text { dålle-ste } \\
\text { gïete-ste }\end{array}$ & $\begin{array}{l}\text {-sne, -snie } \\
\text { dålle-sne } \\
\text { gïete-sne }\end{array}$ & $\begin{array}{l}\text {-se, -sse, -n } \\
\text { dålle-se } \\
\text { gïete-se }\end{array}$ \\
\hline Finnish (Finnic) & $\begin{array}{l}\text {-sta, -stä } \\
\text { tule-sta } \\
\text { käde-stä }\end{array}$ & $\begin{array}{l}\text {-ssa, -ssä } \\
\text { tule-ssa } \\
k \ddot{d} d e-s s a ̈\end{array}$ & $\begin{array}{l}-(h) V n,-s e e n \\
\text { tule-(h)en } \\
\text { käte-(h)en }\end{array}$ \\
\hline Erzya (Mordvin) & $\begin{array}{l}\text {-sto, -ste } \\
\text { tol-sto } \\
\text { ked'-ste }\end{array}$ & $\begin{array}{l}-s o,-s e \\
\text { tol-so } \\
\text { ked'-se }\end{array}$ & $\begin{array}{l}-s \\
\text { tol-s } \\
\text { ked'-s }\end{array}$ \\
\hline East Mari (Mari) ${ }^{1}$ & - & $\begin{array}{l}\text {-šte, -što, -štö } \\
\text { tulà-što } \\
\text { kidâ-šte }\end{array}$ & $\begin{array}{l}-\check{s}(k e),-\check{s}(k o), \\
-\check{s}(k \ddot{o}) \\
\text { tulâ-̌s }(k o) \\
k i d \hat{\partial}-\check{s}(k e)\end{array}$ \\
\hline
\end{tabular}

Table 2: The so-called $s$-cases in Saami, Finnic, Mordvin and Mari exemplified with the words for 'fire' and 'hand; arm'

not significantly better founded either. The present paper is a considerably extended and improved follow-up of a previous discussion on this issue in a survey of the origins of directional case suffixes in the Uralic languages of Europe (Ylikoski 2011).

The Hungarian local case series mentioned above fall largely outside the scope of the present paper, but the recent research on the so-called $l$-cases in Finnic as well as in Permic will be commented upon in more detail. As a matter of fact, the present reappraisal of the origins of the $s$-cases is largely analogous to Aikio and Ylikoski's (2007; forthcoming) recent reassessment of the received view on the emergence of the Finnic $l$-cases: in these studies it is claimed that the earlier theory, which was loosely based on the Finnic oikonym suffix -la, ought to be rejected in favor of the functionally and typologically more tenable theory about the postpositional origins of the $l$-cases that go back to the Uralic spatial stem * $\ddot{u} l(i)$ - 'location on/above' (e.g., Proto-Uralic ${ }^{\star} k a ̈ t i-n$ ül-nä > Finnish kädellä 'on the hand', ${ }^{\star} t u l i-n$ $\ddot{u} l$-tä $>$ tulelta 'off the fire'), fully in line with the more recent development of the so-called $v$-cases in Southern Permyak. Furthermore, the research history of the $s$-cases is also related to questions of the origin of cases such as the Finnic and Mordvin translative and, as it turns out, to even more distant case markers in Samoyed. 
The structure of the paper is as follows: After a brief introduction to the taxonomy of the Uralic languages (Section 2.1) as well as the inventory (Section 2.2) and semantics (Section 2.3) of s-cases in the westernmost Uralic languages, Section 3 provides a detailed overview of the research on the origins of the cases in question. The history of research is divided into the earliest 19th-century speculations on the origins of the $s$-cases (Section 3.1), followed by the reconstruction (Section 3.2) and subsequent canonization (Section 3.3) of the ${ }^{*}$-lative as the core element of the $s$-cases. Alternative hypotheses and their reception are described in Section 3.4. In Section 4 , the received view is evaluated critically by paying specific attention to the challenges of the labile Uralistic concept of lative as a synchronic-cumdiachronic device to explain the internal makeup of local case markers (Section 4.1). In Section 4.2, the so-called lative theory as an explanation of the $s$-cases is compared with reliably attested case stacking phenomena in Uralic languages, and certain less central arguments are commented on and called for - in Section 4.3.

In conclusion, Section 5 draws the threads together and provides a general discussion and further remarks on the topic, and attempts to provide a revised and realistic view of the ultimate possibilities of explaining the origins of the s-cases. As it turns out, it is possible to take further steps over the cautious attitude expressed in Ylikoski's (2011: 265) preliminary conclusion that the origin of the western Uralic s-cases must "be regarded unsolved or at best unclear": it appears that there is a possibility to relate the $s$-cases to two Samoyed local case markers that could go back to Pre-ProtoSamoyed postpositional phrases governed by postpositions beginning in Proto-Uralic ${ }^{*}$ s (Section 5.1). By no means does this alternative resolve all problems, but rather it opens up new horizons to the critical re-evaluation of Uralic historical morphology. ${ }^{2}$

As the scope of this paper comprises the origins and the long history of research of a number of case suffixes in a number of Uralic languages, some precautions and disclaimers are in order: The paper does in no way attempt to go into all relevant details of the use of $s$-cases in individual Uralic languages. For the purposes of the present study, most of the commonly accepted branch-internal reconstructions are assumed to be true without detailed discussion or references to all relevant sources, not to speak of the variation within individual languages. For example, the dialect map depicting the illative forms of the simple two-syllable words aitta 'storehouse, shed' and perä 'rear' in Finnish (Kettunen 1940, Map 182) - 
only one of about dozen languages of the Finnic branch - provides areal distribution of as many as eleven morphological realizations of the illative singular, and even these are partly indifferent to the existence of the final - $n$ that has been of utmost importance in pursuit of the ultimate origins of the case in question (e.g., aittaa(n), aitta(n), aittoa(n), aittua(n), aittoo, aittahan, aithan, aithaan, aittah, aittasse and aittassi for aitta 'storehouse, shed').

Furthermore, the study is almost entirely limited to singular case forms in absolute declensions - with no special attention to plural forms (commonly regarded as recent developments in individual branches of Uralic) or forms with possessive suffixes, despite their importance in many branch-internal reconstructions on which this study relies. By the same token, even the importance of some bigger topics of discussion is reduced to a minimum. Most importantly, the recent discussion about the origins of the Saami illative case suffixes by Larsson (2009, 2012: 131-133) and Sammallahti (2009) is treated by simply adopting Sammallahti's view about an originally uniform suffix ${ }^{*}$-sen $\left(<^{*}\right.$-sin) instead of the etymologically heterogeneous origins $\left({ }^{*}-\right.$ sen and ${ }^{*}$-jen $)$ advocated by Larsson, as the details of the competing explanations are not crucial for the main topic of this study. ${ }^{3}$

\section{Preliminaries: the position of the s-cases in the Uralic language family}

\section{I. On the genetic classification of the Uralic languages}

In order to define and delimit the scope of the present study, I wish to shortly refer to the various views concerning the genetic makeup of the whole Uralic language family. The most traditional, binary branching classification (Figure 1) going back to the end of the 19th century is still supported by some scholars. However, this view has also been re-evaluated with well-founded skepticism, and a number of competing views have been presented since K. Häkkinen $(1983,1984)$ (e.g. Figures 2 and 3; for more details, see, e.g., J. Häkkinen 2009, 2013: 194-203). This also affects the time-depth of various proto-languages, as the estimates for ProtoUralic vary as much as between 7,000 and 2,000 BC. ${ }^{4}$ 
Saami Finnic Mordvin Mari Permic Hungarian Mansi Khanty Samoyed

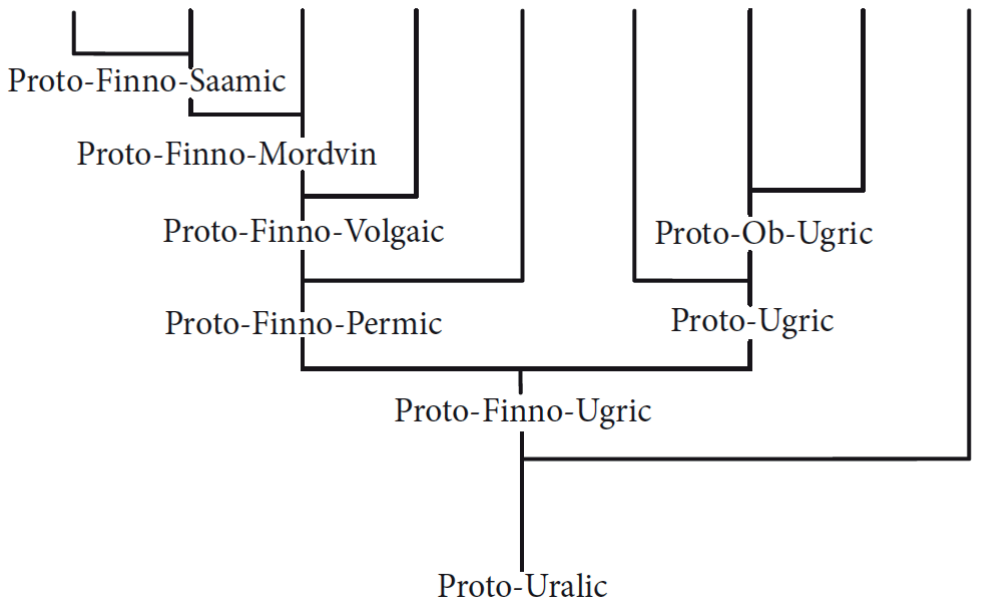

Figure 1: The most traditional taxonomy of the Uralic languages (cf. e.g. Donner 1879: 157; Janhunen 2001: 39)

Saami Finnic Mordvin Mari Permic Hungarian Mansi Khanty Samoyed

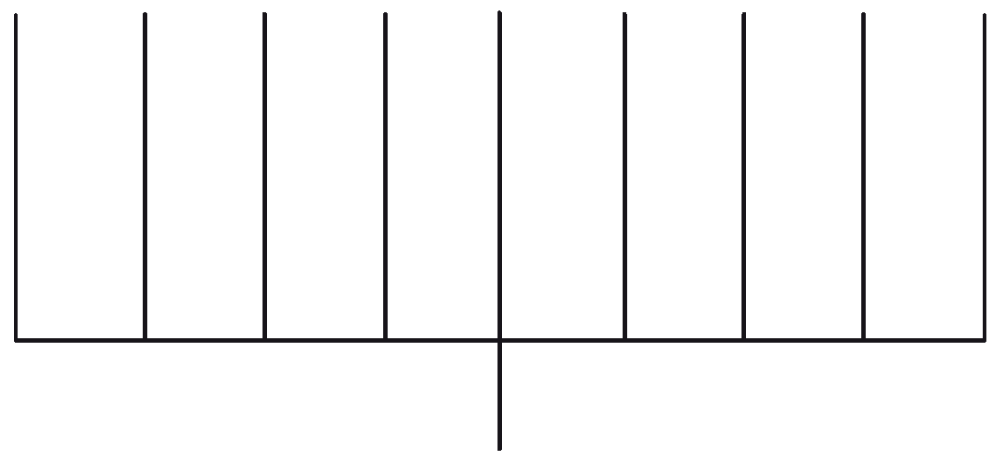

Proto-Uralic

Figure 2: The Uralic languages according to Salminen (1999: 20; cf. already K. Häkkinen 1983: 384) 
Saami Finnic Mordvin Mari Permic Hungarian Mansi Khanty Samoyed

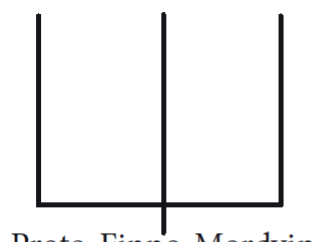

Proto-Finno-Mordvin

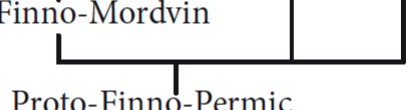

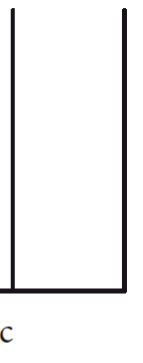

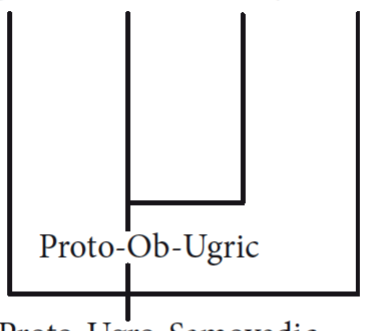

Proto-Ugro-Samoyedic
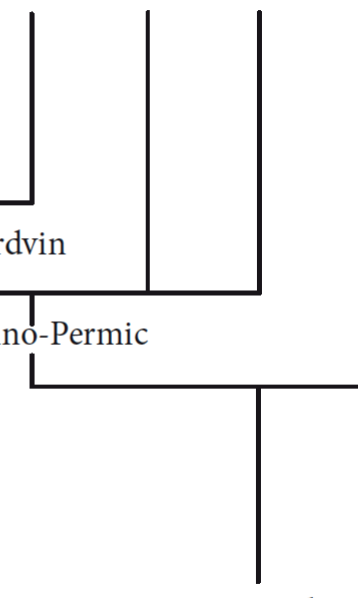

\section{Proto-Uralic}

Figure 3: The Uralic languages according to J. Häkkinen (2007: 63-81; 2013: 202)

Although there is a complete unanimity on the members of the Uralic family, the lack of consensus on the number and interrelations of the main branches of Uralic must have consequences for analyses and reconstructions of the historical morphology in the individual branches and the whole language family, although as we go deeper into the reconstructions of proto-languages, the role and possibilities of morphology tend to diminish at the expense of historical phonology and word etymology.

As mentioned above, the existence of the so-called s-cases in Saami, Finnic, Mordvin and Mari has been considered a central morphological argument in favor of Proto-Finno-Volgaic, an intermediate proto-language of these four branches (Figure 1). However, the other side of the coin is that as the recent past decades have witnessed a number of reassessments of the internal structure of the Uralic family, one of the most commonly debunked intermediate proto-languages has been Proto-FinnoVolgaic. Biased etymological statistics aside, there is little phonological or morphological evidence for truly Finno-Volgaic innovations. As seen in the so-called comb model presented by Salminen (1999; Figure 2), all of the four branches with $s$-cases may be seen on par with the five branches without such cases, and even more traditional proponents of branching family trees have often more or less explicitly abandoned the Finno-Volgaic affin- 
ity, while at the same time paying increasing attention to the multifaceted relations between Saami, Finnic and Mordvin that might be better analyzed as having a ternary rather than binary structure (e.g., J. Häkkinen 2009, 2013: 194-203; Saarikivi 2011: 106-110). The remaining proponents of binary branching classifications have also considered the possibility that the Saami languages may have branched out before the separation of Finnic and Mordvin (Janhunen 2009). On the other hand, as pointed out by J. Häkkinen (2012: 21) and Zhivlov (2014: 115-117), it is also possible to observe remarkable phonological innovations shared by Saami and Mordvin, thus setting the descendants of a hypothetical Saami-Mordvin protodialect of West Uralic apart from Finnic.

In the wake of new and more variegated views on the internal structure of Uralic, new labels have been needed for new language groupings. For the purposes of the present study, the most important label is "West(ern) Uralic", which is most often used as a joint label for Saami, Finnic and Mordvin or their common ancestor, the West Uralic proto-language or the westernmost dialect of Proto-Uralic (e.g., J. Häkkinen 2009, 2013: 198-199; Aikio 2012: 70; Kallio 2012: 169). As far as the historical Chude, Merya, Muroma and Meshchera tribes are concerned, it is understandable that their idioms, too, have been characterized as West Uralic languages (Rahkonen 2013: 242243). However, especially as long as the renewed positions of the less western Mari and Permic remain unclear (J. Häkkinen 2009, 2013: 202), it ought to be possible to extend the concept of western Uralic languages to comprise Mari, at least in an areal, albeit not necessarily genetic, sense of the word. Referring to the emergence of $s$-cases, J. Häkkinen (2012: 21-22) states that Mari is similar to, but "not a core member" of West Uralic.

In the current absence of a consensus regarding the issue, this is precisely the reason for titling the present study as "The origins of the western Uralic $s$-cases revisited" without writing the subject matter in capitals and thus assigning a definite status to any group of western Uralic languages. However, it goes without saying that despite its western location on the map, Hungarian is not considered a western Uralic language in the present diachronic study. Instead, it seems possible to use the words western Uralic in a continuum-like manner to refer to the branches on the left-hand side of Figures 1-3, in the sense that the Saami and Finnic languages are more western than Mordvin, not to speak of Mari or even Permic, although the latter certainly belong to the western sphere better than those on the righthand or eastern side of the language family. It must be emphasized that 
for the purposes of the present study, the four westernmost branches that seem to share at least part of their $s$-cases can be considered a valid areal unit regardless of their genetic relationships, which will always remain without a definite answer, not least due to the unknown number and nature of unknown lost languages in the vicinity of today's western Uralic languages.

\subsection{The $s$-cases}

The subject matter of this study was briefly presented already in Table 2 above. To provide a slightly more abstract picture of the present-day languages as successors of Saami, Finnic, Mordvin and Mari proto-languages, the aforementioned cases are repeated in Table 3 in a simplified format that includes only the most common or apparently most original allomorphs of the present-day case markers as well as the least suspicious, relatively shallow reconstructions of each case for the respective proto-languages.

Although Tables 2 and 3 continue the Uralistic tradition of viewing local cases as predominantly tripartite local case systems consisting of separate cases for source ('from'), location ('at') and direction ('to'), many objections and amendments ought to be made. It goes without saying that comprehensive synchronic descriptions of local case systems in more

\begin{tabular}{|c|c|c|c|}
\hline & $\begin{array}{l}\text { Source } \\
\text { (elatives; 'from') }\end{array}$ & $\begin{array}{l}\text { Location } \\
\text { (inessives; 'at') }\end{array}$ & $\begin{array}{l}\text { Direction } \\
\text { (illatives; 'to') }\end{array}$ \\
\hline $\begin{array}{l}\text { South Saami } \\
(<\text { Proto-Saami) }\end{array}$ & -ste $\left(<^{*}-s t a\right)$ & - sne $\left(<^{*}\right.$-sna $)$ & $\begin{array}{l}-s e \\
\left(<^{*}-\operatorname{sen}<^{*}-\sin \right. \\
\left.<^{*}-\operatorname{si\eta }\right)\end{array}$ \\
\hline $\begin{array}{l}\text { Finnish } \\
\text { (< Proto-Finnic) }\end{array}$ & $-s t a\left(<^{*}-s t a\right)$ & $-s s a\left(<^{*}-s n a\right)$ & $\begin{array}{l}-(h) V n \\
\left(<{ }^{*}-h e n<\right. \\
\left.{ }^{*}-\sin <{ }^{*}-\sin \right)\end{array}$ \\
\hline $\begin{array}{l}\text { Erzya } \\
\text { (< Proto- } \\
\text { Mordvin) }\end{array}$ & -sto $\left(<^{*}-\right.$ sta $)$ & -so $\left(<<^{*}-\right.$ sna? $)$ & $-s\left(<<^{*}-\operatorname{si\eta } ?\right)$ \\
\hline $\begin{array}{l}\text { East Mari } \\
(<<\text { Pre- } \\
\text { Proto-Mari) }\end{array}$ & - & -šte $\left(<<^{*}\right.$-sna? $)$ & $-\check{s}(k e)(<?)$ \\
\hline
\end{tabular}

Table 3: The so-called s-cases in Saami, Finnic, Mordvin and Mari (with most obvious proto-forms in parentheses) 
than twenty individual languages of the Saami, Finnic, Mordvin and Mari branches fall outside the scope of the present study, but some general comments are in order. To begin with, many western Uralic languages have more local cases than those depicted above. Although the South Saami and Finnish $s$-cases fit the tripartite division in that the three $s$-cases of South Saami constitute the entire set of undisputed local cases in the language and their Finnish counterparts constitute exactly half of the total of six undisputed local cases - the $s$-cases on a par with the $l$-cases -, other Finnic languages such as Veps have also terminatives ('up to; until') and prolative ('along') local cases, and other Saami languages such as North Saami have only two local cases, as the Proto-Saami inessive and elative have merged into a single case known as locative. A similar development is attested in certain varieties of Karelian, and in other varieties the loss of the source vs. location distinction has been compensated with new morphological differences (cf. Section 5.2 below). On the other hand, the Mordvin languages possess not only one directional local case (illative in $-s$ ) but also another one called lative (e.g. Erzya $-v /-j$ ), and the local case system also includes the prolative. Case-like prolative morphemes are not entirely absent in Saami either (Ylikoski 2015). (For a general description of European Uralic local cases, see, e.g., Kittilä \& Ylikoski 2011, Ylikoski 2011 and references therein.)

As for Mari, both literary standards and most of the spoken varieties lack separative cases as morphological markers of source altogether. The dialectal ablative marker (-leć) has not been considered historically an $s$ case in any case. On the other hand, the Mari languages do have cases called "latives" in addition to the illative in $-\check{s}(k e)$. I repeat my earlier position on the nature of such cases with respect to other, ordinary local $s$ cases:

The picture of $s$-cases is further complicated by another case suffix, as the presentday Mari also possesses a case labeled as "lative". Despite its name, the Mari lative suffix -(e)š hardly deserves to be characterized as a directional case marker, as none of its multifaceted functions includes concrete movement or transfer in place (or even in the sphere of possession). Rather, the idea of its "directionality" seems to be based on the use of the lative in a variety of syntactic contexts that belong to the secondary grammatical functions of some of the directional cases in other Uralic languages. Such functions include expressions such as pel ak-eš užal-aš [half priceLAT sell-INF] 'to sell at ("to") half price' and sar-eš kol-aš [war-LAT die-INF] 'to die in ("to") a war' (for more examples, see e.g. Alhoniemi 1993: 55-56). Even though 
many of these functions may be related to those typical of the primary functions of directional cases (as also suggested by the cross-linguistic data discussed by Rice \& Kabata 2007), there are no tenable reasons for regarding the Mari lative as a directional case on this basis only. (Ylikoski 2011: 262, Note 23.)

In spite of the above simplification, it must be admitted that the many functions of the Mari lative and more ordinary local cases form an extraordinarily complex system that has been discussed comprehensively by Alhoniemi (1967); see also Bereczki (2002: 34ff.) and Alhoniemi (2004: 326-327) for diachronic discussion. For the present purposes, however, two pairs of sentences suffice to illustrate the main difference between the two cases. Examples (1-2) and (3-4) contain the nouns tul 'fire' and kid 'hand; arm', respectively:

\section{East Mari}

(1) Куржын пура да, тошто рывыж малакайжым тульиш шуэн колта.

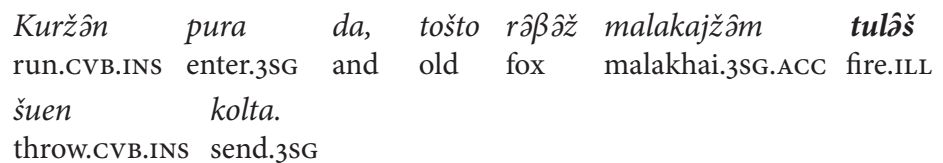

'She rushed into the house and thrust the old fox malakhai (fur hat) into the fire.'

(2) Куван у малака[я]т уке, тоштыжат уке, тулэш йӥлалтэн.

Kußan u malakaj=at uke, tošt $\hat{z} \check{z}=a t$

old.woman.GEN new malakhai=and NEG.EX old.3SG=and

uke, tuleš jülalten.

NEG.EX fire.LAT burn.PST2.3SG

'The old woman does not have a new malakhai nor the old one, having burned it in the fire.' (Sokolov 2013)

(3) Иисус вич кинде ден кок колым кидыш нальн, пылпомышко ончалын да благословитлен.

Iisus Bić kinde den kok kolâm kidâš nalân, Jesus five bread and two fish.ACC hand.ILL take.cvB.Ins pâlpomâško onćalân da blagosloßitlen. heaven.ILL look.PST2.3SG and give.thanks.PST2.3SG 'Taking the five loaves and the two fish in(to) his hand, Jesus looked up to heaven and gave thanks.' (USu: Mark 6:41) 
(4) Тунемшыж-влак шурно парчам кёрыныт да, кидеш туржын, кочкыныт.

$\begin{array}{lllll}\text { Tunemšâž-ßlak } & \text { šurno parćam kürânât } & \text { da, } & \text { kideš } \\ \text { disciple.3SG-PL } & \begin{array}{l}\text { crop twig.ACC } \\ \text { pick.PST2.3PL }\end{array} & \text { and } & \text { hand.LAT } \\ \text { turžân, } & \text { koćkânât. } & & & \\ \text { crumple.CVB.INS } & \text { eat.PST2.3PL } & & & \end{array}$

'His disciples were picking heads of grain, crumpling them in their hands, and eating them.' (USu: Luke 6:1)

As already mentioned, the lative case as seen in (2) and (4) cannot really be regarded as a directional case in the sense of expressing concrete movement or transfer in space, as is present in (1) and (3). On the other hand, it is possible to analyze the lative as referring to static location, but it would be equally difficult to analyze the lative in terms comparable to the straightforwardly locative nature of the inessive case. As the lative forms in sentences like (2) and (4) or the above-mentioned examples 'sell at half price' and 'die in a war' seem to be governed by non-motion verbs denoting change of state, they could possibly be best described as some kind of locative depictive secondary predicates (cf. Schultze-Berndt \& Himmelmann 2004: 115-117), but for the time being, such an enterprise must be left to more detailed synchronic studies of Mari grammar. However, there are many contexts such as complements of the verb šinćaš 'sit down' in which both the lative and illative are allowed: divaneš šinčaš 'sit down on the couch' and divanâš šinčaš id. apparently do not differ in meaning (Riese et al. 2012: 102).

In any case, regardless of the extensive description of the functions of the Mari illative and lative (Alhoniemi 1967), it still cannot be taken as self-evident that the Mari lative originates from the same source as the rest of the directional $s$-cases in western Uralic. Many semantic features of the Mari lative and the illatives in Saami, Finnic and Mordvin certainly support this assumption, though. From a morphological and phonological point of view, the rather unrevealing internal unity of the Mari branch combined with its remoteness from the other languages poses formidable challenges for the reconstruction of any grammatical one-phoneme suffix without obvious cognates in other languages. On the other hand, neither the mutual relations of the illative and lative nor the peculiar characteristics of the latter have ever played a decisive role in pursuit of the common origins of the $s$-cases in all four branches, and for this reason the puzzle of the Mari lative will remain detached from the main focus of this study, too. 
As for the $s$-cases in Tables 2 and 3 , all of them have a vast number of other, non-spatial functions in all languages, but they are unanimously regarded as secondary developments of quite ordinary local cases with originally - and still primarily - spatial functions. In other words, the possessive functions of Saami local cases such as the South Saami illative Jaahkese (vedtedh) '(give) to Jaahke' and elative Jaahkeste (åadtjodh) '(get) from Jaahke' are obviously secondary ${ }^{6}$, and the same can be said of the instrumental use of the Erzya inessive (ardoms) mašinaso '(go) by car' as well as the elative arguments of Finnish pitää 'like; hold' (e.g. pitää kahvista 'like coffee', pitää kahvasta 'hold the handle').

\subsection{On the so-called internal and external local cases}

Before delving into the research history of the $s$-cases in more detail, it is important to draw attention to the label "internal local cases" with which these cases are often characterized. The label is usually used in connection with the s-cases in Finnish (sisäpaikallissijat), Estonian (sisekohakäänded) and other Finnic languages (e.g. Russian внутреннеместные nадежu). The ultimate reason for such a concept seems to be the existence of the so-called external local cases (ulkopaikallissijat, väliskohakäänded, внешнеместные падежи), $l$-cases, in all Finnic languages except Livonian (Table 4).

\begin{tabular}{|c|c|c|}
\hline $\begin{array}{l}\text { Source } \\
\text { ('from') }\end{array}$ & $\begin{array}{l}\text { Location } \\
\text { ('at') }\end{array}$ & $\begin{array}{l}\text { Direction } \\
\text { ('to') }\end{array}$ \\
\hline $\begin{array}{l}\text { elative } \\
\text {-sta, -stä } \\
\text { tule-sta 'from the fire' } \\
\text { käde-stä 'from the hand' }\end{array}$ & $\begin{array}{l}\text { inessive } \\
-s s a,-s s a ̈ \\
\text { tule-ssa 'in the fire' } \\
\text { käde-ssä 'in the hand' }\end{array}$ & $\begin{array}{l}\text { illative } \\
-(h) V n,- \text { seen } \\
\text { tule-(h)en '(in)to the fire' } \\
\text { käte-(h)en '(in) } \\
\text { to the hand' }\end{array}$ \\
\hline $\begin{array}{l}\text { ablative } \\
\text {-lta, -ltä } \\
\text { tule-lta 'off the fire' } \\
\text { käde-ltä 'off the hand' }\end{array}$ & $\begin{array}{l}\text { adessive } \\
\text {-lla,-llä } \\
\text { tule-lla 'on the fire' } \\
\text { käde-llä 'on the hand' }\end{array}$ & $\begin{array}{l}\text { allative } \\
\text {-lle } \\
\text { tule-lle 'onto the fire' } \\
\text { käde-lle 'onto the hand' }\end{array}$ \\
\hline
\end{tabular}

Table 4: The so-called internal and external local cases in Finnish exemplified with the words for 'fire' and 'hand; arm' (cf. Table 1 above) 
The term "external local cases" is quite unproblematic in referring to the primary functions of the $l$-cases that prototypically express 'external locality' or, more specifically and more originally - especially when the referent of the noun has a salient surface - 'location on the upper surface'. However, the term "internal local cases" is more of a misnomer, as the $s$-cases do not only signify an 'internal locality' or 'location in the interior of' something, but instead, the $s$-cases can be seen as a semantically unmarked set of local cases (cf. also Finnish inessives maassa 'on the ground', pöydässä 'at the table' selässä 'on one's back'; for more detailed descriptions of the semantics of the local cases in Finnish, see e.g. Leino et al. 1990 and Huumo \& Ojutkangas 2006). True, the later emergence of the $l$-cases in Proto-Finnic and the gradual expansion of their functions may have restricted some of the functions of the more original $s$-cases in a way that they have a slightly less general - and more internal - spatial meaning in Finnic in comparison to other western Uralic languages with $s$-cases. For example, while the Finnish inessive järve-ssä of järvi 'lake' predominantly refers to the location in which fish swim, the adessive järve-llä is used to refer to the location in which swans are swimming or people are sailing or camping, for example. Although Saami, Mordvin and Mari often resort to postpositional phrases to express the meanings 'on' or 'at the vicinity of', the s-cases - such as in the inessives jaevre-sne (South Saami), erke-se (Erzya) and jerô-šte (East Mari) for 'lake' - may also be used in similar contexts (Bartens 1978). In other words, the so-called $s$-cases are simply the primary and nearly only local cases in Saami, Mordvin and Mari, and the label "internal local cases" is somewhat misleading in Finnic linguistics, too.

\subsection{Summary}

Both synchronic and diachronic research on western Uralic local cases have mainly focused on Finnic and Saami languages. In Finnic linguistics, the $s$-cases are usually seen as part of larger systems of local cases. Both Finnic and Saami linguistics are deeply rooted in the Finnish study of Uralic languages, and against this background it is understandable that the Saami case system has been described from a Finno-centric perspective for about two centuries (e.g., Rask 1832: 33-62; Friis 1856: 27-41). On the other hand, both the Saami and Finnic branches, with about ten individual 
languages each, exhibit considerable internal variation that has facilitated a fairly unanimous reconstruction of the Proto-Saami and Proto-Finnic local case systems (see, e.g., Laanest 1975: 102-106; Korhonen 1981a: 216224; Sammallahti 1998: 66-69, 203-211). Furthermore, it is held to be selfevident that whatever the ultimate origins of the Saami and Finnic s-cases are, they seem to stem from a common source, as the reconstructed case markers are virtually identical for Proto-Saami and Proto-Finnic (Tables 2 and 3). The relation of the Saami and Finnic s-cases to those of Mordvin is less straightforward, but at least the forms and functions of the elative forms such as South Saami dålle-ste, Finnish tule-sta and Erzya tol-sto, all meaning 'from the fire', leave little room for guessing. On the other hand, the Mordvin inessive and illative cannot be firmly reconstructed to fully match their namesakes in Saami and Finnic. Mari, in turn, is clearly an outlier in comparison to the three westernmost branches, but it still seems easier to regard the Mari inessive in -šte as a somewhat expected cognate of the Saami and Finnic inessives instead of that of Mordvin. In general, neither Mordvin nor Mari allow as deep internal reconstructions as Saami and Finnic do.

Before commencing with the research history of the $s$-cases in particular (Section 3), it must be emphasized that the $s$-cases have been generally regarded as western Uralic innovations ever since the advent of historical Uralistics. Even though reconstructions of Proto-Uralic case systems differ especially with respect to the number and identity of directional cases, the locative marker ${ }^{*}$-na and the ablative in ${ }^{*}$-ta (or ${ }^{*}$-to or ${ }^{*}$-ti) are actually among the most compelling and most commonly accepted tenets of Uralic historical morphology. The most important proof of the originality of these suffixes is the existence of postpositions and adverbs based on relational spatial nouns such as *ül(i)- 'location on/above' as also manifested in the western Uralic, e.g. Aanaar (Inari) Saami alne 'on, off' $\left(<{ }^{\star} \ddot{u} l(i)-n \ddot{a}\right.$ [on-LOC]), North Saami alde id. (<* ${ }^{*} l(i)-t a ̈$ [on-ABL])); Finnish yllä 'above'

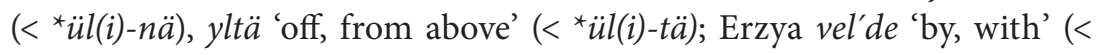
$\left.{ }^{*} \ddot{u} l(i)-t \ddot{a}\right)$ and West Mari $\beta$ lnə 'on' ( $\left.<{ }^{*} \ddot{u} l(i)-n a ̈\right)$. Examples (5a-c) illustrate that the division of labor between the $s$-cases (for ordinary nouns) and apparently more original local cases (for relational nouns) is rather similar from the westernmost Saami to the Mari languages in the east. 
(5) South Saami (Jupmele sjugnede, p. 28 [John 1:1])

$\begin{array}{llllll}\text { a. Aalkovisnie } & \text { Baakoe lij } & \text { jïh Baakoe } & \text { Jupmelen } \\ \text { beginning.INE } & \text { Word } & \text { be.PST.3sg and Word } & \text { God.gen } \\ \text { luvnie. } & \text { Baakoe } & \text { Jupmele lij. } & & \\ \text { in.the.vicinity } & \text { Word } & \text { God } & \text { be.PST.3SG } & \end{array}$

Finnish (Raamattu: John 1:1)

$\begin{array}{llllll}\text { b. Alussa } & \text { oli } & \text { Sana. } & \text { Sana } & \text { oli } & \text { Jumalan } \\ \text { beginning.INE } & \text { be.PST.3SG Word } & \text { Word } & \text { be.PST.3SG } & \text { God.GEN } \\ \text { luona, } & \text { ja } & \text { Sana } & \text { oli } & \text { Jumala. } & \\ \text { in.the.vicinity } & \text { and } & \text { Word } & \text { be.PST.3SG } & \text { God }\end{array}$

West Mari (USo: John 1:1)

c. Т Тйнгӓлтӥцийцтӥ̈ Шамак ылын. Шамак Йымы доно ылын, дӓ Шамак Йымы ылын.

$\begin{array}{lllll}\text { Tongältəšวštə } & \text { Šamak } & \text { âlân. } & \text { Šamak Jâmâ dono } \\ \text { beginning.INE } & \text { Word } & \text { be.PST2.3SG } & \text { Word God in.the.vicinity }\end{array}$ âlân, dä Šamak Jâmâ âlân. be.PST2.3SG and Word God be.PsT2.3SG

'In the beginning there was the Word, and the Word was with (at) God, and the Word was God.'

As regards later developments such as the $s$-cases in western Uralic, or the $l$-cases in Finnic and Permic or the secondary local case markers with the elements ${ }^{*}-k \partial$ - and ${ }^{\star}-n t \partial$ - in Samoyed (see Section 5), the Uralistic tradition labels secondary elements like ${ }^{\star}-s-,{ }^{\star}-l-,{ }^{\star}-k \partial-$ and ${ }^{\star}-n t z-$ as "coaffixes". Thus, the present study is mostly an attempt to find out whether it is possible to understand the origins of the western Uralic coaffix ${ }^{*}-s$-. In principle, it would be desirable for such an attempt to be based on empirical comparative data about the actual use of $s$-cases and their functional equivalents in other languages. Although such approaches are rather foreign to traditional Uralistics, it is precisely this kind of empirical research that has recently unveiled the origins of the Finnic l-cases (Aikio \& Ylikoski 2007; forthcoming) and the so-called dative-genitive in Old Literary Finnish (Inaba 2015). However, as shortly described above, the $s$-cases except for the Mari lative - must be considered the default local cases in all four branches, and this seems to reduce the meaningfulness of meticulous comparisons. In fact, it appears that previous scholars have taken the func- 
tional uniformity of $s$-cases for granted to the extent that even the above remarks on the minor differences between the cases in question greatly exceed those presented in earlier studies on the origins of these cases. (Cf. also the cross-linguistically expected temporal extension of the functions of the inessives in examples $(5 \mathrm{a}-\mathrm{c})$ above.)

\section{History of research}

\section{I. Prehistory (before 1890)}

The scientific study of $s$-cases and their origins dates back to the first half of the 19th century. Sjögren (1828: 393-394, 397-398), Rask (1832: 35ff.) and Castrén (1839: 60-62) already paid attention to the striking similarity between the Finnish inessive, elative and illative cases and their Saami counterparts. In his grammar of Komi, Castrén (1844: 20, 22) also briefly compared the Komi illative and inessive with those of Finnic, and similar observations were made by Castrén (1845: 11) for Mari. However, the first concrete hypothesis concerning the origins of $s$-cases was presented by Lönnrot (1841: 36-37), who did not even mention Saami at all. Instead, through rather unscientific internal reconstruction, he suggested that the Finnish $s$-cases contained an "extra syllable" $s i$ which is supposedly cognate to the relational noun sisä- 'interior' (cf. the later term sisäpaikallissijat 'internal local cases'; on the early history of the description of Finnish local cases, see Stipa 1990: 271-274).

Lönnrot's suggestion was later supported by scholars such as Ahlqvist (1863: 26-27), Hunfalvy (1864: 301) and Blomstedt (1869: 44-45), but it was not until Budenz (1879: 35-36) and Donner (1879: 77-82) that the Finnic $s$-cases were compared with the Mordvin and Mari cases discussed above. At the same time, the comparison was extended further east: to the Permic elative, inessive and illative, and all the way to certain adverbs in Khanty and Hungarian (Donner 1879: 78-82), but these early comparativists did not try to explain the ultimate origins of the suffixes. Apparently the first scholar both to compare Finnic cases with other (Saami) s-cases and to compare the coaffix with some other elements was Weske (1884: 88-89), who claimed that the inessive ${ }^{*}$-sna goes back to ${ }^{*}$-sana $\left(<{ }^{*}-s a+-n a\right)$, in which the element ${ }^{*}-s a$ is identical to that found in denominal adjectives like Estonian ilusa (genitive of ilus 'beautiful' $\leftarrow$ ilu 'beauty') and rõomsa (genitive of rõómus 'joyful' $\leftarrow$ rõõm 'joy'). 


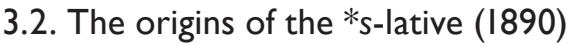

A fundamental turning point in the historical morphology of Finnic languages was in 1890, when both Arvi Jännes (Arvid Genetz) and E. N. Setälä published their professorial theses to qualify for the professorship of the Finnish language and literature at the University of Helsinki. In his thesis on the so-called particles in Finnish, Jännes (1890: 307ff.) did not focus on the $s$-cases per se, but while discussing directional "particles" (i.e., adverbs and postpositions) such as luokse 'to (the vicinity of)' and taakse 'to the behind' on the one hand, and alas 'downward', ulos 'to the outside' and ylös 'upward' on the other, he questioned the previous view according to which the elements - $k s e$ and $-s-$ as well as the so-called final aspiration (i.e., a trigger of a morphophonological process of consonant doubling) in luo ( luokse) and taa ( taakse) - shared a common origin in $\left(^{*}\right)-k s e$, which had quite randomly eroded in two different ways. Instead, Jännes compared adverbs ending in $-s$ with the Saami illative as well as with some directional adverbs in Permic, and concluded that this might justify an assumption that at least the Finnic adverbs and Saami illative go back to a directional suffix ${ }^{*}-s$. This hypothesis was not directly related to the Finnic $s$-cases which he did not want to discuss any further, except for commenting (id.314) that the Finnic illative (Finnish $-h V n$, -seen) seems to consist of "the internal locality marker -se (sese)" followed by a directional suffix ${ }^{*}-n$ and perhaps also ${ }^{*}-k$. In other words, he did not comment at all on Budenz (1879) and Donner's (1879) proposals to relate the Saami and Finnic s-cases to similar elements in Mordvin, Mari and further in the east.

Interestingly, Jännes' proposals were largely reintroduced later in the same year by Setälä (1890: 167ff., 410ff.) in his competing thesis on Finnic historical phonology. He, too, reinterpreted adverbs such as alas 'downward' and ulos 'to the outside' as being separate from the element $-k s(i)$ and related them to the Saami illative, but in addition to Jännes, he also related the element $-s$ to Saami directional adverbs such as North Saami olggos 'to the outside' ( Finnish ulos) as well as to the Mordvin illative in -s. Furthermore, he regarded the same element as the most original "lative" (i.e., directional) case marker that had become the basic component of the Finnic internal local cases, and ultimately laid the fundament of the present-day received view by relating all Saami and Finnic s-cases to those in Mordvin and Mari (Setälä 1890: 410-411).

Although Setälä's thoughts about the $s$-cases are rather dispersed and his chronology of the emergence of $s$-cases and $l$-cases is opposite to that of 
later scholars ${ }^{8}$, it is evident that he sees the ultimate origin of the $s$-cases in the lative in ${ }^{*}-s$ followed by the most original Uralic local case markers: inessive ${ }^{*}$-sna is seen as a combination of the lative ${ }^{*}-s$ and locative ${ }^{*}-n a$, and the elative - sta as that of ${ }^{\star}-s$ and ablative ${ }^{\star}$-ta. The latter part of the illative ${ }^{\star}$-sen is characterized as "some kind of directional suffix". ${ }^{9}$ Incidentally, Setälä did not explicate the corresponding relation of the Finnic elative to its namesakes in Saami and Mordvin, but it is obvious that these analogous suffixes have not gone unnoticed from him, and there is little reason to doubt that he did not regard these elements as full cognates in comparison to the less compatible inessives in the four branches.

Setälä's autocratic way of leading and misleading Finnish linguistics in the early 2oth century is well known (see, e.g., Vares \& Häkkinen 2001: 259-283). When it comes to the present discussion, it may appear that he should also have been criticized for his bold conjectures about the origin of the western Uralic s-cases. However, it must be admitted that while Setälä was unusually bold and paid barely any attention to the plausibility of his suggestions from the functional point of view, he was not reckless but instead very cautious about the preliminary nature of his hypotheses. For example, while suggesting that the Mordvin inessive marker -so goes back to the geminated ${ }^{*}-s s V$ and ultimately to ${ }^{*}-s n V$, he confessed that he had no proof for his claim:

Suoranaisia todisteita ei meillä tietääkseni ole siitä, että pitkä $s$ olisi syntynyt alkupe-

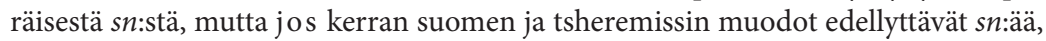
niin on varmaan samoin mordvalaisten laita. (Setälä 1890: 410-411)

'As far as I know, we do not have actual evidence for the development of the long $s$ from an original $s n$, but since the Finnish and Mari forms happen to presuppose $s n$, then probably the same must apply to Mordvin.'

All in all, Setälä presented many of his "ideas" and "opinions" by "assuming" how the $s$-cases have "perhaps", "possibly" and "maybe" developed. He himself is not directly responsible for the fact that his cautious wordings were forgotten and his conjectures soon became canonized dogmas that have mostly remained unproved and undisputed (cf. Vares \& Häkkinen 2001: 263-264). Setälä has also been accused of plagiarism throughout his linguistic career (Karlsson 200o), but when it comes to the origins of the $s$-cases, Setälä (1890) - quite unlike many of his predecessors as well as successors - diligently referred to earlier scholars and their contribution to his thinking. As regards Jännes' (1890) brand-new thesis with its surpris- 
ingly similar ideas, Setälä (1890: 171) added a footnote in which he defends himself against possible accusations of plagiarism by telling that in the very final stages of typesetting he had received a copy of Jännes' study that could not have influenced his own argumentation and proposals that also differ from those of his rival.

\subsection{The canonization of the *s-lative (after 1890)}

After 1890, Setälä's hypotheses concerning the ${ }^{*}$ s-lative (> Finnic intervocalic $h$, Mari $\check{s}$ ) and its role in the development of the western Uralic scases were soon adopted to the extent that nearly all textbooks as well as seemingly more original studies on the topic have been content to repeat Setälä's original claims with only little modifications. In truth, the most important modification to Setälä's proposals is the nonchalant omission of his original cautiousness, as witnessed by Szinnyei's (1910: 78-80; 1922: 66-68) subsequent statements about the origins of the "non-Ugric", i.e. Finno-Permic inessive, elative and illative:

Inessiv, Elativ, Illativ.

(Nicht-ugrisch.)

Diesen Kasusformen liegt der Lativ auf -s (mit einem vorderen Vokal) zugrunde. Aus diesem ist zuerst als pleonastische Kasusform der Illativ entstanden, und nachdem man den ihm zugrunde liegenden Lativ als Stamm betrachtete, haben sich auch die beiden anderen Glieder dieser Gruppe herausgebildet. (Szinnyei 1910: 78)

Inessiv, Elativ, Illativ.

Finnisch-permisch.

Diesen Kasusformen liegt der Lativ auf ${ }^{{ }_{-}} s \sim^{{ }^{*}}-z$ (mit einem vorderen Vokal) $\mathrm{zu}-$ grunde. Aus diesem ist zuerst als spezialisierter Kasus der Illativ entstanden, und nachdem man den ihm zugrunde liegenden Lativ als Stamm auffaßte, haben sich auch die beiden anderen Glieder dieser Gruppe herausgebildet. (Szinnyei 1922: 66)

From Szinnyei (1910, 1922) on, Jännes and Setälä's view were amalgamated into a general theory of and ultimately the received view on the origins of the $s$-cases. When Setälä (1890: 410-412) explained the Finnish elative $(-s-t a)$, inessive $\left({ }^{*}-s-n a\right)$ and illative $\left({ }^{*}-s e-n\right)$ as combinations of the ${ }^{*} s$-lative and other local case markers, he did not at all mention the Mari illative in -ške which, by contrast, was mentioned by Jännes (1890: 310; see also Szinnyei 1910: 80), who regarded the latter part of the suffix as a lative in ${ }^{\star}-k$. 
All these explanations were gradually presented as one - hereafter referred to as the "lative theory" - by scholars such as Ravila (1935: 45-47), Ariste (1954: 45-46) and their followers, while researchers of Mari follow Jännes (1890) with one mind in describing the Mari illative as a result of the same kind of case stacking as those suggested by Setälä for Saami, Finnic and Mordvin: a combination of the lative in ${ }^{*}-s\left(>-s^{-}\right)$and another in ${ }^{*}-k(V)$ (see, e.g., Beke 1911: 191; Galkin 1964: 21; Alhoniemi 1967: 326ff.; Bereczki 1988: 343; Anduganov 1991: 81). ${ }^{10}$

As a whole, about the only points of disagreement have been the relative chronology of the western Uralic s-case suffixes, and the question on whether $s$-cases can also be found in the Permic languages. According to Szinnyei, the first amalgamated $s$-case was the illative (lative ${ }^{\star}-s+$ lative ${ }^{*}-n$ ) - first characterized as pleonastic (Szinnyei 1910) and later as “specialized" (Szinnyei 1922) - but according to later scholars (e.g., Ravila 1935: 46-47; Hakulinen 1941: 89; 1979: 103; Korhonen 1975: 115-116; 1979: 14),

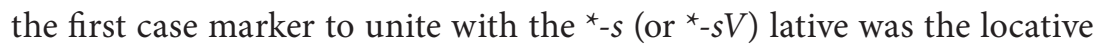
in ${ }^{*}$-na (in the common proto-language of Saami, Finnic, Mordvin and Mari), followed by the ablative in ${ }^{*}-t a$ and only after that by latives in ${ }^{*}-n$ and ${ }^{\star}-k$ (Table 5 ).

\begin{tabular}{|c|c|c|c|c|}
\hline & Saami & Finnic & Mordvin & Mari \\
\hline inessive & ${ }^{*}-s n a$ & ${ }^{*}-s n a$ & ${ }^{*}-s n a$ & ${ }^{*}-s n a$ \\
\hline elative & ${ }^{*}$-sta & ${ }^{*}$-sta & ${ }^{*}$-sta & - \\
\hline illatives & ${ }^{*}-s V n$ & ${ }^{*}-s V n$ & - & ${ }^{*}-s k V$ \\
\hline
\end{tabular}

Table 5: The relative chronology of the amalgamation of the new $s$-cases according to Korhonen (1975: 115-116)

As regards Szinnyei's hypothesis about the Proto-Permic origins of the $s$ cases, it rests solely on the existence of the elative cases in -iś (Komi and Udmurt; in Udmurt -isśt- before possessive suffixes) and -iś(Permyak), as well as analogous ablative markers preceded by $-l$-. This assertion was soon rejected by Wichmann (1923-1924: 162-163), who stated that the palatalized ś in Permic cannot correspond to the unpalatalized $s$ in the west, and this argument has been favored by most scholars ever since (see, e.g., Collinder 1962: 160; Erkki Itkonen 1966a: 274-275; Bartens 2000: 85). Otherwise, it is particularly striking that especially Finnish scholars have, almost without exception, presented the theory of the origins of the $s$-cases as an undeniable fact: 
On täysi syy katsoa, että suomalais-volgalaisten kielten sisäpaikallissijain tunnus $s$ (> tšer. $\check{s}$ ) on syntynyt juuri puheena olevasta latiivisuffiksista. Tätä mieltä ovat olleet mm. Setälä, ÄH 168, Szinnyei FUS² 66, Toivonen FUF XXVIII 14, Ariste, mts. 46, Serebrennikov Osnovnye linii razvitija padežnoj i glagol'noj sistem v ural'skih jazykah 26, epäröiden RAVILA FUF XXIII 45-46 ja HAKULINEN SKRK² 94. (Erkki Itkonen 1966a: 273)

'There is every reason to believe that the Finno-Volgaic internal local case marker $s$ (> Mari $\check{s}$ ) has developed from the lative suffix in question. This has been the opinion of, inter alia, [Setälä (1890: 168), Szinnyei (1922: 66), Toivonen (1944: 14), Ariste (1954: 46), Serebrennikov (1964: 26)], and with some hesitation [Ravila (1935: 45-46) and Hakulinen (1961: 94)]'.

For more recent expressions of the same faith, see, for example, Korhonen (1975; 1979: 13-14), Bartens (1999: 78); Leino (2001: 496-497), Huumo and Ojutkangas (2006: 17) and Lehtinen (2007: 77-80) as well as the discussion in Section 4 below.

From 1890 on, the Finnic-Mordvin translative in $-k s(i)$ also got drawn into the discussion on the remnants of the ${ }^{*} s$-lative, but as the speculations about the combination of the latives in ${ }^{*}-k$ and ${ }^{*}-s$ (originally presented by Szinnyei 1910: 77 and still supported by, e.g., Korhonen 1979: 10-11; Riese 1993 and Grünthal 2003: 186) have been gradually discredited in favor of more plausible explanations, the translative suffixes fall outside the scope of this study (see, e.g., Janhunen 1989; Saarinen 2001; Ajanki 2014; Salminen 2014). In his investigation of the Mari illative in $-\check{s}(k e)$ and lative in -(e)̌́, Alhoniemi (1967: 323-338) also presents a detailed attempt to shed light on their origins and later development, but the complex inter relations of these two cases at the outskirts of the otherwise more uniform $s$-cases still remain too obscure to be reappraised within the confines of the present study (cf. Section 5.2).

\subsection{Alternative hypotheses and their reception}

In spite of the apparent consensus on the origins of the s-cases, not all scholars have been content with the hypotheses based on a lative in ${ }^{*}$-s. However, it is surprising to see how little the supporters and critics of the lative theory have actually referred to each other. Instead, the relations of these two groups - and the interrelations of the latter group - are largely characterized by disregard for each other's publications. Most nonconformists have resided and published their thoughts outside Finland and 
Helsinki in particular: Wiklund (1927), Collinder (1952, 1962) and Tauli (1956) mainly in Sweden, Átányi (1941) in Hungary and Bubrih (1946) in the Soviet Union, and in Finland, K. Häkkinen $(1983,1984,2002)$ and Alhoniemi $(1988,2001)$ in Turku.

To present a short overview of alternative hypotheses, the following main lines can be identified. Perhaps not very surprisingly, the first opponent of Setälä's hypothesis was his famous antagonist K. B. Wiklund, who, in his 1927 paper on the origins of the translative markers in Finnic $(-k s i,-k s e-)$ and Mordvin ( $-k s)$, refuted Setälä's claims on the relations of the directional $-s$ adverbs and the $s$-cases in Saami and Finnic by referring to mismatches in consonant gradation. However, the only thing Wiklund seems to have said about his own thinking concerning the origins of the $s$-cases are the following enigmatic words:

Mi hát ez az -s, amely a belső helyi esetek ragjainak közös kezdőhangja, és milyen jelentéssel ruházta fel őket kezdettől fogva? Azt hiszem, legalább második kérdésre elég nagy valószínüséggel megfelelhetünk, but that is another story, ahogy Kipling mondaná. (Wiklund 1927: 328)

'What, then, is the $-s$, which is the common initial sound of the internal local cases, and what meaning did it give them in the beginning? I think that we are able to answer at least the second question with high probability, but that is another story, as Kipling would say'.

After Wiklund's death in 1934, Átányi (1941: 350-351) referred to Björn Collinder, according to whom Wiklund had proposed in his lectures that the element in question originated from a determinate element of some kind. Átányi himself seems to doubt such an explanation and points out that a determinate element would have been more plausible after, instead of before, the most original local case markers. However, a similar hypothesis was soon put forward by Bubrih (1946), who was more explicit in connecting the $s$-cases with the use of the postpositional element $e(j) s$, $e z$ - in the periphrastic equivalents of the definite declensions in Mordvin (Table 6).

Bubrih's wordy proposal - later summarized and repeated in his monographs on the historical morphology of Erzya (Bubrih 1953) and Finnish (Bubrih 1955) - was soon commented on and dismissed by Ariste (1954), and indeed, his conjectures contain few arguments that would merit serious evaluation. Bubrih's thoughts are also mentioned and abandoned in Galkin (1964: 21) and Anduganov's (1991: 78) accounts on the history of 
Jussi Ylikoski

\begin{tabular}{l|lll} 
& Elative & Inessive & Illative \\
\hline $\begin{array}{l}\text { Indefinite } \\
\text { case forms }\end{array}$ & moda-sto & moda-so & moda-s \\
$\begin{array}{l}\text { Definite case } \\
\text { forms }\end{array}$ & moda-stońt' & moda-sońt' & moda-ńn' en $^{11}$ \\
$\begin{array}{l}\text { Postpositional } \\
\text { phrases }\end{array}$ & moda-ńt' ejste & moda-ńt' ejse & moda-ńt' ejs \\
\hline
\end{tabular}

Table 6: Erzya s-cases and their definite counterparts as exemplified with moda 'earth, ground'

Mari, but it is striking that western scholars seem to have never even mentioned this hypothesis since Ariste.

Another type of alternative explanation for the $s$-cases does not refer to definiteness or other clear semantic categories, but more vaguely to the element - $h$ - in Finnic and - $s$ - in Saami denominal adjectives such as Finnish sija(h)inen 'substitute, deputy' $\longleftarrow$ sija 'place' and North Saami sadjásaš $\leftarrow$ sadji id. These examples are given by Collinder (1952: 11; 1960: 291-292; 1962: 159), who does not even mention the mainstream view in his general surveys of the Uralic comparative grammar. In fact, these kinds of comparisons had been occasionally presented since Aminoff (1871: 256-257) and Ahlqvist (1877: 64), but Collinder's full disregard of the prevalent lative theory must certainly be interpreted as a statement of distrust towards it. A much more explicit expression of distrust is, however, presented in Tauli's (1956: 206-207) article on the origins of Uralic affixes in which he acknowledges the existence and popularity of the lative theory, but questions its credibility (p. 207): "Opinions differ as to the process by which the lative $-n$, the locative $-(n) a$ and the ablative $-t(a)$ were added to this element, and it is, in fact, difficult to find an explanation to this."12 Tauli carefully refers to his predecessors such as Ravila (1935: 45-47), but points out that the lative theory needs a justification and regrets that no functional explanation has been given. As a solution to this deficiency Tauli goes on to present his own, admittedly vague explanation:

It is obvious that at the time when the locative suffix - na and the ablative suffix - $t a$ were added to the suffix -s the latter could not have lative function, but it had either the function of a general local case or it was conceived as belonging to the stem. Since there is no foundation for the first assumption, then it is more natural to assume that at the time when the internal local cases sprang into existence, the $-s$ suffix occurred as an element of the stem, i.e. as a derivational suffix. (Tauli 1956: 207-208) 
Tauli also refers to the above-mentioned thoughts of Collinder (1952), but both critics have been largely ignored ever since (but see Erkki Itkonen 1966a: 273; Rédei 1996: 258). Finally, similar thoughts have been also presented by Alhoniemi (2001: 111-113), who parenthetically refers to Collinder (1960: 291-292), but otherwise develops his own ideas about the vaguely spatial yet originally non-directional function of the element $s$ in the $s$-cases. His own proposal - preliminarily presented in Alhoniemi (1988: 34) - is rather approximate and undecided, however:

Nehmen wir einmal an, daß die alten Wo- und Woher-Kasusformen der ${ }^{\star} s(?<$ $\left.{ }^{*}-k s V\right)$-Ableitungen im Bewußtsein von drei Morphemen auf zwei Morpheme übergegangen wären, also in der Art Stammwort $+{ }^{*}-s$-Ableitungssuffix $+{ }^{*}-n A$-Kasusendung $>$ Stammwort $+{ }^{\star}-s n A$. Die Form mit dem bloßen Ableitungssuffix hätte man dann vielleicht aufgrund des Systemzwangs als Wohin-Kasus aufgefaßt, also als -s-Lativ.

Ein solcher Gedankengang ist natürlich völlig hypothetisch. Es bleibt die Aufgabe der Forschung, endgültig zu klären, ob das Lativ-* $s$ möglicherweise auf ein Ableitungssuffix zurückgeht. (Alhoniemi 2001: 113)

In the following sections, I attempt to scrutinize whether the element -s can really go back to a directional case marker and what can - and must be said about the ultimate origin of this element.

\section{Critical evaluation of the received view}

\section{I. Lative cases as deus ex machina}

The origins of the $s$-cases aroused the interest of linguists already before the similarity of the Saami, Finnic, Mordvin and Mari local case markers was systematically recorded by comparative Uralists in the late 19th century. The research history of the origins of the $s$-cases can be easily divided into periods before and after the emergence of the idea of the lative case in *-s (Jännes 1890, Setälä 1890). However, the 20 th century witnessed not only the canonification of what can be termed the "lative theory", but also intermittent attempts to challenge the received view. Interestingly, the challengers of the mainstream have been rather modest in advocating their own views: In spite of various alternative proposals, only Wiklund (1927) and Tauli (1956) have expressedly stated that they doubt the lative theory on phonological and semantic grounds, respectively. In the recent decades, 
only K. Häkkinen (1983: 74; 1984: 9; 2002: 80) seems to have unpretentiously pointed out that the lative theory suffers from unsolved chronological and semantic problems:

Vaikka $s$-sijasysteemi näyttääkin olevan selvästi suomalais-volgalainen innovaatio, ei sen syntyyn liittyviä ongelmia ole lopullisesti ratkaistu. Sukukielten vastineiden puuttumisen perusteella täytyy koko $s$-latiivi katsoa suomalais-volgalaiseksi uudennokseksi. Suomalais-volgalaisen kauden arvellaan kuitenkin olleen melko lyhyt (...), mutta silti on oletettava s-päätteen, jonka alkuperää toistaiseksi ei ole pystytty selvittämään, tulleen tänä aikana kiinteäksi osaksi sijaparadigmaa, vieläpä sen tunnusmerkittömäksi perussijaksi (ks. tarkemmin Korhonen CTIFU I 1970), menettäneen osittain produktiivisen sijapäätteen luonnettaan siten, että sen pohjalta on voitu muodostaa myös uusia sijoja. (K. Häkkinen 1983: 74)

'Although the system of $s$-cases clearly seems to be a Finno-Volgaic innovation, problems related to their emergence have not been finally resolved. Due to the absence of cognates in other related languages, the ${ }^{*} s$-lative as a whole must be regarded as a Finno-Volgaic innovation. The Finno-Volgaic period, however, is assumed to have been quite short (...), but one nevertheless has to assume that during this period, the suffix $-s$, the origins of which have remained unresolved to date, became an integral part of the case paradigm, even an unmarked basic case (for more details, see Korhonen [1975]), and partly lost its original nature as a case marker, so as to serve as a basis for the development of new cases.'

Koko pääteryhmän historiallisen alkuperän selvittämistä vaikeuttaa se, että ${ }^{*}$-s-latiivin alkuperä on tuntematon. Sille ei ole pystytty osoittamaan sen enempää päätekuin johdinvastineitakaan volgalaiskieliä kauempaa. (K. Häkkinen 2002: 80)

'The exploration of the historical origins of the entire set of these suffixes is complicated by the fact that the ${ }^{*} s$-lative is of unknown origin. It has not been possible to provide evidence for either inflectional or derivational cognates beyond the [Finno-]Volgaic languages.'

As mentioned in Sections 1 and 2.1, the existence and the relative uniformity of the $s$-cases has traditionally been considered a central argument in favor of the Finno-Volgaic affinity. However, the popularity of ProtoFinno-Volgaic and many other intermediate proto-languages has gradually diminished since K. Häkkinen's $(1983,1984)$ reappraisal of the traditional view. As a consequence, the problems of chronology and internal stratification of Finno-Volgaic are potentially much greater than before.

As regards the other, more substantial challenges mentioned in the above quotations, it is important to observe that while the ultimate origin of the ${ }^{*}$-lative has remained unknown, the supporters of the mainstream 
theory have indeed been fully content with the dogma that the $s$-cases simply go back to combinations of a lative case marker ${ }^{*}-s$ and other comparable case markers, whatever the history of the ${ }^{*} s$-lative may otherwise be. ${ }^{13}$ As mentioned by K. Häkkinen (1983: 74), it is true that especially Korhonen (1975; see also 1979) has attempted to relate the later phases of the lative theory model to the contemporary general linguistic understanding of the concepts of markedness and unmarkedness (in the Greenbergian sense). The main point in Korhonen's argumentation is that the directional cases of Uralic languages have a higher frequency, more allomorphy and more subcategories than other local cases, and this feature of "unmarkedness" enables directional cases to serve as an unmarked platform to other case markers - while maintaining their directional meaning at the same time. The latter, diachronically applied part of the notion of unmarkedness seems to be his own invention.

While repeatedly referring to three lative case markers ${ }^{*}-k,{ }^{*}-n$ and ${ }^{*}-j$ ) in Proto-Uralic and Proto-Finno-Ugric (Korhonen 1975: 116; 1979: 2), Korhonen (1979: 13-14) presents the Proto-Finno-Volgaic local case system with three formally distinct lative markers (e.g., ${ }^{\star}$ pes $\ddot{a}-s,{ }^{*}$ pes $\ddot{a}-k$ and ${ }^{\star}$ pes $\ddot{a}$ $n$ [nest-LAT]) without defining their possible semantic differences in any way. When it comes to the backgrounds of these latives, it is more understandable that the ultimate origins of the three alleged Proto-Uralic lative markers are left without further discussion, but it is perplexing to observe that when deliberately discussing the origins and development of the $s$ cases, Korhonen's starting point carries biblical overtones reminiscent of examples $(5 \mathrm{a}-\mathrm{c})$ seen above. His description of the emergence of $s$-cases begins straightforwardly with the following assertion:

“Zunächst gab es den $s$-Lativ (z. B. * pesä-s)." (Korhonen 1979: 14)

'In the beginning was the ${ }^{*}$-lative (e.g. ${ }^{*}$ pesä-s).'

True, it appears that the lative theory (Sections 3.2 and 3.3) lends itself to criticism better than the alternative explanations that have been put forward in even more arbitrary and haphazard manner by a number of scholars who have not even referred to each other (Section 3.4). This said, it is illuminating to depict the major components of the lative theory model in Figure 4.

The received view on the origins of the default local case markers as depicted in Figure 4 is, admittedly, chaotic and dubious. One must agree with Tauli (1956: 207-208) that no explanation has been given, for example, as to "how 
it was possible that the locative suffix was added to a case suffix having lative meaning", especially if the lative suffix can simply be declared to originate in the initial phase of a controversial intermediate proto-language in which the same suffix has allegedly given up at least part of its original meaning. Furthermore, it must be remembered that Figure 4 is only a streamlined version of the classical view, which also embodies the development of the present-day lative case in Mari (see Section 2.2) as well as the Finnic-Mordvin translative (see Sections 3.3 and 5.2), and according to scholars such as Korhonen (1975: 116; 1979: 2), the Proto-Uralic lative forms ${ }^{\star} t u l i-k$ and ${ }^{\star} t u l i-n$ are supposed to have been accompanied by one in ${ }^{\star}-j$, i.e. ${ }^{\star} t u l i-j$ (cf. also Note 13 ).

As far as the model depicted by Figure 4 must be regarded as the commonly accepted explanation for the origins of the $s$-cases, the following comments are in order. As already noted, the popularity of this model seems to result from the partly unconscious canonization of Setälä (1890), who actually presented his proposals very cautiously. Modern historical linguists are supposed to back up at least their most innovative theories with parallels from other languages, but this has never been done for the lative theory, even though the received view scarcely fits our present typological knowledge of attested developments of local cases and other adverbial cases. A very similar example is provided by the fate of Budenz's (1886: 464) cursory hypothesis about the origins of the Finnic $l$-cases: cautiously supported by Setälä (1890: 409), Budenz's conjecture was later presented as an unquestionable truth by Szinnyei (1910: 73-75), and remained as such for a century, until the coaffix *- $l$ - was explained as a reflex of the Proto-Uralic postpositional stem * $\ddot{u} l(i)$ - 'location on/above' instead of a derivational suffix akin to the Finnic oikonym suffix -la (Aikio \& Ylikoski 2007; forthcoming). As regards our typological knowledge about the development of case markers, it suffices to say that the current textbooks of historical linguistics take for granted that case suffixes usually arise from postpositions (e.g. Hopper \& Traugott 2003: 110-111). Although this view does not seem to be based on many comprehensive cross-linguistic studies on the topic, it is nevertheless quite safe to state that this is indeed the case (cf., e.g., Kahr 1976; Heine 2009; Kulikov 2009; Creissels 2009; Ylikoski 2011); I will return to this topic in Section 5 .

To turn back to the concept of "lative" as used in Uralistics, it can be characterized as a kind of deus ex machina that is very often used to explain all kinds of elements - case suffixes, derivational suffixes and more opaque morphological elements - that are too problematic to be viewed as results of regular sound changes (cf., e.g., Aikio \& Ylikoski 2007: 33, 57-60; 
'to the fire' 'in the fire' 'from the fire'

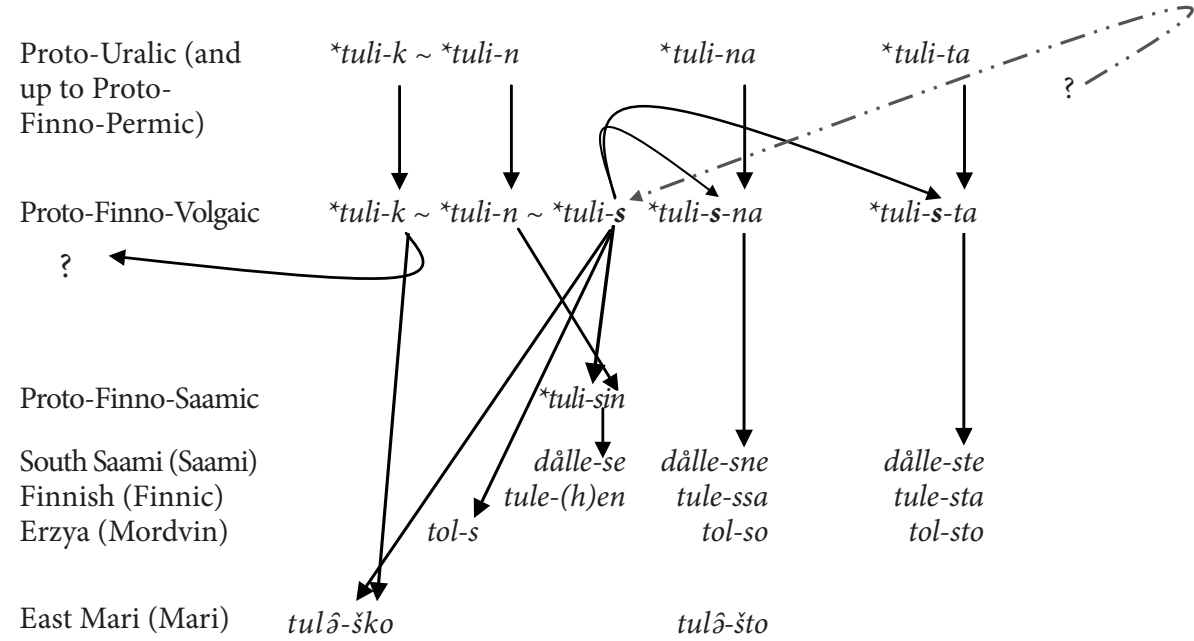

Figure 4: The received view on the development of the default local case markers from Proto-Uralic (and more controversial Proto-Finno-Ugric as well as ProtoFinno-Permic) to the present-day Saami, Finnic, Mordvin and Mari languages

forthcoming; Ylikoski 2011: 255-256, 262-264). As far as the alleged latives are to be understood as directional cases proper, it seems typologically improbable - in light of both the present-day Uralic languages and languages of other families - that any of the earliest proto-languages has had as many as three directional cases (e.g., ${ }^{*}-k,{ }^{*}-n$ and ${ }^{*}-j$ in Proto-Uralic or ${ }^{*}-k$, ${ }^{*}-n$ and ${ }^{*}-s$ in (Pre-)Proto-Finno-Volgaic, not to speak of ${ }^{*}-k,{ }^{*}-n,{ }^{*}-s,{ }^{*}-s V n$, ${ }^{*}$-skV and ${ }^{*}-k s V$ in later stages of Proto-Finno-Volgaic), if the number of other local cases has not exceeded two as is usually unanimously assumed. True, Korhonen $(1975,1979)$ has suggested that some of the variation could be explained by synonymy ascribed to the claimed unmarkedness, but perhaps a more natural explanation for more than one reconstructed directional case would be the division of labor between a directional case proper and a dative case to code recipients, for example (cf. Kittilä \& Ylikoski 2011). This, however, does not seem to solve the puzzle of the $s$-cases in any way. 


\subsection{When case markers are combined}

A specifically prolific and typologically unusual feature of reconstructed Uralic latives is that they tend to amalgamate with other cases without any obvious restrictions. At first glance, combinations such as the lative ${ }^{*_{-}} s$ and the locative ${ }^{*}$-na may invite comparison with phenomena known by names like "case stacking", "case compounding" or Suffixaufnahme (e.g. Plank 1995; Sadler \& Nordlinger 2006; Noonan 2008), but in contemporary Uralic languages, the only truly productive - and typologically expected way of stacking case markers one after another seems to be related to the use of genitive-marked nouns as hosts to other, usually more concrete cases such as the illative in Mari (6) or the elative in Udmurt (7). However, this is quite different from hypothetical "latives" that are claimed to have lost all of their original semantic functions. In purely morphological terms, example (8) from Erzya comes a bit closer to the model depicted in Figure 4 , as the word form vel'estent'eń consists of the noun for 'village' followed by the elative suffix -ste combined with a "lative"-like dative marker -ńt'eń.

East Mari

(6) Шке пашам пытарен, еныныш каят. ${ }^{14}$

Ške pašam pâtaren, jey-ôn-ôš kajat.

own work.ACC finish.CVB.INS stranger-GEN-ILL go.3PL

'After finishing their own work, they go to the one

(= work) of a stranger.' (Alhoniemi 1993: 51)

\section{Udmurt}

(7) Нылпиослы уждун тыронлы Россилэн «кисыьысьтыз» 1 миллион 819 сюрс манет но республикамылэнысьтыз 440 сюрс манет висъяны чакламын.

Nilpiosli uždun ronli Rośśilen «kisiiśtiz» 1

child.PL.DAT salary payment.DAT Russia.GEN pocket.ELA.DEF 1 mil'l'ion 819 śurs mańet no respublika-mi-len-iśt-iz million 819 thousand ruble and republic-1PL-GEN-ELA-DEF 440 śurs mańet visjani čaklamin.

440 thousand ruble separate.INF plan.PST.PTCP.RES ${ }^{15}$

'It has been planned that for the payment of children's salaries, 1,819,000 rubles will be taken from the 'pocket' of Russia, and 444,000 rubles from that of our republic.' (http://www.udmdunne.ru/articles/art1771.html 27.5.2008) 
The origins of the western Uralic s-cases revisited

\section{Erzya}

(8) Кияванть мольсть кавто ломанть. Вейкесь эскельди веленть ёндо, омбоцесь моли веленть ёнов. Велестэнтень максови колоньгеменьшка ие, веленть ёнов молииясь-шержей атя.

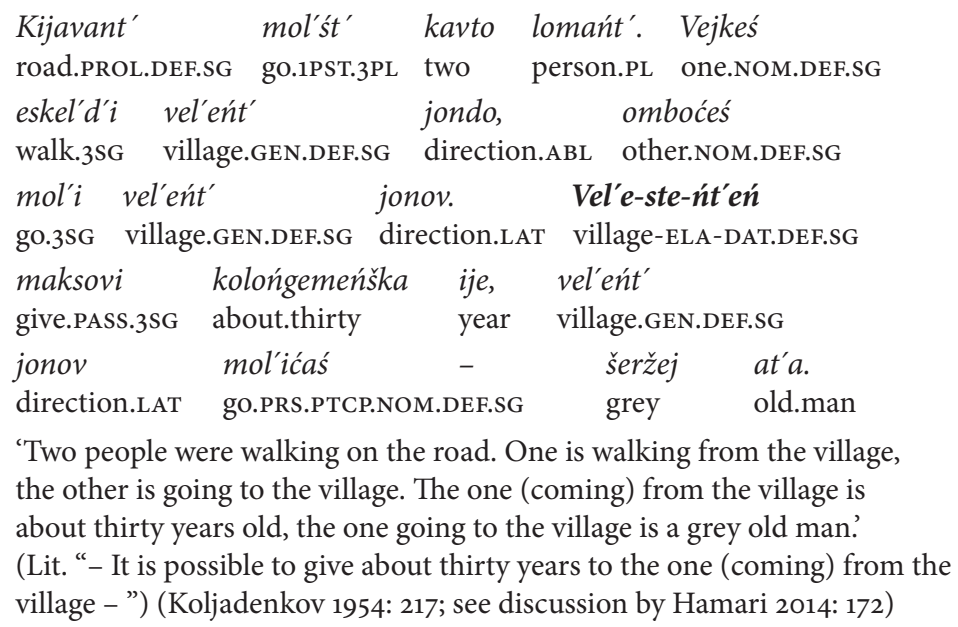

Nevertheless, all the compounded case forms in (6-8) are actually instances in which the first case markers function as derivational suffixes yielding meanings like 'the one of a stranger', 'that of our republic' and 'the one from the village', which in turn are, like ordinary nouns, inflected in grammatical categories such as case and definiteness. As such, they hardly serve as the support the lative theory needs. Occasional references to instances of so-called double declension in Mongolic languages (see, e.g., Janhunen 2003, passim) seem to fit the picture provided by examples (6-8) better than lend support to the theory presented in Figure 4, although further research may be needed. The most systematic cross-linguistic study on the evolution of case systems is presented by Kulikov (2009), and although one of his subtypes of case origins is labeled as "multilayer case marking", in which "[n]ew cases (usually, new locatives) [are] created by adding existing case markers to some case forms or to adverbials with case-like semantics" (p. 445), it is symptomatic that the only clear example of this type consists of the received but dubious view about the origins of Uralic cases such as the $s$-cases.

However, it appears that the relatively recent development of the socalled approximative cases in Komi, albeit quite infrequent in use, might 
provide not only the nearest but also the typologically most relevant support available. Consider the approximative case marker -lan' 'to the direction of' as in stenlan' 'to the direction of, against the wall' (9), also visible in the word forms tijaslanin 'in the direction of the lakes' (10) and Važkurjalańis 'from the direction of Vazhkur"ya' (11) in which the element -lań is followed by the elements -in and -iś that are identical with the inessive and elative suffixes:

Komi

(9) Куйлӧ стенлань бергӧдчӧмӧн.

Kujle śt'enlań bergedćemen.

lie.3SG wall.APPR turn.CVB.INS

'S/he is lying turned towards the wall.' (Kuznetsov 2012: 144)

(10) Ыльс тыясланьын кутісны гыпкыны-лыйсьыныь.

$\begin{array}{llll}\text { Ilis } & \text { tijaslanín } & \text { kutisni } & \text { gipkini-lijśinini. } \\ \text { distant } & \text { lake.PL.APPRINE } & \text { begin.PST.3PL } & \text { pop.INF-shoot.INF }\end{array}$

'Somewhere in the direction of the distant lakes some people began to shoot.' (Kuznetsov 2012: 167)

(11) Тайӧ туйӧдыс татчӧ коркӧ кутшӧмкӧ важ йӧз волӧма

\section{Важкурбяланьысь.}

$\begin{array}{llll}\text { Taje tujędis tatće korke kučemke važ } & \text { vǎn } \\ \text { this } & \text { road.PROL.DEF hither sometimes someone ancient } \\ \text { jezz } & \text { volema } & \text { Važkurjalańiśs. } & \\ \text { people } & \text { arrive.PST2.3SG } & \text { Vazhkur"ya.APPRELA } & \end{array}$

'Some ancient people arrived along this road from the direction Vazhkur"ya. (Kuznetsov 2012: 170 < ÖKK 91-92)'

The development and contemporary use of the Komi approximative cases (Table 7) has been described at length by, e.g., Nekrasova (1990), ÖKK (9193) and Kuznetsov (2012: 140-152, 165-175). What is most relevant here is that as an apparently fully transparent series of local cases, the approximative cases are probably the best if not the only reliable set of local cases that most evidently originate from a directional case marker followed by many different local case suffixes and thus can be interpreted as a parallel that could to some extent support the lative theory with which the $s$-cases have been explained. However, a crucial difference here is the fact that the rather specific meaning of the approximative case has been largely inherited by the 


\begin{tabular}{|c|c|c|}
\hline & & Rough translation \\
\hline $\begin{array}{l}\text { Approximative -lań } \\
\text { + Elative - iśs }\end{array}$ & $=$ Appr.-elative -lańiś & 'from the direction of' \\
\hline $\begin{array}{l}\text { Approximative -lań } \\
\text { + Inessive - in }\end{array}$ & $=$ Appr.-inessive -lańin & 'in the direction of' \\
\hline $\begin{array}{l}\text { Approximative -lań } \\
+ \text { Illative }-e\end{array}$ & = Appr.-elative -lańe & 'to the direction of' \\
\hline $\begin{array}{l}\text { Approximative -lań } \\
\text { + Egressive -śan }\end{array}$ & = Appr.-egressive -lańśan & $\begin{array}{l}\text { 'all the way from the di- } \\
\text { rection of' }\end{array}$ \\
\hline $\begin{array}{l}\text { Approximative -lań } \\
+ \text { Prolatives } 1 \text { and } 2-e d,-t i\end{array}$ & = Appr.-prolative -lańed, -lańti & 'along the direction of' \\
\hline 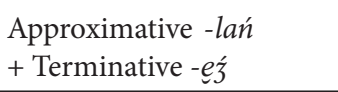 & = Appr.-terminative -lańés & 'up to the direction of' \\
\hline
\end{tabular}

Table 7: The composition of the so-called approximative cases in Komi (ÖKK; Kuznetsov 2012)

entire series, whereas the meaning of the hypothetical Proto-Finno-Volgaic ${ }^{*} s$-lative has never been explained in more specific terms. What is more, the resulting elatives, inessives and illatives (Table 5 ) have become the default local cases in which the coaffix ${ }^{*}$-s- does not have any semantic function of its own. Despite Korhonen's $(1975,1979)$ attempts to explain the situation by referring to the extraordinary "unmarkedness" and concomitant neutrality of Uralic latives, the claimed development of the elative case forms such as South Saami dalleste, Finnish tulesta and Erzya tolsto 'from the fire' from a common form *tuli-s-ta with the most original meaning 'to from the fire' (sic), as well as the inessive form ${ }^{\star}$ tuli-s-na 'to in the fire' (sic) - to name but one of thousands of nouns in any proto-language - still calls for an extraordinarily good explanation that has never been provided. In any case, in light of our current understanding of Uralic and other languages, it seems arbitrary to postulate such development to a proto-language that may never have existed in the first place, and even if it did, the origin of the ${ }^{*} s$-lative itself would need an explanation as well.

Another quite plausible example of "multilayer case marking" (Kulikov 2009) in diachronic perspective is the emergence of the so-called excessive case in Finnic (southeastern dialects of Finnish; Ingrian and Votic). As manifested in the dozens of examples presented by Särkkä (1969: 142ff.), the excessive as a productive case is most often used to express cessation 
of a given state or role (such as an occupational or social role) of a human referent. As such, both the morphological makeup and the semantic functions of the excessive marker - nt (a) seem to be a combination of the Finnic essive in -n(a) (e.g., keträjän (Standard Finnish kehrääjänä) 'as a spinner' in example (12)) and the partitive (historically ablative) in $-t(a)$ :

Finnish (Tyrö, Ingria)

\begin{tabular}{|c|c|c|c|}
\hline $\begin{array}{ll}\text { olin } & N \\
\text { be.PST.3SG } & 1\end{array}$ & $\begin{array}{l}\text { Narvas } \\
\text { Narva.INE }\end{array}$ & $\begin{array}{l}\text { keträjän, } \\
\text { spinner.ESs }\end{array}$ & $\begin{array}{l}\text { pääsiäisen tulin } \\
\text { Easter.ESs come.PST.3SG }\end{array}$ \\
\hline $\begin{array}{l}\text { keträjänt } \\
\text { spinner.EXCE }\end{array}$ & ESS & & \\
\hline
\end{tabular}

Quite obviously, the main reason for the emergence of this typologically rare case marker is analogy created by the otherwise almost symmetrical system of new and old local cases in the languages in question (see Kiparsky 2012: 31-32). However, none of the components represent "unmarked" latives that form the foundation of Korhonen's $(1975,1979)$ argumentation.

For the record, it can be added that one more type of situation where one case suffix may follow another, more historical one, is when nouns like North Saami illu 'joy' and miella 'mind; desire' have had their locative forms reanalyzed as adjectives with the meanings 'joyful, happy' and 'pleased; glad', respecively. Although not recorded as independent lexical items in dictionaries, ilus and mielas are also adjectives that may occasionally be inflected further in case (and number, e.g. illosat [glad.PL] in contrast to iluin [joy.PL.LOC]):

North Saami

$\begin{array}{llllll}\text { Lean ilus ahte diet prográmma lea ollán } \\ \text { be.1SG joy.LOC COMP } & \text { that program } & \text { be.3SG } & \text { reach.PST.PTCP } \\ \text { nu olu olbmuide. } & \text { Beare dat dagai } & \text { mu } \\ \text { so many people.PL.ILL } & \text { only it make.PST.3SG } & \text { 1SG.GENACC }\end{array}$

ilusin.

glad.Ess $(<$ joy.LOC + Ess $)$

'I'm glad that the program has reached so many people. That was enough to make me happy' (https://www.instagram.com/p/oggHuCjzGm/ 6.5.2016)

Unlike the case-stacking phenomena seen in East Mari (6), Udmurt (7) and Erzya (8), the North Saami locative is not a productive source of 
new lexical items. Incidentally, North Saami ilus is formally identical and etymologically related to Estonian ilus 'beautiful', which was mentioned by Weske (1884: 88-89) in his early attempt to explain the $s$-cases (Section 3.1). Further, the rise of the North Saami adjectives ilus 'joyful, happy' and mielas 'pleased; glad' is distantly related - but diachronically opposed - to Tauli's (1956) and Alhoniemi's $(1988,2001)$ thoughts about a derivational origin of the lative in ${ }^{\star}-s$ (Section 3.4$)$.

\subsection{Additional remarks}

Much of the neglect of semantic issues in the history of research of the origins of the $s$-cases can be understood in light of the Neogrammarian paradigm in which the functional aspects had to give way to regular sound changes such as ${ }^{*}-s V n>-h V n>-V n$ in suffixal positions in Finnish. However, as pointed out by critics (Wiklund 1927) and also admitted by proponents of the ${ }^{*}$ s-lative (Erkki Itkonen 1966a), the lative theory is not without phonological problems either. In addition to the shortcomings already discussed in earlier literature, the research tradition also contains some minor arguments and examples that have never been critically evaluated. The Erzya adverb onsne in a dream' is one such example.

The forms of the Mordvin inessives (Erzya -so, -se; Moksha -sa) do not contain any perceivable traces of the nasal ${ }^{*} n$ postulated on the basis of the Saami (South Saami -sne, etc.) and Finnic (e.g., -ssa, dialectal Finnish -hna and dialectal Estonian $-h n$ ) forms. To prove the identity of the Mordvin inessive with those of Saami and Finnic, a repeatedly cited example is the Erzya adverb onsne 'in a dream' ( $\leftarrow$ on 'dream') (e.g., Budenz 1879: 35-36; Donner 1879: 78; Beke 1911: 191). Even long after Ravila (1935: 46-47) argued that -sne here is best regarded as a sporadic contamination of the suffixes -se and (apparently locative) -ne, onsne has been used as a proof of a more or less regular sound correspondence between the inessives (e.g., Erkki Itkonen 1977: 124; Bartens 1999: 79) in the various branches. However, onsne is an extremely rare word that is even absent in Paasonen's voluminous dictionary, and in any case we are dealing with a hapax legomenon that can hardly be considered an "example" of anything relevant that could add to our understanding of the $s$-cases. Moreover, while the consonants of onsne have been presented as a simple proof of the origins of the Mordvin inessive, it is symptomatic that the unexpected vowel disharmony (onsne instead of ${ }^{* *}$ onsno; cf. the actual inessive form onso) has not raised any doubts in this context. 
On the other hand, the Erzya pronominal adverbs kozo 'whither' and tozo 'thither' and especially their dialectal variants kozoy and tozoy have been mentioned as possible support for the view that the most original form of the Saami and Finnic illative markers ${ }^{*}$-sin can ultimately be reconstructed as ${ }^{\star}-s V \eta$ with descendants in Mordvin, too (Bartens 1999: 115; Ylikoski 2011: 264). However, it has been pointed out by Inaba (2015: 223) that in the dialects that seem to have preserved the most original forms, an identical final consonant $-\eta$ can also be heard in words such as lo $\eta$ 'snow' (instead of lov < Proto-Uralic *lumi). Moreover, in old literary Erzya one can encounter nouns like lom 'snow' and directional expressions such as the lative postposition alom (pro alov, aloy) '(to) under, below', and for this reason Inaba calls for further research before it will be safe to reconstruct a lative in ${ }^{*}-\eta$ in Mordvin. Otherwise, it still seems safe to follow Setälä (1915: 23), Janhunen (1998: 469) and Bartens (1999: 76) in considering ${ }^{*}-y$ the most plausible reconstruction of any of the claimed Proto-Uralic lative cases (cf. Ylikoski 2011: 256-257). If Erzya kozoy and tozon are regarded as the most conservative variants of the adverbs in question, the element -zon can also be interpreted as the most original reflex of the Pre-Mordvin illative marker ${ }^{*}$-siy. This in turn would be identical to the more original predecessors of the illative marker ${ }^{\star}$-sin in both the Saami and Finnic proto-languages (cf. Table 3 in Section 2.2). ${ }^{16}$

In contrast to the most problematic claims of the received view on the origins of the $s$-cases, it can be remarked that the contributions to and descriptions of the lative theory largely lack certain kinds of examples that could well be expected from a Proto-Finno-Volgaic local case. As mentioned in Section 2.4, a major proof of the Proto-Uralic locative ${ }^{*}-n a$ and ablative ${ }^{\star}$-ta are the many postpositions and adverbs based on relational spatial nouns like as *ül(i)- 'location on/above', such as Aanaar Saami alne 'on, off', Finnish yllä 'above' and West Mari ßolnə 'on' (<* $\ddot{u} l(i)-n \ddot{a})$; the list can be amended with Komi vilin and Tundra Nenets nyinya id., for example. For an opposite meaning, the combination of the Proto-Uralic stem for *ila- 'location under/below' and the ablative ${ }^{*}$-ta appears to have survived in Saami, Finnic, Mordvin, Mansi, Khanty and Samoyed - from South Saami vuelhtie 'from under' up to Nganasan $\eta i l$ 'ədə id. (SSA s.v. ala; Aikio 2006: 28). Directional cases are notoriously trickier, but it is possible to think that dialectal Finnish ala, Erzya alov (aloy), Komi ule and Tundra Nenets $y i l^{\circ} h$ '(to) under, below' may all go back to the Proto-Uralic lative form ${ }^{\star}$ ila- $\eta$ (cf. Ylikoski 2011: 257). 
The allegedly Proto-Finno-Volgaic lative in ${ }^{\star}-s$ seems to have very few remnants similar to those just mentioned. The only examples come from Saami and Finnic, and as seen in Section 3.2, the very impetus of Jännes (1890) and Setälä's (1890) lative hypotheses were Finnish adverbs such as alas 'downward', ulos 'to the outside' and ylös 'upward', for which it was possible to find cognates such as North Saami vuolás 'downward', olggos 'to the outside' and alás 'upward (in terrain)', respectively. However, in addition to the absence of such words in Mordvin and Mari, it has been well known ever since Wiklund's (1927) criticism of Setälä (1890) that even the Saami and Finnic words suffer from mutual irregularity. For example, the expected North Saami counterpart of Finnish alas would be ${ }^{* *} v$ uolis, or on the basis of North Saami vuolás one would expect ${ }^{* *}$ alaksi in Finnish (see also Erkki Itkonen 1966a: 273).

Interestingly, all proposed direct successors of the ${ }^{*} s$-lative in Saami and Finnic seem to function as adverbs only, not as postpositions. ${ }^{17} \mathrm{How}-$ ever, it is even more notable that although most of the about ten adverbs belonging to the proposed group of remnants of the ${ }^{*} s$-lative are based on stems that do have cognates in other branches, no ${ }^{*} s$-lative cognates of adverbs like Finnish alas 'downward', ulos 'to the outside', ylös 'upward', edes 'at least, even', kauas 'far (away)', lähes 'nearly, almost' or taas 'again' have been presented from Mordvin or Mari (cf. SSA s.v. esi, kauka-, lähi-, taas, taka-). Apparently, the only candidate for a set of Finno-Volgaic parallel forms - but never explicitly discussed in relation to $s$-cases - could be Finnic (Finnish) myös 'also, too', (North) Saami mayás 'backwards, since' and Mari (East Mari) möngeš, (West Mari) mangeš 'back(wards)', but the relationship of these words is uncertain for both phonological and semantic reasons (see also Saukkonen 1959; Hakulinen 1979: 110). On phonological grounds, at least the Saami word seems to go back to the so-called translative in ${ }^{*}-k s i$ (Sammallahti 1998: 253).

Incidentally, it can be added that Salminen (2014: 299-300) has recently pointed out that Finnish edes 'at least, even' (no known cognates in Saami or elsewhere) could, paradoxically enough, in principle be related to two different words in Tundra Nenets:

1) Tundra Nenets yir $q^{\circ}$ 'opposite to; towards' < Proto-Samoyed *erit < Proto-Uralic ${ }^{\star} e \delta i s>$ Finnish edes 'at least; (not) even'

2) Tundra Nenets nyer ${ }^{\circ}$ 'earlier, already' < Proto-Samoyed ${ }^{\star}\left(\dot{n}^{\prime}\right) \ddot{a} r a t<$

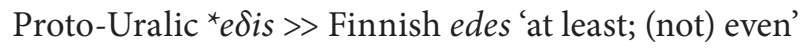


While I am not taking a stand on the validity of these etymologies apart from the fact that it is logical to assume that at least one of the two must be false, it must be concluded that the proposed Samoyed cognates do not support but only serve to reduce the trustworthiness of the received view about the emergence of the ${ }^{*} s$-lative in Proto-Finno-Volgaic.

The use of haphazard examples like Erzya onsne 'in a sleep' and the absence of more predictable, functionally and etymologically plausible lexicalized remnants of ${ }^{*} s$-lative forms outside Saami and Finnic are not the most crucial obstacles to the acceptance of the lative theory in general, but do not add to its credibility either. The following section attempts to provide a more careful yet optimistic approach to the possibilities of reconstruction of the origins of the western Uralic $s$-cases.

\section{Discussion and further remarks: What can be said about the origins of the s-cases?}

Besondere aufklärung über das sprachliche leben schenken die überwuchernden formen des Samojedischen, die wie beschwerliche wege in einem wildniss den wanderer müde machen. Und doch kämpft sich auch da der menschlich geist allmälich durch in seinem streben zum höheren bewusstsein.

(Donner 1881: 251)

As stated briefly in the previous section, it is commonly known that case affixes usually arise from adpositions (Kahr 1976; Heine 2009; Kulikov 2009; Creissels 2009). However, as discussed in more detail by Ylikoski (2011), Uralists have traditionally had a peculiar tendency to resort to the so-called latives and other bound morphemes such as derivational affixes as the source of new local cases. Although the rather transparent postpositional origins of Hungarian local cases have been obvious since the 19th century (e.g., Riedl 1858: 38-40; Balassa 1884: 158; Simonyi 1907: 258, 392 et passim), scholars of northern Uralic languages have been eager to develop alternative explanatory models such as the ${ }^{*}$ s-lative with an extraordinary ability to be combined with other local cases without any obvious restrictions. ${ }^{18}$

The naturalness of postpositional origins of case suffixes has not escaped the notion of lative theorists either. However, in referring to the emergence of Hungarian local cases and to the development of the $s$-cases as well as the Finnic and Permic $l$-cases, Korhonen (1981b) makes the following statement: 
It is possible that a similar development also took place during the earliest phases of the Finno-Ugrian languages, but because these suffixes are most inclined to undergo luss [sic] and analytical change, the traces of possibly very old fusions have disappeared. Therefore, for example, such claims that the Finno-Permian cases containing the $l$ element (as in the Finnish external local cases) and the Finno-Volgaic cases containing the $s$ element (as in the Finnish inner local cases) are developments from the fusion process of the postpositions luo- and sisä- stems onto the head $\left({ }^{\star} k a l a n\right.$ lona $>{ }^{*}$ kalanlena $>{ }^{*}$ kalalena $>{ }^{*}$ kalalna $>$ kalalla 'fish' with the adessive marker; ${ }^{*}$ kalan sisänä $>{ }^{*}$ kalansisnä $>{ }^{*}$ kalasna $>$ kalassa 'fish' with the inessive marker) cannot be proved, but neither would it be possible to refute the claim. In fact, it would be very practicable and also be a fine example of the common development postulated for Finno-Ugrian on the basis of the early history of the cases, as I outlined previously. However, these cases are regarded as developments of a completely different process, the other of the main processes which have produced the new cases in the Finno-Ugrian language family. (Korhonen 1981b [1996: 202]) ${ }^{19}$

Korhonen's words “cannot be proved, but neither would it be possible to refute the claim" certainly apply to any potentially serious theories about the distant past of the Uralic languages. In his paper, he goes on to argue for the lative theory on the origins of the $s$-cases. However, as discussed above, the lative theory has obvious shortcomings which justifies further search for alternative explanations, regardless of the fact that they cannot be proved.

Some potential theories are more concrete than others, and thus easier to prove or refute than the more abstract ones. Before returning to relatively concrete reconstructions like postpositions and latives, as an example of abstract explanations one can recall Tauli's (1956) thoughts mentioned already in Section 3.1:

It is obvious that at the time when the locative suffix - na and the ablative suffix -ta were added to the suffix $-s$ the latter could not have lative function, but it had either the function of a general local case or it was conceived as belonging to the stem. Since there is no foundation for the first assumption, then it is more natural to assume that at the time when the internal local cases sprang into existence, the $-s$ suffix occurred as an element of the stem, i.e. as a derivational suffix. (Tauli 1956: 207-208)

Tauli does not present a concrete candidate for the derivational suffix from which the element ${ }^{*}$-s- could derive. Although such candidates have been mentioned by others (cf. Section 3.3), the most "meaningless" and thus quite plausible explanation could be that ${ }^{*}$-s- has never had any meaning of its own, in other words a semantic function that would have changed or modified the meaning of the primary local cases reconstructed for Proto- 
Uralic. As such, meaningless linguistic elements are not morphemes, but only phonological segments, regardless of whether such segments are labeled as "coaffixes" as in Uralistics or not.

One of the most natural explanations for the origins of a per se meaningless coaffix ${ }^{*}$-s- could be that instead of going back to a derivational suffix whose original meaning has not been - and perhaps cannot be - identified, the element could originate in a likewise meaningless segment on the other side of the border of (underived) lexical stems and case suffixes. The emergence of the new case suffixes could thus be analogous to the development of the Estonian plural partitive in -sid, for example. According to Alvre (1966), it can be hypothesized that partitive plurals such as sõnasid (of sõna 'word'; cf. Proto-Finnic *sana-j-ta [word-PL-PTv]) go back to mixed paradigms such as Proto-Finnic *hepoi [horse.NOM] : ${ }^{\star}$ hepoilla [horse.ADE] $={ }^{*}$ hepoiset [horse.PL.NOM] : ${ }^{\star}$ hepoisilla [horse.PL.ADE] in which the element ${ }^{*}$-se- (plural ${ }^{*}$-si-), originally a diminutive marker, was analyzed as a plural marker to which the partitive suffix $-d$ could be added. The element -sid then became a productive grammatical element that could be attached to new nouns without direct relation to the original ${ }^{*}$-se-forms, yielding more agglutinative partitive plural forms such as sonna-sid alongside the more original sõnu. However, even Alvre's reconstruction of the relatively recent development of the Estonian suffix is quite vague in nature, and in the absence of obvious candidates for similar models in much more distant proto-languages, it seems realistic to refrain from claiming that the western Uralic $s$-cases have emerged by way of similar metanalysis, even though this possibility cannot be refuted either.

\section{I. A Samoyed perspective on the s-cases}

What, then, can be said about the origins of the s-cases? Instead of referring to a mere - albeit fully reasonable - possibility of a metanalysis of noun stems in a possible Finno-Volgaic proto-language or other protolanguages in the distant past, or to the directional case, "*s-lative" that was amended by all other local cases as soon as it had appeared ex nihilo (cf. Section 4.1), it is more stimulating and more in accord with the methods and aims of historical linguistics to seek the origins of the $s$-cases by means of comparison. According to the received view, the $s$-cases are a Finno-Volgaic innovation, and, at the same time, the Finno-Volgaic affinity is described as being evidenced by innovations such as - but not much 
more than - the s-cases, and from this perspective it can be concluded that almost everything that has been said about the emergence of these cases is based on internal reconstruction only. In other words, the dominant theory about the origins of the $s$-cases in Saami, Finnic, Mordvin and Mari is almost entirely based on the evidence that only these branches can provide. Although earlier scholars (e.g., Budenz 1879: 35-36; Donner 1879; Szinnyei 1910: 79; cf. Sections 3.1 and 3.2) compared these cases with various cases and case-like adverbial elements in Permic, Khanty, Mansi and Hungarian, their followers have mostly rejected or plainly ignored such comparisons, which must be regarded as quite vague and random indeed.

Incidentally, however, it appears that the Samoyed languages and their research history can reveal insights that seem to have been overlooked by Finno-Ugrists working with the westernmost languages of the family. It can be noted, however, that in discussing the development of the Mordvin and Finnic case markers, Bartens (1999: 78) and Lehtinen (2007: 79) have referred to the fact that the locative and ablative case markers of the Samoyed languages have coaffixes whose reconstructions $\left(^{*}-k\right.$ - and $\left.{ }^{*}-n t z-\right)$ are formally identical to the reconstructed forms of the Proto-Samoyed lative case markers, and this is seen as a supporting parallel to the traditional lative theory in which a directional case suddenly has come to serve as a mere platform to which other local case suffixes have been attached.

To ease the comparison between the western Uralic s-cases (Tables 2 and 3 ) and the " $k$-cases" and " $n t \partial$-cases" in Samoyed, Table 8 depicts the position of the elements ${ }^{*}-k \partial$ - and ${ }^{*}-n t z-$ as reconstructed for ProtoSamoyed. While relational spatial nouns have retained the supposedly original, coaffixless case marking, according to Janhunen (1998: 469), the locative and ablative case markers of ordinary nouns are "based on the coaffixal use of the elements ${ }^{*}$-kø- and ${ }^{*}$-ntø(-), which function basically as dative/lative endings with a varying distribution in the modern languages". ${ }^{20}$ The main difference between the individual languages is that Nganasan is the only language whose locative case marker -tənu seems to go back to ${ }^{*}$-ntəna, while other locatives such as Tundra Nenets -xəna share the coaffix ${ }^{*}-k \partial-$.

While Janhunen (1998: 469) somewhat ambiguously states that the elements ${ }^{*}-k \partial$ - and ${ }^{*}$-nto- are both coaffixes (in the locative and ablative markers) and also "function as dative/lative endings", unlike scholars such as Mikola (1988: 237-239), Bartens (1999: 78) and Lehtinen (2007: 79) he does not directly claim that any of the locative or ablative markers his- 
Jussi Ylikoski

\begin{tabular}{|c|c|c|c|c|}
\hline & Spatial nouns & Ordinary nouns & & \\
\hline Nominative & & & $*-\varnothing$ & \\
\hline Accusative & & & ${ }^{*}-m$ & \\
\hline Genitive & & & $*-n$ & \\
\hline Dative/lative & $*-y$ & $*-k a-$ & & ${ }^{*}-n t \partial(-\eta)$ \\
\hline Locative & $*-n a$ & $*-k \partial-n a$ & & ${ }^{*}-n t \partial-n a$ \\
\hline Ablative & ${ }^{*}-t(\partial)$ & ${ }^{*}-k \partial-t(\partial)$ & & \\
\hline Prosecutive & ${ }^{*}-m-n a$ & & ${ }^{*}-m \partial-n a$ & \\
\hline
\end{tabular}

Table 8: Case markers in Proto-Samoyed according to Janhunen (1998: 469)

torically originate in the directional case suffix to which the original locative and ablative suffixes have been attached. Indeed, homonymy of elements such as the Samoyed latives ${ }^{*}-k \partial$ and ${ }^{*}-n t \partial(-\eta)$ and the coaffixes in other cases does not necessarily imply that the elements actually share a common origin. The same applies to the homonymy of the Mordvin lative marker $-s$ and the coaffix perceived in the inessive $(-s o)$ and especially the elative $\left(-s t o<^{*}-s_{-}+{ }^{*}-t a\right)$. On the contrary, it must be noted that at least in the Uralic languages, it is the directional cases that clearly show a general tendency to develop and live faster than other spatial expressions. Even in the most recently emerged local case series, in which the "coaffixes" are undeniably based on postpositional stems that are followed by the more original case suffixes, directional cases such as the Hungarian illative $-b a$ and allative - $r a$ or Southern Permyak illative $-e$ and superlative $-(v) v e(<$ vil-e [on-ILL]) are materially lighter (i.e. phonologically shorter) compared to static, separative and other corresponding cases (see Ylikoski 2011: 264,275 and references therein). One reason for this may lie in the relative frequency of directional cases in comparison to other local cases (cf. Korhonen 1975: 113-114).

In Hungarian, all three internal cases share the element - $b$-, and two of the three surface cases share - $r$-. In Southern Permyak, the surface cases all share the element $-v$-. However, even though the term coaffix is not limited to diachronic studies, the elements $-b-,-r$ - and $-v$ - are seldom characterized as such, because from a diachronic perspective, they are not merely opaque coaffixes but go back to ${ }^{\star} b$ - ${ }^{\star} r$ - and ${ }^{\star} v$-initial postpositional relational nouns. Without going into the original makeup of the individual suffixes seen in Table 9 (for which see Ylikoski 2011 and references there- 
The origins of the western Uralic s-cases revisited

\begin{tabular}{|c|c|c|c|c|}
\hline & & Direction & Location & Source \\
\hline Hungarian & Internal cases & $\begin{array}{l}\text { kéz-be } \\
\text { '(in)to the } \\
\text { hand' }\end{array}$ & $\begin{array}{l}\text { kéz-ben } \\
\text { 'in(side) } \\
\text { the hand' }\end{array}$ & $\begin{array}{l}\text { kéz-böl } \\
\text { 'from (inside) } \\
\text { the hand' }\end{array}$ \\
\hline \multirow{3}{*}{$\begin{array}{l}\text { Southern } \\
\text { Permyak }\end{array}$} & Surface cases & $\begin{array}{l}\text { kéz-re } \\
\text { 'onto the } \\
\text { hand' }\end{array}$ & $\begin{array}{l}\text { kéz-en } \\
\text { 'on the hand' }\end{array}$ & $\begin{array}{l}\text { kéz-röl } \\
\text { 'off the hand' }\end{array}$ \\
\hline & Internal cases & $\begin{array}{l}k i-e \\
\text { '(in)to the } \\
\text { hand' }\end{array}$ & $\begin{array}{l}k i \text {-in } \\
\text { 'in(side) } \\
\text { the hand' }\end{array}$ & $\begin{array}{l}\text { ki-iś } \\
\text { 'from (inside) } \\
\text { the hand' }\end{array}$ \\
\hline & Surface cases & $\begin{array}{l}\text { ki-ve } \\
\text { 'onto the } \\
\text { hand' }\end{array}$ & $\begin{array}{l}\text { ki-vin } \\
\text { 'on the hand' }\end{array}$ & $\begin{array}{l}k i-v i s \\
\text { 'off the hand' }\end{array}$ \\
\hline
\end{tabular}

Table 9: Hungarian and Southern Permyak internal and surface local cases exemplified with the nouns for 'hand, arm'; only directional, static and separative cases are presented ${ }^{21}$

in), it suffices to state that from a synchronic - and perhaps also from a diachronic - point of view, the case series seen here are quite similar to the western Uralic $s$-cases. Indeed, in light of the concept of "lative" and its versatility in the emergence of new cases, it is not impossible to think that without the historical evidence of the postpositional origins of the $b$-, $r$ - and $v$-cases, they, too, would have been explained away by referring to hypothetical lative suffixes ${ }^{*}-b(V),{ }^{*}-r(V)$ and ${ }^{*}-v(V)$ followed by more original case markers. However, from the opposite point of view it would be equally plausible - and typologically much less doubtful - to regard the western Uralic s-case markers as remnants of ancient postpositions. In other words, instead of viewing the Mordvin lative marker $-s$ and possibly also the Mari lative in -(e)š as the best preserved instances of a Proto-Finno-Volgaic lative, they could be seen on a par with Hungarian - $b a$ and $-r a$ as well as Southern Permyak -ve, all of which are but remnants of former postpositional stems, supposedly originally followed by the lative suffixes ${ }^{*}-k$ or ${ }^{*}-j$ (cf. Ylikoski 2011 and references therein).

To return to the local cases in Samoyed, the history and origins of the coaffix ${ }^{*}-k$ - are not of utmost importance here, but it has no obvious cognates outside Samoyed. As described by N.-Sebestyén (1958: 306ff.), the coaffix ${ }^{*}-k$ - has also been regarded as a lative ever since Donner (1881: 239) and Budenz (1891: 89-98); see also Mikola (2004: 101). Resemblance to a compa- 
rable element in Yukaghir can be due to chance or language contact (Aikio 2014: 24-26). I will briefly return to the coaffix ${ }^{*}-k_{\partial}$ - in Section 5.2 below.

What is much more interesting from the perspective of the western Uralic s-cases, however, is that the element ${ }^{*}-n t \partial(-)$ has, in fact, at times been likened to the coaffix ${ }^{*}-s$-. On the other hand, unlike for the $s$-cases, there are also relatively recent proposals on the possibilities of explaining the Samoyed ${ }^{*}$-ntz-cases as originating in postpositional phrases. The following brief account of the marginal role of the western Uralic s-cases in Samoyedology was not presented in previous sections, as the studies in question have not addressed the problem of the origin of the western $s$-cases per se. The other way round, it seems that the studies and textbooks focusing on the westernmost languages have not paid any attention to what Samoyedologists like Györke (1943), N.-Sebestyén (1958), Mikola (1969, 1979, 2004) and Künnap $(1971,1981)$ have said about the history of an element that could in principle be regarded as a (Pre-Proto-)Samoyed coaffix ${ }^{*}-s-$.

In discussing the morpheme order in Uralic nouns, Györke (1943: 3839) made a conjecture that as the Finno-Ugric ${ }^{*} s$ is regularly represented by ${ }^{*} t$ in Samoyed and the coaffix ${ }^{*}$-nto- also has a nasalless variant ${ }^{*}$-to(Györke's <-nta> and <-ta>), in Nganasan followed by - nu (< Proto-Uralic locative $\left.{ }^{\star}-n a\right)$, it is possible to interpret the Nganasan locative $-(n) \operatorname{tanu}(<$ Proto-Samoyed ${ }^{*}$-ntə-na of Table 8 ) as a direct cognate of the western Uralic inessive in ${ }^{*}$-sna. Györke does not question the lative theory in any way, but merely expands it to cover the Samoyed ${ }^{\star} n t$-cases by referring to a Proto-Uralic lative in ${ }^{*}$-s $s$ - in other words, to a hypothetical common ancestor of both the coaffix ${ }^{*}$-s- in the west and ${ }^{*}$ - $(n)$ to- in Samoyed.

Györke's proposal was later dismissed by N.-Sebestyén (1958: 307, 336337), who briefly concluded that the theory suffers from phonological difficulties and therefore the Nganasan coaffix can be better explained as a spatial marker of a different origin. N.-Sebestyén (1958: 315) and Mikola (1969: 17-19) following her explained the coaffix *-ntə- (N.-Sebestyén's <-ndə>, $<-n d^{2}>$ ) as consisting of a lative in ${ }^{\star}-n$ followed by possessive suffixes in a determining function. However, Künnap (1971: 111) as one of the few critics of extravagant lative theories (see also Künnap 2002: 21) has doubted both explanations. In discussing the origins of the Samoyed lative, he suggests that the suffix might go back to the genitive in $-n$ followed by a directional postposition or rather, ambiguously enough, to "a stem-like, functionally less determinate pronominal-adverbial-postpositional particle *to" ("eine in Gestalt des reinen Stammes auftretende und funktionell unbestimmte- 
re pronominal adverbial-postpositionale Partikel"; p. 114). In addition to a general skepticism towards lative theories, Künnap repudiated (p. 115) Györke's suggestion about a Uralic *s ${ }^{*}$-lative simply by stating that contemporary scholars quite unanimously regarded the $s$-cases as a product of the Proto-Finno-Volgaic period.

Later on, Mikola (1979: 194) both denounced his own previous thoughts (Mikola 1969: 17-19) and rejected Künnap's hypothesis, suggesting - quite like Györke (1943) - that the second component of the element - ntV-, i.e. $-t V$-, is originally a lative marker that no longer exists as an independent lative suffix since becoming homonymous with the ablative marker (see Table 8) due to the sound change ${ }^{*} s>t$. However, this only indirectly relates the Samoyed coaffix to the western coaffix ${ }^{*}-s-$, as Mikola makes no explicit references to the western $s$-cases. Künnap (1981), in turn, has doubts about Mikola's proposal and criticizes him for both ignoring many details of noun inflection in individual Samoyed languages as well as for presenting his lative-based hypothesis as typologically more plausible than Künnap's postpositional hypothesis. Künnap does not comment on Mikola's proposal about a Pre-Proto-Samoyed lative in ${ }^{\star}-s$, though. ${ }^{22}$ For the present, the debate about the possible postpositional origins of the Samoyed cases seems to have come to a standstill after the second revision of Mikola's hypothesis (Mikola 2004). Again, yet still without reference to Györke (1943), he compares the Samoyed coaffix with the s-cases in the west and summarizes his view as follows:

Auf Grund all dessen halte ich für wahrscheinlicher, dass PS *-ntô aus zwei Lativsuffixen besteht, wie z. B. das tscheremissische Lativsuffix $-s ̌ k e ~\left(<^{*}-s k V\right)$ oder die vielgestaltige finnische Illativendung $\left(<^{*}\right.$-seń). Indem ich das Problem von $n$ vorläufig offen lasse, würde ich das Suffix ${ }^{\star} t a \hat{~ m i t ~ d e n ~ f o l g e n d e n ~ f i n n i s c h-u g r i s c h e n ~}$ Suffixen in Verbindung bringen: finn. ulos 'hinauf', ylös 'nach oben', Koaffix -s, lapp. qukkas [= Lule and North Saami guhkás] 'fern, weit', vuolas [vuolás] 'ab, nach unten', Illativsuffix $-s$ vor den Px, mord. Illativ $-s$, tscher. Lativsuffix -eš, Illativsuffix -ške. Wie bekannt, wurde PU ${ }^{*} s$ im Samojedischen zu $t$. (...) Die Fortsetzer der PS SgLatEndung ${ }^{*}-n t \hat{\jmath}$ begegnen in allen samojedischen Sprachen. (...) Die Lokativendung *-kânå *-kânä ist in allen samojedischen Sprachen erhalten, außer im Nganasanischen. Hier ist die Lokativendung (C) -ntan $V$, $-\tan V$ aus der Lativendung * $n t a ̂$ und der Lokativendung ${ }^{\star}-n V$ zusammengesetzt. (Mikola 2004: 100-101)

Without delving into the details of the variegated field of Samoyedology, it is evident that the question about the origins of the ${ }^{\star} n t$-cases is far from settled, and there is no consensus comparable to the received view 
on the origins of the western $s$-cases. The hypotheses summarized above are based on rather vague conjectures and suffer from the lack of typological parallels from other languages. However, instead of a synthesis of the competing hypotheses, it seems possible to construct a typologically more plausible bricolage consisting of the most fitting components of Györke, Künnap and Mikola's hypotheses. Frankly, the following compilation of their key points is not meant to be the most elegant explanation of the emergence of the Samoyed ${ }^{*} n t$ - -cases per se, but an attempt to present a typologically reasonable hypothesis that could indeed explain the emergence of the Saami, Finnic, Mordvin and Mari as well as Samoyed cases from a common ancestor.

The starting point for relating the western $s$-cases to the Samoyed ${ }^{\star} n t z$ cases must be Györke (1943) and Mikola's $(1979,2004)$ references to the fact that the Finno-Ugric ${ }^{*} s$ is represented as ${ }^{*} t$ in Samoyed, and on this basis also the coaffixes ${ }^{*}-s$ - and ${ }^{*}$-ntz- can be compared with each other. However, instead of accepting characteristically Uralistic theories about flourishing case stacking that lacks virtually all semantic constraints and parallels in other languages, it is typologically more trustworthy to adopt Künnap's (1971) hypothesis about the postpositional origins of the Samoyed coaffix. Although in Künnap's reconstruction the genitive in ${ }^{*}-n$ is followed by a pronominal-adverbial-postpositional particle ${ }^{\star}$ to and not an element with initial ${ }^{*} s$ - and he does not relate such elements to the western $s$-cases in any way - a Pre-Proto-Samoyed ancestor of Proto-Samoyed ${ }^{\star}$ tr could be a Proto-Uralic morpheme beginning in ${ }^{\star} \mathrm{s} V$-.

Thus, when all these threads are drawn together, it is possible to conclude that in principle, a large part of the most important local cases in Saami, Finnic, Mordvin, Mari and Samoyed (especially Nganasan) can originate in Proto-Uralic postpositional phrases governed by a series of postpositions beginning in ${ }^{*} \mathrm{~s} V$-. Most presumably, such postpositions have consisted of a relational noun stem ${ }^{\star} s V(. .$.$) - followed by the primary locative suffix { }^{*}$-na, ablative ${ }^{*}-t a$ and a directional "lative" case whose identity is less clear, ${ }^{\star}-\eta$ being the most plausible candidate (Ylikoski 2011: 256). On the basis of Saami, Finnic, Mordvin and Samoyed, it is possible to think that such postpositions have taken their complements in the genitive case already in Proto-Uralic as well. On the other hand, present-day Mordvin and Mari demonstrate that both nominative and genitive complements may be used within a single language (Alhoniemi 1993: 50; Bartens 1999: 89, 91), and this may certainly have been possible in Proto-Uralic. ${ }^{23}$ The pattern that emerges here can be 
condensed into Figure 5, which depicts a diachronic interpretation of the synchronic situation summarized in Table 10.

As the Samoyed lative and locative cases belong to the default local cases throughout the branch, their semantic functions do not need special attention in this context; see, for example, Wagner-Nagy (2002: 79-80) and

\begin{tabular}{llll}
\hline & Direction ('to') & Location ('at') & Source ('from') \\
\hline Saami & $\checkmark$ & $\checkmark$ & $\checkmark$ \\
Finnic & $\checkmark$ & $\checkmark$ & $\checkmark$ \\
Mordvin & $\checkmark$ & $\checkmark$ & $\checkmark$ \\
Mari & $\checkmark$ & $\checkmark$ & - \\
\hdashline $\begin{array}{l}\text { Samoyed } \\
\text { (Nganasan) }\end{array}$ & $\checkmark$ & $\checkmark$ & - \\
$\begin{array}{l}\text { Samoyed } \\
\text { (other) }\end{array}$ & $\checkmark$ & & - \\
\hline
\end{tabular}

Table 10: Presence of $s$-cases in Saami, Finnic, Mordvin and Mari and ${ }^{\star} n t z-$ cases in Samoyed (cf. Table 2)

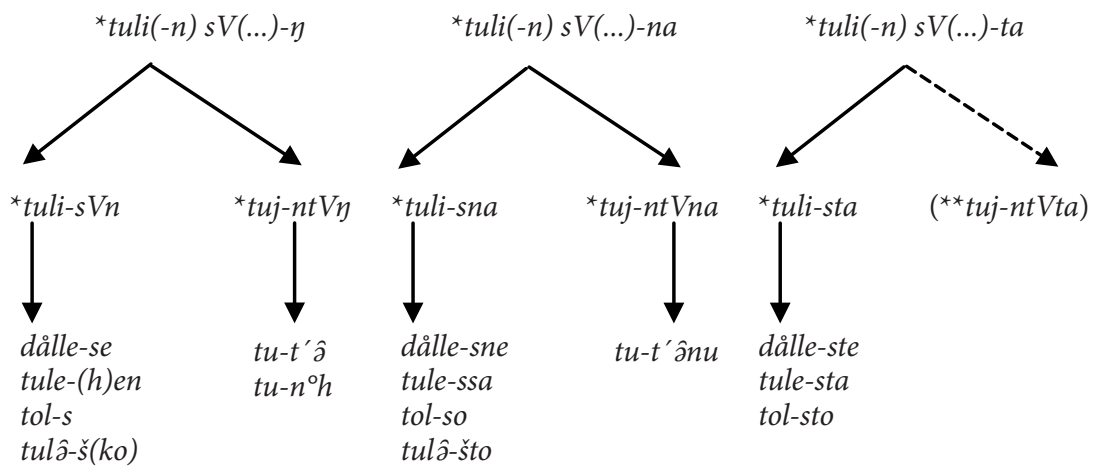

Figure 5: Hypothetical development of the western (Saami, Finnic, Mordvin and Mari) Uralic s-cases and the eastern (Samoyed) ${ }^{\star} n t$ to-cases from ProtoUralic postpositional phrases exemplified with the nouns for 'fire' in South Saami (Saami), Finnish (Finnic), Erzya (Mordvin) and East Mari (Mari) as well as Nganasan and Tundra Nenets (Samoyed) (cf. Table 2) 
Katzschmann (2008: 365-366) for Nganasan and Tereshchenko (1973: 252ff.) for Samoyed in general. The following example sentence serves to illustrate the use of both the locative and the lative case for the Nganasan descendants of Proto-Uralic *tuli 'fire' and *weti 'water', respectively:

Nganasan

$\begin{array}{llll}\text { tuutonu }^{24} & \text { igatum, } & \text { bito } & \text { siəokandum } \\ \text { fire.LOC } & \text { be.ITER.IPFv.PRS.1SG } & \text { water.LAT } & \text { drown.ITER.IPFV.PRS.1SG } \\ \text { 'I was in a fire, I drowned in water.' (Katzschmann 2008: 140) }\end{array}$

Translational equivalents of the Nganasan locative forms tuu-tanu or tu$t^{\prime}$ 'วu 'in a fire' in four western Uralic languages can be seen in Figure 5. Similarly, the lative bi-to '(in)to water' could be reconstructed as ProtoUralic * weti(-n) $s V(. .)-.\eta$ and thus considered a full cognate of the illatives

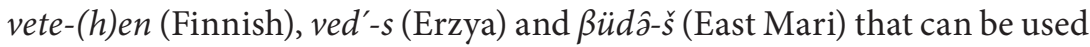
in nearly identical functions.

The hypothesis depicted in Figure 5 is by no means without problems, but it is probably not as problematic as the lative theory depicted in Figure 4. As a matter of fact, the postpositional hypothesis presented here is actually rather close to the early idea of explaining the western coaffix ${ }^{*}-s$ - as being cognate to the Finnic postpositional relational noun sisä- 'inside' (e.g., Lönnrot 1841: 36-37; Ahlqvist 1863: 26-27; Hunfalvy 1864: 301; see Section 3.1), later condemned as unscientific (Setälä 1890: 411) or at best unprovable (Korhonen 1979: 9). Instead of accepting the sisä-hypothesis, however, it would be far more logical to look around for less noticeable candidates for the original postpositions. Finnic sis $\ddot{a}$ - has obvious cognates in Saami only (SSA s.v.), and it would, in fact, be quite peculiar to find the postpositional cognates of the coaffix ${ }^{*}$-s- precisely in the two branches in which the coaffixal nature of $s$ is at its clearest.

For the record, it can be noted that in some Saami languages, cognates of Finnic sisä- do have - along with some other postpositions - morphological and syntactic features that occasionally make them look like potential case markers of the future languages (Bartens 1978: 191-195). Aanaar Saami kaassâsiis (16), a contraction of the more original kaas(s)â siisâ [box. GEN into] (cf. 15), is a case in point - in spite of the fact that <kaassâsiis > is either an intentional or unintentional deviation from the standard orthography. In the same vein, a North Saami corpus (SIKOR) contains a number of amalgamated postpositional phrases such as áiddesisa pro áiddi sisa [fence.GENACC into] 'to the inside of the (reindeer) fence' and 
ealosiste pro ealu siste [herd.GENACC in] 'in the reindeer herd' exhibiting the so-called allegro shortening (see Sammallahti 1998: 41-42) that usually affects the stem vowel in compounds.

Aanaar Saami

(15) Eeči raahtij

$\begin{array}{lll}\text { feci raahtij } & \text { luovdijn } \\ \text { father } & \text { make.PST.3SG } & \text { board.PL.LOC }\end{array}$

piejâi pissoid já kiirjijd.

put.PST.3SG gun.PL.ACC and book.PL.ACC

'Father made boxes from boards, and put guns and books in them.' (SIKOR)

(16)

\begin{tabular}{|c|c|c|}
\hline $\begin{array}{l}\text { Pieijim } \\
\text { put.PST.1SG }\end{array}$ & $\begin{array}{l}\text { taid } \\
\text { it.PL.ACC }\end{array}$ & $\begin{array}{l}\text { kaassâsiis } \\
\text { into.the.box [= box.GEN into] }\end{array}$ \\
\hline $\begin{array}{l}\text { valdim } \\
\text { take.PST.1SG }\end{array}$ & $\begin{array}{l}\text { fáárrun. } \\
\text { in.compar }\end{array}$ & \\
\hline
\end{tabular}

However, instead of regarding forms like Aanaar Saami kaassâsiis 'into the box' (16) as reborn $s$-cases (cf. illative kaasâ- $n$ id. whose suffix $-n$ goes back to Proto-Saami ${ }^{*}$-sen; Sammallahti 2009), it ought to be more natural to find the original postpositions preserved in branches where they have not resulted in a coaffix or a series of new case suffixes. ${ }^{25}$ It must be admitted that many such cognates are not readily available in the remaining branches, i.e. Permic and Ugric (or Mansi, Khanty and Hungarian). In principle, however, a possible candidate could be North Khanty Lipi 'inside (n.), interior (n.); intestines' and East Khanty tiypi id., as such a relational noun with a Proto-Khanty initial ${ }^{{ }^{*} L}$ could be a reflex of a Proto-Uralic one with initial ${ }^{\star} s$ (> Proto-Samoyed $\left.{ }^{{ }^{*}} t\right)$. The morpheme in question is used as an ordinary noun (see, e.g., Karjalainen 1948 s.v. $t \bar{l} B 3$ ), but it also serves as a basis for spatial postpositions such as North Khanty Lipija [inside.LAT] '(in)to' and Lipijn [inside.Loc] 'in' (see, e.g., DEWOS 727-728; Schön 2014: 215-216; Solovar 2014 s.v. лыıи, лыпийa). See also (17) from East Khanty (cf. also Filchenko 2010: 207); in the original source, the prosodic unity of the postposition and its modifier - often a sign of tentative

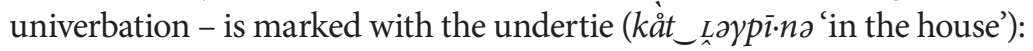

\footnotetext{
Yugan (East) Khanty

kàt Loypīno

house inside.LOC corpse there lie.PRS.3SG

'There was a corpse lying in the house.' (Vértes 2001: 68)
} 
However, the stem Lipi, tippi in itself originates in a more complex compound or derivative that cannot be considered a direct cognate of the coaffixes as such. According to UEW, the first part of the stem - best visible in compounds such as Vakh (East) Khanty loy-pelok 'inside, interior' (DEWOS 727-728) - can be tentatively equated with Finnic seka- 'mix, (sthg) mixed' (UEW 438-439: “Zwischenraum, Mitte"). ${ }^{26}$

As remarked by Luobbal Sámmol Sámmol Ánte (p.c.), Proto-Khanty ${ }^{*}$ Li - could go back to Proto-Uralic ${ }^{\star} s e k V$ - or ${ }^{*}$ sexi-. Therefore, it seems that the formally closest possible cognate of ${ }^{\star} L i \gamma$ - in other branches would be Proto-Saami ${ }^{*}$ seahke (> North Saami seahki 'confusion, disorder', etc.) which has been considered a Finnic loan (UEW 438; Sammallahti 1998: 130; SSA s.v. seka) but could in principle go back to Proto-Uralic ${ }^{*}$ sekä-. In fact, although most of the Finnic cognates of the Saami word have the stem seka- sega-, the vocalism of Võro segä-suggests that ${ }^{*}$ sekä- may also be the Proto-Finnic cognate of the Proto-Saami ${ }^{*}$ seahkē, which needs not necessarily be regarded as a Finnic loan after all. Saami ${ }^{\star}$ seahkē and Finnic *sekä-do not refer to 'disorder' only, but they also serve as relational noun stems to postpositions like Lule Saami siegen 'with; among; in the middle of'. The meaning of such grammatical words comes rather close to cases and postpositions with predominantly local functions:

Lule Saami

$\begin{array}{lllll}\begin{array}{l}\text { Gå bállov duoj } \\ \text { when ball.ACC that.PL.GEN }\end{array} & \begin{array}{l}\text { ietjá } \\ \text { other.GEN boytjaj }\end{array} & \begin{array}{l}\text { siegen } \\ \text { among }\end{array} \\ \text { tjievtjaj, de lij } & \text { David Beckhama } & \text { lágásj. } \\ \text { kick.PST.3SG dpt be.PST.3SG } & \begin{array}{l}\text { David Beckham.GEN } \\ \text { alike }\end{array} \\ \text { 'When he was playing football among those other } & \\ \text { boys, he was like David Beckham.' (SIKOR) } & \end{array}$

Of course, the postpositional hypothesis outlined here does not even presuppose a morpheme with a meaning as specific as 'inside' or 'middle', but the development of the Hungarian $b$-cases - evidently akin to words such as bel- 'internal', bél 'intestines' and belül 'inside' - clearly shows that such postpositional constructions can become the default local cases of a language. For one of many more distant parallels, cf. also the development of Proto-Bantu *-ini 'liver' into a default locative case marker in many Bantu languages such as Swahili (Samson \& Schadeberg 1994), and the Prasuni (Nuristani) locative prefix $t u$-going back to the Common Indo-Iranian preposition antár 'within, inside, between' (Kulikov 2009: 
444-445). If the $s$-cases were to stem from analogous postpositions, this would also explain the absence of a commonly accepted etymology for a Proto-Uralic spatial noun meaning 'inside, interior'. On the other hand, if the origins of the $s$-cases and ${ }^{\star} n t z$-cases can be traced up to Proto-Uralic, this certainly diminishes our possibilities of understanding their origin and the ultimate functional motivation for replacing the most original Uralic local cases.

Pulling all the threads together, perhaps the most plausible reconstruction of the stem ${ }^{*} s V(.$.$) - presented above (Figure 5) is Proto-Uralic { }^{*}$ se $C V$ - ( ${ }^{*}$ sekä-, ${ }^{\star}$ seki- or ${ }^{*} \operatorname{sex}(i)$-) 'inside, interior'. This would mean that the westernmost locative case forms in Uralic, the South Saami inessives such as dalle-sne 'in the fire', as well as the very easternmost ones such as Nganasan $t u-t^{\prime} \partial n u$ id., could be reconstructed as going back to the Proto-Uralic postpositional phrases like ${ }^{\star} t u l i(n)$ sekänä/sekinä/sex(i)nä 'in(side) the fire'. Accordingly, the corresponding directional and separative cases would originate from the

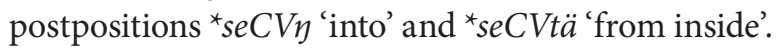

\subsection{Old problems and new horizons}

Despite the multiple suggestions just presented, it seems safe to refrain from making too strong claims about the cognates of either the $s$ - or ${ }^{\star} n t$ cases in other branches at the present stage of research. As the hypothetical postpositions seem to have agglutinated several millennia ago, it is understandable that their current successors may have departed very far from their original forms and functions. When considering reconstructing the original shape of the postpositional stem, it is essential to remember that the suffixation of independent postpositions is by definition an extraordinary process which cannot be based on any sound laws whatsoever. A regular development could only have led to the maintenance of the postpositions as independent words: While the Komi postpositional phrase $m u$ vil-in [earth on-INE] 'on the earth' can be regarded as a more or less expected reflex of Proto-Uralic *mixi-n ül(i)-nä, the Southern Permyak superessive form $m u$-vin id. (<*mu vilin) or Olonetsian $m u a-l$ [earth-ADE] id. are, from a purely phonological point of view, rather anomalous cognates of the Komi phrase. In the same vein, the Latin prepositional phrase super humum 'on the earth' is a more or less direct reflex of the Proto-Indo-European words ${ }^{\star}(s-) h_{1} u p e ́ r(i)$ and ${ }^{\star} d h e ́ g h o m$, whereas its Ossetic equivalent $z \propto x x-y l$ [earth-ADE] 'on the earth' is an adessive case form that certainly 
cannot be explained by referring to regular sound laws only: The development of Ossetic $-y l$ from ${ }^{\star}(s-) h_{1}$ upér $(i)$ and Olonetsian $-l$ from ${ }^{*} \ddot{u} l(i) n a ̈$ could never have been reconstructed without comparative data from languages in which the adpositions have been preserved as such. For this reason, it seems rather daring to reconstruct the exact form of the Proto-Uralic postpositional stem behind the present-day $s$-cases, regardless of whether the Samoyed cases are considered as going back to the same stem. On the basis of our understanding of Proto-Uralic morphology, it can still be assumed that the hypothetical stem in question has been a two-syllable stem beginning with ${ }^{*}$ s (cf. Saami ${ }^{\star}$ seahkē and Finnic ${ }^{*}$ sekä 'mix, (sthg) mixed' as well as Finnic sisä- 'inside' mentioned in the previous section).

In addition to the exact shape of the postpositional stem presented as ${ }^{*} S V(. .$.$) - (e.g., { }^{*}$ sekä-, ${ }^{*}$ seki- or ${ }^{*}$ sex $(i)$-) in Figure 5 above, another potential problem is the fate of the genitive marker ${ }^{*} n$ in the development of the western Uralic $s$-cases, although it has been apparently preserved in Samoyed. It must be admitted that the loss of ${ }^{*}-n$ in such a context would be exceptional, but so is the agglutination of postpositions altogether. According to Sammallahti (1988: 494; 1998: 199), no stem-internal consonant clusters ${ }^{\star} n s$ can be reconstructed for Proto-Uralic or its immediate successors (but cf. Finno-Saami ${ }^{\star} n s>$ Saami $s(s)$, Finnic $(n) s$; Laanest 1975: 77; Sammallahti 1998: 54, 74, 193, 199). The cluster ${ }^{\star} n s$ may nevertheless have been possible at morpheme boundaries such as the genitive ${ }^{\star}-n$ followed by an ${ }^{*} s$-initial possessive suffix. At any rate, the diminution of the postpositional stem preceded by the genitive and followed by the primary local cases would have resulted in the fairly inelegant consonant cluster ${ }^{*}$-nsn- in the emerging inessive, and such clusters as well as ${ }^{*}$-nst-in the elative would presumably have been simplified. To be sure, assimilation $n s>s(s)$ is not unique to the most recent stages of Saami and Finnic, but one of the most common types of assimilation across the globe. As regards directional cases, it was argued earlier in connection with Table 9 that the elementary form of the Mordvin illative marker $-s$ can comfortably be regarded as the last remnant of an ancient directional postposition; $\mathrm{cf}$. also Aanaar Saami kaassâsiis 'into the box' (16) in which the "lative" element -siis goes materially back to the relational stem sis- 'inside, interior' instead of being a reduplicated ${ }^{\star} s$-lative, for example.

It seems that the hypothesis about the postpositional origins of $s$-cases also offers an explanation as to why the western Uralic languages have hardly any shared adpositions or adverbs consisting of ancient relational 
nouns in the allegedly Proto-Finno-Volgaic ${ }^{\star} s$-lative (cf. Section 4.2). If the coaffix ${ }^{*}-s$ - originates in a postpositional stem itself, it is understandable that such a stem has been used with ordinary lexical nouns but not necessarily with other postpositional stems: While postpositional phrases such as ${ }^{\star} t u l i-n$ üli- $\eta$ [fire-GEN on-LAT] 'onto the fire', ${ }^{\star} t u l i-n$ illa- $\eta$ [fire-GEN under-LAT] 'under the fire' or a more hypothetical ${ }^{\star} t u l i(-n) s e C V-\eta$ [fireGEN inside(?)-LAT] 'into the fire' have been and still are fully natural, formations such as ${ }^{* *} t u l i-n$ üli- $n$ seCV- $\eta$ [fire-GEN on-GEN inside(?)-LAT] or ${ }^{*}$ tuli- $n$ ila- $n$ seC $V$ - $\eta$ [fire-GEN under-GEN inside(?)-LAT] would have been quite useless and grammatically awkward if not fully impossible.

The new hypothesis about the common postpositional origins of western Uralic $s$-cases and Samoyed $n t$ t-cases certainly leaves some open questions and opens up new ones. However, as the postpositional hypothesis in itself can - at least outside traditional Uralistics - be considered the least unconventional way of explaining the origins of new local case suffixes, the hypothesis outlined above is free from the most uncomfortable questions that the lative theory raises ${ }^{27}$ Perhaps the most puzzling specific question concerns the origins of the Mari illative in -ške and lative in -(e)š. As seen Section 3, it seems partly unclear to which extent the latter has ever been an ordinary local case, and therefore it may be futile to try to press forms like tuleš (2) into Figure 5 as a some kind of sister form of the illative tulâs $(k o)$ (1).

On the other hand, it seems that the classical lative theory and the new postpositional hypothesis are equally ineffective in explaining the particularities of the Mari lative. As regards the illative, especially the longer variant -ške/-ško/-škö (or West Mari -šk â-/-ška) has already been a curious outlier in the previous theories on the emergence of the $s$-cases - and even more so according to the most ardent lative theorists who have regarded this compound of the latives in ${ }^{*}-s$ and ${ }^{*}-k$ as a mirror image of the Finnic and Mordvin translatives in $-k s(V)$ (cf. Section 3.3). The alteration of the longer markers with the plain -š suggests, however, that the element -ke/-ko/-kö does not necessarily belong to the original suffix but could be a later innovation akin to the agglutination of Finnic päin 'around; towards; from' to the Olonetsian, Lude and Veps elative (-st) to counteract the erosion to ${ }^{*}-s$ and the resulting merger with the likewise eroded inessive suffix, for example Olonetsian $\left.{ }^{*}\right)$ tule-sta $>$ tule-späi [fire-ELA] 'from the fire' or Veps kädespäi 'from the hand' seen in Table 1 (see, e.g., Tikka 1988, 1992: 22-23; Grünthal 2003: 117ff.; for the opposite view regarding Mari, see Alhoniemi 1967: 326ff.). The risk of 
ambiguity is lower in Mari, but at least nouns ending in - $a$ have ambiguous forms such as ola-š [city-ILL/LAT] that function as both illatives and latives (cf. unambiguous olaško and olaeš, respectively).

Perhaps the most fundamental question posed by the postpositional hypothesis ought to concern the genetic makeup of the Uralic language family and the claim that the western Uralic s-cases can go back to the Proto-Uralic or the early stages of the diversification of Uralic languages. There is no consensus about the taxonomy of the Uralic languages, even though the classical binary branching tree (Figure 1) continues to be the best-known classification. The present study does not attempt to make a major contribution to the quest for the best possible taxonomy, but especially in light of the so-called bush model by K. Häkkinen $(1983,1984)$ and the comb model by Salminen (1999; Figure 2), the Saami, Finnic, Mordvin and Mari branches can be seen on a par with Samoyed, without intermediate Finno-Volgaic, Finno-Permic or Finno-Ugric proto-languages. According to such models, these five branches are not a more motley crew than Saami, Mari, Mansi and Samoyed, which quite unquestionably share the Proto-Uralic accusative case $\left({ }^{*}-m\right)$ that has either disappeared or merged with the genitive elsewhere. Moreover, the widely accepted hypothesis about the Proto-Uralic genitive $\left({ }^{*}-n\right)$ is actually based on the very five branches that also possess the $s$-cases and ${ }^{\star} n t z$-cases discussed above. In other words, there are no evident traces of the original genitive in Permic, Khanty, Mansi or Hungarian either; the locative ${ }^{*}$-na is actually the only Proto-Uralic case that can be found in all branches.

The ultimate reasons for the development and occurrence of apparently new, secondary local cases in some - if not most - branches of Uralic and the absence of such cases elsewhere are unclear, but the same can be said of nearly all instances in which new local cases have replaced the original ones. For the westernmost Uralic languages, the development of essive ( $<$ locative $\left.{ }^{*}-n a\right)$ and partitive $\left(<\right.$ ablative $\left.{ }^{*}-t a\right)$ cases in Saami, Finnic and Mordvin (see, e.g., Alhoniemi 1989; Sammallahti 1998: 67-69; Lehtinen 2007: 78-79) might provide some functional explanations for the emergence of new local cases. On the other hand, formal differentiation between locative and "essive" cases is not needed in Udmurt, in which the original Uralic locative has also functions comparable to those of the essive cases in Saami and Finnic (Bartens 2000: 104). Also the apparently less original Mari inessive has either inherited or independently acquired essive-like functions alongside the primarily locative functions of the case (Alhoniemi 1993: 58). 
As for the development of the partitives (or "ablative" in Mordvin grammars), it remains unknown why the Proto-Uralic ablative in *-ta has not really survived as the default separative case in other languages either. In fact, it could even be questioned whether the Proto-Uralic case marker *-ta has existed as part of the inflectional paradigms of ordinary (nonrelational) nouns in the first place. What is more, it would be only logical to ask whether the Samoyed coaffix ${ }^{*}-k$ - seen in most locatives and all ablatives such as the Nganasan ablative -katz could be regarded as a cognate of the Mari postposition $g a \hat{c}$. As a matter of fact, this idea has already been raised by explaining both morphemes as combinations of a lative in ${ }^{*}-k$ and the ablative in ${ }^{\star}-t a$, but independently of each other and not at the Proto-Uralic level. The standard view on the origin of the Samoyed ablative was discussed in Section 5.1, but Szinnyei (1910: 65, 78) presented a similar yet largely forgotten explanation for Mari $g \hat{\partial} \hat{c}$. Despite alternative explanations, the problem of the origins of gấc cannot be regarded as solved (cf. Erkki Itkonen 1960: 316-317; Bereczki 2002: 35, 40ff.). As both the Samoyed ablative and Mari gấc would functionally fill the empty source case slots in Table 10 and Figure 5, a fundamentally revised reconstruction of the Proto-Uralic declension could provide a common explanation for both Nganasan tuj-kato [fire-ABL] 'from the fire' and the Mari postpositional phrase tul gấc [fire from] id. on a par with tu-t'a and tulà-š 'to the fire' as well as tu-t'onu and tulâ-što 'in the fire' (Figure 5). At any rate, it appears that despite plenty of lexical evidence in favor of the Proto-Uralic ablative in ${ }^{*}$ - $t a$ there are no Uralic languages whatsoever in which a descendant of Proto-Uralic ${ }^{\star} t u l i-t a$, for example, would normally function as a local case form (except for idioms like Erzya kudo-do kudo-s [house-ABL house-ILL] 'from house to house'). ${ }^{28}$

Critical re-evaluation of other basic tenets of traditional Uralistic may open up more slots for possible cognates of the $s$-cases. To take an example, the received view is that the illative of the Permic languages - Komi and Permyak - $e$ and Udmurt - $e$ - goes back to an earlier lative in ${ }^{*}-k$. However, as discussed in Ylikoski (2011: 257), there are actually no evident traces of such a lative in the entire Permic branch, with the exception of a solitary remark made by M. A. Castrén (1844: 20) on Izhma Komi in 1844, and even his words "Adspiratio in fine, quae propter suam acritatem per $h$ exprimi posset" refer to an $h$-like aspiration instead of any kind of plosive (cf. Erkki Itkonen 1967: 249). When all comes around, it can be noted that Castrén himself specified that the Komi illative is equivalent to the Karelian illative 
in - $h$ in words like $k u l k k u-h$ [throat-ILL] and venehe- $h$ [boat-ILL], which in turn seemed to him more original than the Finnish illative in $-h V n$ that has later been understood as the source of the shortened variants such as $-V n$ and $-h$. Furthermore, Castrén also related (id. 22) the Komi elative in -iś $(<-y s\rangle$ at Castrén) to the elatives in Saami and Finnic, but without paying attention to the palatalized nature of the sibilant $s$ that has afterwards been regarded as an obstacle to such a connection.

Finally, it can be noted that Castrén's comparisons were supported decades later by Donner (1879: 79-82), who added that the Permic inessive in -in can be related to the development of the South Estonian inessive $-n(\sim-h)$ from $-h n(a)$, which is unanimously considered a reflex of Proto-Finnic *-sna (see, e.g., Laanest 1975: 103-104; Iva 2007: 51-52). Such comparisons have occasionally resurfaced (e.g., Collinder 1962: 160), although mostly disregarded by referring to the dissimilarity of the sibilants (see, e.g., Erkki Itkonen 1966a: 274-275; Bartens 2000: 85). Meticulous reappraisal of these nearly forgotten conjectures falls, however, outside the scope of the present study.

While the traditional taxonomy of the Uralic languages has been contested and replaced by many alternative models during the past three decades, the subject matter of progressive historical Uralistics has increasingly been confined to phonology and lexicon. Indeed, many recent publications on the topic show that revisionist taxonomies and taxonomy-neutral approaches to Uralic languages have proved very fruitful in finding novel phonological and etymological correspondences within and across various branches of the language family. Both the starting point and the ending point of the present study are taxonomy-neutral in this respect. However, it seems that a taxonomy-neutral approach comes quite close to adopting the so-called bush model by K. Häkkinen $(1983,1984)$ or the comb model by Salminen (1999) seen in Figure 2. The classical binary branching perspective to the Uralic languages (Figure 1) may in a way have legitimized the tradition of being content to interpret the $s$-cases as a Finno-Volgaic innovation with no obvious traces in the branch closest to the so-called Finno-Volgaic languages, i.e. Permic. It may be recalled that Künnap's (1971: 115) only argument for dismissing Györke's (1943: 38-39) early suggestion to relate the western Uralic s-cases to the Samoyed *ntocases is that the $s$-cases are a product of the alleged Proto-Finno-Volgaic period (Section 5.1).

The lack of obvious cognates in the Ugric branch (or the entirely uncontroversial Mansi, Khanty and Hungarian branches) of the family has 
probably sealed the fate of the discussion: At the time the Finno-Volgaic lative in ${ }^{*}$-s was conceived (Jännes 1890, Setälä 1890), the Samoyed branch was little known. Even later, the Samoyed languages have long been regarded as the ultima Thule of Finno-Ugristics, and hypothetical attempts to outmaneuver the founding fathers by finding Samoyed parallels to "Finno-Volgaic innovations" absent in Permic and Ugric may have seemed rather hopeless, next to attempts to find such traces in Yukaghir or IndoEuropean. Likewise, specialists in Samoyedology have seldom focused on western Uralic. However, recent developments in historical Uralistics already demonstrate that the presentations of the classical binary branching family tree as "the commonly accepted view" of the Uralic language family are confined to outdated textbooks, and it can be anticipated that the research on the westernmost and the easternmost branches of the family will come closer to each other in the future.

The observations presented in this study will hopefully contribute to an ever better understanding of the development of Uralic as well as to the discussion about the taxonomy of the family. Furthermore, it is desirable that the new hypothesis about the origins of the $s$-cases will stimulate further research on these issues as well as critical re-evaluation of received but unquestioned wisdoms within Uralic historical morphology. ${ }^{29}$

\section{Conclusion}

In the preceding sections, the widely established view about the emergence of the western Uralic or so-called Finno-Volgaic s-cases has been re-evaluated by paying special attention to the research tradition in which phonological similarity of various grammatical morphemes has often overridden functional points of view. Moreover, as regards nominal morphology, a specifically Uralistic peculiarity is what has been dubbed the "lative paradigm" (Aikio \& Ylikoski 2007: 57-60; forthcoming; Ylikoski 2011: 256). In this tradition, various case suffixes and a number of other grammatical elements have been eagerly explained away as so-called latives - vaguely defined directional cases that are phonologically conservative but semantically far more flexible than any other cases in Uralic or other language families. Originally hypothesized by Jännes (1890) and Setälä (1890), afterwards concocted by Szinnyei (1910) and subsequently canonized by especially Finnish scholars of the 2oth century, the received theory that the $s$-cases in question are based on the Proto-Finno-Volgaic ${ }^{*} s$-lative has 
become the globally best known example of "multilayer case marking", the process in which new adverbial cases are created by piling two or occasionally even more case suffixes on top of each other (cf. Korhonen 1981a: 226-227; Aikio \& Ylikoski 2007: 58-59; forthcoming; Kulikov 2009: 445).

Unfortunately enough, the major problem of the lative theory is that it has become a piece of received wisdom in spite of never having been substantiated with convincing functional arguments, not to speak of typological parallels from other languages. At best, the lative theory and its kin in Uralistics have been propped up by referring to parallel developments in other languages within the same research tradition, but these kinds of arguments evidently suffer from circular reasoning. For example, Lehtinen (2007: 79) describes the emergence of the Finnic $s$-cases by appealing to Samoyed, in which the coaffixes ${ }^{*}-k \partial$ - and ${ }^{*}$-ntz- of locative and ablative markers are formally identical to the lative case markers. Vice versa, Mikola (2004: 102) argues for a corresponding theory for Samoyed by backing up his lative hypothesis with the behavior of the lative-cum-coaffix ${ }^{*}$-s- in Finnic. In this context, it is no wonder that as one of the most enthusiastic proponents of the combinatory capabilities of Uralic latives, Korhonen (1991: 177) went as far as to acknowledge that when comparing the Proto-Uralic lative suffix ${ }^{*}-n$ and the locative in ${ }^{*}-n V\left({ }^{\star}-n a\right)$, "[o]ne gets the impression that the locative has been made by adding something to the lative".

However, despite the seemingly common view of the origins of the $s$ cases, many acknowledged scholars have expressed doubts towards the received wisdom either by nonchalantly presenting alternative hypotheses (e.g., Bubrih 1946; Collinder 1952, 1962; Tauli 1956; Alhoniemi 1988, 2001) or by simply pointing at some of the fundamental unanswered questions that the theory raises (Wiklund 1927; K. Häkkinen 1983, 1984). Even on the basis of these ignored dissident voices it must be admitted that the received view is not uniformly accepted by historical Uralists, although that seems to be the only explanation known by many non-Uralists, including most contemporary researchers of individual languages such as Finnish.

To summarize the main claims of the present reappraisal of the origins of the western Uralic s-cases, the most important result is that the received view based on the hypothesis of a Proto-Finno-Volgaic lative and combinations of various semantically incompatible local cases is, if not utterly wrong, at least seriously deficient and typologically ill-founded in its present form. Secondly, it is maintained that when the most important synchronic facts about the morphology, syntax and semantics of Uralic 
local cases are combined with out current typological understanding of the emergence and development of case suffixes throughout the globe, the most plausible hypothesis is that also the Uralic s-cases go back to postpositional phrases:

1) As such, the $s$-cases in question appear as a western Uralic innovation shared by Saami, Finnic and Mordvin, and to a lesser extent by Mari.

2) It is also possible to hypothesize - with a need for further investigation - that the western coaffix ${ }^{*}-s$ - and the Samoyed coaffix ${ }^{*}$-nto- may share common Proto-Uralic origins.

3) Based on the fact that new local case series usually develop from postpositional phrases and very rarely if ever from case stacking, a possible common origin of the western $s$-cases and the Samoyed ${ }^{\star} n t$ - -cases is here preliminarily presented as a Proto-Uralic postpositional relational noun ${ }^{*} s V(\ldots)$ - followed by the three primary local case suffixes.

4) Further, if one is ready to relate the cases in question to the Khanty relational noun ${ }^{\star} L i \gamma$ - 'inside, interior' (Section 5.2), the most concrete candidates for the common origins of all these morphemes would be Proto-Uralic ${ }^{\star}$ sek $\ddot{a}-{ }^{*}{ }^{\star} \operatorname{seki}$ - or ${ }^{\star} \operatorname{sex}(i)$ - meaning 'inside, interior' or the like. This could also provide an explanation for the absence of a commonly accepted etymology for a Proto-Uralic spatial noun meaning inside, interior'. (Further still, if the morpheme in question is also related to Saami ${ }^{*}$ seahkē and Finnic *sekä- 'mix, (sthg) mixed', Proto-Uralic * sekë- - with the local case forms ${ }^{\star}$ sekäy, ${ }^{\star}$ sekänä and ${ }^{\star}$ sekätä - would be the alternative that best accounts for all forms.)

The postpositional hypothesis presented here not only leaves open questions, but also raises new ones and exposes new horizons to the re-evaluation of many of the traditional tenets of historical Uralistics. The main findings of the present study are similar to, but less definite than, those of Aikio and Ylikoski's (2007; forthcoming) reappraisal of the origins of the Finnic $l$-cases. While the classical views on the origins of the $s$-cases and $l$-cases seem to be equally unsubstantiated, it is much more difficult to find a comprehensive and concrete explanation for the $s$-cases, which seem to date much earlier than the Proto-Finnic period during which the $l$-cases emerged from Uralic postpositions that have remained as such in Saami, Mordvin, Mari, Permic and Samoyed. However, grammaticalization processes in which independent words such as adpositions lose their independence and become gram- 
matical affixes are by definition extraordinary, irregular processes that go starkly against the regular phonological development of a language. At the present stage of research, it seems near to impossible to reliably identify possible nominal or postpositional cognates and proto-forms of the western Uralic $s$-cases and Samoyed ${ }^{*} n t$ to-cases, but all forthcoming attempts in this direction must be appreciated as more sensible and typologically far more defensible than Jännes' (1890) and Setälä's (1890) pioneering and provisional conjectures about a lative suffix ${ }^{*}$-s probably were ever meant to be.

\section{Jussi Ylikoski Department of Language and Culture UiT - The Arctic University of Norway NO-9037 Tromsø}

\section{Notes}

1. For the so-called lative case in Mari (e.g. tul-eš '(e.g., remain/burn in a) fire', kid-eš '(e.g., remain/rub in the) hand'), see Section 2.2. Examples from Mari usually come from standard East Mari, unless otherwise specified.

2. This paper is based on a presentation at the meeting of the Finno-Ugrian Society on 18 March 2011. The main point of the presentation has been mentioned approvingly in Janhunen (2014: 316). I wish to thank the two reviewers of the paper for their highly constructive comments, as well as Luobbal Sámmol Sámmol Ánte, Jaakko Häkkinen, Tuomas Huumo, Nobufumi Inaba, Sampsa Holopainen, Petri Kallio, Seppo Kittilä, Larisa Leisiö, Juho Pystynen, Zsófia Schön and Florian Siegl for their valuable help and many insightful and inspiring comments about my findings and on earlier versions of this paper.

3. As regards more technical matters, the paper does not operate with allomorphy or abstract morphophonemes related to vowel harmony, and pays only little attention to allomorphy if that is not relevant for the present purposes. For example, the Finnish, Erzya and (East) Mari inessives usually are referred to as -ssa, -so and -šte respectively, instead of -ssal-ssä, -sel-so and -šte/-što/-štö. Disregarding the problem of defining the exact representation of palatal vowel harmony in various proto-languages, $\langle a\rangle$ is used instead of the graphically less elegant $\langle V\rangle$. Further, although the Proto-Uralic ablative is at times reconstructed as ${ }^{*}$-to or ${ }^{*}$-ti (e.g., Janhunen 1982: 30; 2014: 326; Sammallahti 1998: 66), only $<^{*}$-ta $>$ is used here. See also Notes 12,16 and 28.

4. Figures 1-3 are provided courtesy of Jaakko Häkkinen.

5. As a matter of fact, the Veps terminative in -hesai (e.g., kädhesai up to the arm/ hand'; cf. Table 1) can be etymologically labeled as the fourth $s$-case of the language, as it goes back to the illative (-he) followed by a later postposition-like particle ${ }^{*}$ sā̇en 'as far as' (Ylikoski 2011: 265-266; for analogous formations elsewhere in Finnic, see Kokko 2007: 83-84). 
6. The use of the inessive to mark possessor is very limited in the westernmost Saami languages (South Saami and Ume Saami), but widespread in the rest of Saami; for the most comprehensive description of this topic, see Inaba (2015: 172-207). As a whole, the use of local cases to express possessive roles (possessor, recipient, donor) in Saami seems to be related to, and possibly influenced by, the analogous functions of the Finnic l-cases (cf. Aikio \& Ylikoski 2007: 48-52; forthcoming; Kittilä \& Ylikoski 2011: 41-45, 50-52).

7. Jännes' wording "latiivinen -s pääte" does not necessarily mean a "lative" case marker but merely a directional (inflectional or derivational) suffix.

8. According to Setälä (1890: 411), the suffixes -lta, ${ }^{*}$-lna $(>-l l a)$ and ${ }^{*}$-len $(>-l l e)$ provided a model for the development of the $s$-cases, whereas later scholars have regarded the western Uralic (or "Finno-Volgaic") $s$-cases as a model to which the series of Finnic l-cases could be adapted (see, e.g., Aikio \& Ylikoski 2007: 12, 35, 40; forthcoming).

9. Setälä’s (1890: 413) wording “jonkinlainen latiivinen suffiksi” does not necessarily mean a case marker but merely a directional (inflectional or derivational) suffix ${ }^{*}-n$; cf. Note 7 above.

10. Alhoniemi (1967: 330) mentions that Erkki Itkonen (p.c.) had related the Mari element $-k e(-k a)$ to the Mordvin prolative in $-g a(-k a,-v a,-j a)$ instead of considering it a lative, but Itkonen (1967: 250) nevertheless regards both Mordvin and Mari elements historically as latives.

11. The word form moda-ńt'en is etymologically a dative form; in definite declension, the dative is also used in the illative function.

12. On the lative suffix ${ }^{\star}$-ń, see Note 16 .

13. In addition to the nonconformists discussed above, it can be noted that while Sammallahti (1998: 66-67, 203) subscribes to the established lative theory, he has later taken a more agnostic view in referring to "the historically obscure element ${ }^{*}{ }_{-} \boldsymbol{s}^{-}$, usually explained as a lative suffix" (Sammallahti 2009: 9). It may also be remarked that the analogous explanations for certain variants of Saami illative markers (allegedly going back to ${ }^{*}$-jen consisting of the latives in ${ }^{*}-j$ and ${ }^{*}-n$; see also Larsson 2009 , 2012: 131-133) suffer from similar methodological problems.

14. Transliterated to Mari orthography by J.Y.

15. The Udmurt non-finite in - min is traditionally analyzed as the past participle $(-m)$ in the inessive form $(-i n)$, but it seems that the form is better analyzed as a resultative participle, as its functions cannot simply be analyzed as a sum of its etymological parts.

16. In any case, the question whether the lative marker has been ${ }^{*}-\eta,{ }^{*}-n-$ traditionally mostly favored by Finnish scholars - or ${ }^{*}-n$ - mostly favored by non-Finnish scholars - is not central for the purposes of the present paper (cf. Inaba 2015: 35-43).

17. The apparently heretofore undescribed postpositional phrases such as colloquial Finnish (tulin tänne) talon ulos mäen ylös [(come.PST.1SG hither) house.GEN to.the. outside $\sim$ hill.GEN upward] '(I came hither,) to the outside of the house $\sim$ to the top of the hill (up here)' must probably be regarded as relatively recent innovations.

18. Ylikoski (2011: 270) refers to the fact that the first explanatory models in early Uralistics were provided by Neogrammarian Indo-European studies. However, our present 
understanding of common postpositional origins of case suffixes is not in contradiction with the views of early Neogrammarians who understood the role of grammaticalization and univerbation much earlier and much better than has been generally understood (cf., e.g., Paul 1880: 180; Esa Itkonen 2005: 109-110; 2009). Development of new case affixes from adpositions is not the hallmark of the Indo-European family, but this has certainly been attested especially in the border areas of the family (e.g., Ossetic, Old Lithuanian, Tocharian and Sinhala; see Kulikov 2009: 440-444).

19. Korhonen (1981b) - including the passage cited here - is largely identical to Korhonen (1979), originally published in German.

As regards the hypothetical development ${ }^{*}$ kala- $n$ lō-na [fish-GEN vicinity-LOC] >> Finnish kala-lla [fish-ADE] mentioned by Korhonen, this model goes back to Hunfalvy (1864: 301) and Donner (1879: 92). Although the most plausible explanation is to derive the Finnic adessive and the other $l$-cases from the Proto-Uralic postposition ${ }^{*} \ddot{u} l(i)-n \ddot{a}[$ on-LOC], etc., the possibility that the tripartite series of possessive $l$-cases Permic and the Mari dative (-lan) could be related to Saami ${ }^{*} l u$ - and Finnic ${ }^{*} l o o$ - is still worth further research (cf. Aikio \& Ylikoski 2007: 52; forthcoming; Ylikoski 2011: 258-259).

20. In Samoyedology, the label "dative" is often preferred to "lative", without difference in meaning (cf. Inaba 2015: 41-42). For the sake of clarity and compatibility with western Uralic, the label "lative" is used in the discussion in this paper.

21. For the terminative, egressive and prolative in Permyak as well as the Hungarian terminative, see Ylikoski (2011). As for the relatively simple makeup of directional expressions in Uralic, the most extreme examples also include postposition series such as Finnish luo- $\varnothing /$ tykö- $\emptyset$ 'to the vicinity of' : luo-naltykö-nä 'in the vicinity of ': luo-taltykö-ä 'from the vicinity of' and Udmurt dor- $i$ : dor-in : dor-iś id.

22. As a matter of fact, Mikola and Künnap differentiate between the problems of the origins of the lative suffix and plural markers in Samoyed, but at the same time they accuse each other of many inconsistencies and ambiguities, and it is easy to agree with both on this issue. The details of the debate are not relevant for the purposes of the present study.

23. The established methods of syntactic reconstruction cannot offer a firm answer to the question of whether the Proto-Uralic postpositions have taken their complements in the genitive, nominative or some other case. In fact, not even the order of adpositions and their complements in Proto-Uralic has ever been proven on the basis of the overwhelming preponderance of postpositions throughout the family. Only today's morphology such as possible traces of genitive complements in Samoyed local cases may provide solid evidence of the use of the genitive in yesterday's syntax such as in Proto-Uralic adpositional phrases.

24. Larisa Leisiö has kindly informed me that Katzschmann's $<$ tuut'onu $>$ is a misspelling of tuutənu, a marginal variant of tut'ənu.

25. For example, successors of the Proto-Uralic postpositions ${ }^{*} \ddot{u} l(i)-n \ddot{a}\left[\right.$ on-LOC], ${ }^{*} \ddot{u} l(i)-$ $t a ̈$ [on-ABL] and ${ }^{*} \ddot{u} l i-\eta$ [on-LAT] are still found as postpositions in most Uralic languages, but barely in Finnic and Southern Permyak, in which the original postpositions have become case suffixes. In the same vein, as the Estonian cognate of Finnish kanssa 'with' has become the comitative case marker (isa-ga [father-сом] 'with the 
father'; cf. Finnish isä-n kanssa [father-GEN with] id.), it is no longer a postposition, but has survived as an adverb only: isa ka 'the father, too' like Finnish isä kanssa id. (cf. Aikio \& Ylikoski 2007: 40-41; forthcoming).

26. I wish to thank Luobbal Sámmol Sámmol Ánte for mentioning the existence of the Khanty stem in question.

27. Recall, for example, the typologically ill-founded and chronologically challenging confusion sketched in Figure 4 and lative theorists' indifference to the origins of the Proto-Finno-Volgaic ${ }^{*} s$-lative.

28. Although the present article operates with the Proto-Uralic ablative reconstructed as *-ta (see Note 3), especially Samoyed ablatives but also Mari gấc 'from' and other formatives in $-\dot{c}$ are better explained by ${ }^{*}-t i$. This said, both Nganasan tujkata 'from the fire' and Mari phrase tul gấc id. could derive from something like ${ }^{\star} t u l i k V(\ldots) t i$ or ${ }^{*}$ tuli $(-n) k V(\ldots) t i$. However, a coaffix like the Samoyed ${ }^{*}-k \jmath$ - does not necessarily need to represent the first syllable of earlier postpositions: Northern Udmurt dialects have acquired new local cases with the "coaffix" -ń- as a result of the suffixation of the postpositions dine 'to the vicinity of' and dińin 'in the vicinity of' in postpositional phrases such as nil diń-e [girl at-ILL] and nil diń-in [girl at-INE], yielding new case forms nilńe 'to (the vicinity of) the girl' and nilnín 'at (the vicinity of) the girl' (see Ylikoski 2011: 245 and references therein). On the other hand, if the Samoyed coaffix ${ }^{*}$-ntz- is supposed to go partly back to the Proto-Uralic genitive in ${ }^{*}-n$, it seems more reasonable to presume that the agglutinated element ${ }^{*}$-ta- - and ${ }^{*}-s$ - of the westernmost branches of Uralic - represent the first syllable of the original postpositions.

I wish to emphasize that the above speculation about a possible common origin of the Nganasan ablative tujkata 'from the fire' and the Mari postpositional phrase tul gấ id. must be understood as a highly hypothetical alternative to the classical lative theories and not as an earnest reconstruction of the Proto-Uralic expression for 'from the fire'.

29. I wish to acknowledge the danger of what has been dubbed "Teeter's Law" after the Algicist Karl V. Teeter (see, e.g., Hock 2007: 274-275): "The language of the family you know best always turns out to be the most archaic." It appears that similar reasons have often contributed to the reconstruction of Proto-Uralic ever since E. N. Setäläs theory of the Proto-Uralic origins of consonant gradation in Finnic, Saami and Samoyed. Our standard view of Proto-Uralic would presumably be quite different if the research tradition had been established and dominated by native speakers of Mari and Nganasan, for example. 
Jussi Ylikoski

\section{Abbreviations}

$\begin{array}{llll}1 & \text { first person } & \text { ILL } & \text { illative } \\ 3 & \text { third person } & \text { INE } & \text { inessive } \\ \text { ABL } & \text { ablative } & \text { INF } & \text { infinitive } \\ \text { ACC } & \text { accusative } & \text { INS } & \text { instructive/instrumental } \\ \text { ADE } & \text { adessive } & \text { IPFV } & \text { imperfective } \\ \text { APPR } & \text { approximative } & \text { ITER } & \text { iterative } \\ \text { APPRELA } & \text { approximative-elative } & \text { LAT } & \text { lative } \\ \text { APPRINE } & \text { approximative-inessive } & \text { LOC } & \text { locative } \\ \text { COM } & \text { comitative } & \text { NEG } & \text { negative verb } \\ \text { COMP } & \text { complement } & \text { NOM } & \text { nominative } \\ \text { CVB } & \text { converb } & \text { PL } & \text { plural } \\ \text { DAT } & \text { dative } & \text { PROL } & \text { prolative } \\ \text { DEF } & \text { definite } & \text { PRS } & \text { present tense } \\ \text { DPT } & \text { discourse particle } & \text { PST } & \text { past tense } \\ \text { ELA } & \text { elative } & \text { PST2 } & \text { second past tense } \\ \text { ESS } & \text { essive } & \text { PTCP } & \text { participle } \\ \text { EX } & \text { existential } & \text { PTV } & \text { partitive } \\ \text { EXCESS } & \text { excessive } & \text { REL } & \text { relative } \\ \text { GEN } & \text { genitive } & \text { RES } & \text { resultative } \\ \text { GENACC } & \text { genitive-accusative } & \text { SG } & \text { singular }\end{array}$

\section{References}

Ahlqvist, August 1863: Om Ungerska språkets förvandtskap med Finskan. - Suomi II: 1. 1-6o. Helsinki.

- 1877: Suomen kielen rakennus. Vertaavia kieliopillisia tutkimuksia. I. Nominien Synty ja Taivutus. Suomalainen Runo-oppi. Suomalaisen Kirjallisuuden Seura. Helsinki.

Aikio, Ante 2006: On Germanic-Saami contacts and Saami prehistory. - JSFOu 91. 9-55.

Aıкıо 2012 = Luobbal Sámmol Sámmol Ánte (Aikio, Ante): On Finnic long vowels, Samoyed vowel sequences and Proto-Uralic ${ }^{*} x$. - Tiina Hyytiäinen, Lotta Jalava, Janne Saarikivi \& Erika Sandman (eds): Per Urales ad Orientem: Iter polyphonicum multilingue. Festskrift tillägnad Juha Janhunen på hans sextioårsdag den 12 februari 2012. MSFOu 264. Société Finno-Ougrienne. Helsinki. 227-250.

- 2014 = Luobbal Sámmol Sámmol Ánte (Aikio, Ante): The Uralic-Yukaghir lexical correspondences: genetic inheritance, language contact or chance resemblance? FUF 62. 7-76.

Aikio, ANTE \& Ylikoski, JUssi 2007: Suopmelaš gielaid $l$-kásusiid álgovuođđu sáme- ja eará fuolkegielaid čuovggas. - Jussi Ylikoski \& Ante Aikio (eds): Sámit, sánit, sátnehámit. Riepmočála Pekka Sammallahtii miessemánu 21. beaivve 2007. MSFOu 253. Société Finno-Ougrienne. Helsinki. 11-71.

- (forthcoming): The origin of the Finnic l-cases. - Fenno-Ugrica Suecana Nova Series 15. 
AJANKI, Rigina 2014: The grown-up siblings: history and functions of Western Uralic ${ }^{*}$ kse. - FUF 62. 241-282.

Alhoniemi, Alho 1967: Über die Funktionen der Wohin-Kasus im Tscheremissischen. MSFOu 142. Société Finno-Ougrienne. Helsinki.

- 1988: Postpositiorakenteiden synkroniaa ja diakroniaa. - Sananjalka 30. 27-43.

- 1989: Suomen ja mordvan vanhat erosijat omilla teillään. - Sananjalka 31. 21-29.

- 1993: Grammatik des Tscheremissischen (Mari). Mit Texten und Glossar. Buske. Hamburg,

— 2001: Über den alten und neuen Lokalkasussuffixe im Tscheremissischen. - FUF 56. 95-115.

- 2004: Diachrone und synchrone Untersuchungen zum Tscheremissischen. - FUF 58. 325-334.

Alvre, Paul 1966: si-mitmuse probleeme. - Keel ja Kirjandus 1966: 3. 156-164.

Aminoff, Torsten 1871: Etelä-Pohjanmaan kielimurteesta Tutkimus. [Helsinki.]

Anduganov 1991 = Андуганов, Юрий Владимирович: Историческая грамматика марийского языка. I. Синтаксис. Марийское книжное издательство. ЙошкарОла.

Anttila, Raimo 1989: Historical and comparative linguistics. Benjamins. Amsterdam.

ArIste, PAUl 1954: Sisekohakäänete kujunemisest läänemere keeltes. - Eesti NSV Teaduste Akadeemia toimetised 1. 41-50.

ÁtÁNYI, IsTváN 1941: A lapp melléknevek attributív-predikatív alakpárjainak kérdéséhez. - Nyelvtudományi közlemények 51. 307-355.

BALASSA, JózSEF 1884: A szóvégző önhangzók a magyarban. - Nyelvtudományi közlemények 19. 133-160.

BARTENS, RAIJA 1978: Synteettiset ja analyyttiset rakenteet lapin paikanilmauksissa. MSFOu 166. Société Finno-Ougrienne. Helsinki.

- 1999: Mordvalaiskielten rakenne ja kehitys. MSFOu 232. Société Finno-Ougrienne. Helsinki.

- 2000: Permiläisten kielten rakenne ja kehitys. MSFOu 238. Société Finno-Ougrienne. Helsinki.

BEKE, ÖDÖN 1911: Cseremisz nyelvtan. Magyar Tudományos Akadémia. Budapest.

BereczKi, GÁBOR 1988: Geschichte der Wolgafinnischen Sprachen. - Denis Sinor (ed.): The Uralic languages. Description, history and foreign influences. Handbuch der Orientalistik 8: Handbook of Uralic studies 1. E. J. Brill. Leiden. 314-350.

- 2002: A cseremisz nyelv történeti alaktana. Kossuth Egyetemi Kiadó. Debrecen.

Blake, Barry J. 2001: Case. Cambridge University Press. Cambridge.

Blomstedt, OsKar Aukusti Frithiof 1869: Halotti Beszéd ynnä sen johdosta Wertailevia Tutkimuksia Unkarin, Suomen ja Lapin kielissä. J. Kr. Frenckell. Helsinki.

Bubrin 1946 = Бубрих, Д. В.: Происхождение с-овых внутренно-местных падежей в западных группировках финно-угорских языков. - Ученые записки КарелоФинского государственного университета 1. 27-45.

- 1953 = Бубрих, Д. В.: Историческая грамматика эрзянского языка. Мордовское книжное издательство. Саранск.

- 1955 = Бубрих Д. В.: Историческая морфология финского языка. Академия наук СССР. Москва \& Ленинград. 
Budenz, Josef 1879: Ueber die Verzweigung der ugrischen Sprachen. Separat-Abdruck aus der Festschrift zum fünfzigjährigen Doctorjubiläum des Herrn Professor Benfey. Beiträge zur Kunde der indogermanischen Sprachen IV. Göttingen.

BUDENZ, József 1886: Az ugor nyelvek összehasonlító alaktana. Első rész: Az ugor nyelvek szóképzése II. Névszóképzés. - Nyelvtudományi Közlemények 20. 401-474.

- 1891: Alaktani egyezés az ugor és szamojéd nyelvekben: a localis casusragok. - Hunfalvy-album. Hunfalvy Pál félszázados akadémiai tagsága emlékére kiadják tisztelöi. Horyánszky Viktor Kiadása. Budapest.

Castr[É] N, Matthias Al[e]Xander 1839: De affinitate declinationum in lingua Fennica, Esthonica et Lapponica. Typis Frenckellianis. Helsingforsiae.

Castrén, Matthias Alexander 1844: Elementa grammatices Syrjaenae. Simelius. Helsingforsiae.

Castrén, M. A. 1845: Elementa grammatices Tscheremissce. J. Karsten. Kuopio.

COLLINDER, BJÖRN 1952: Uralaltaisch. - Ural-Altaische Jahrbücher 24: 3-4. 1-26.

- 1960: Comparative grammar of the Uralic languages. Almqvist \& Wiksell. Stockholm.

- 1962: Introduktion till de uraliska språken. Finskan och dess frändespråk. Natur och Kultur. Stockholm.

Creissels, Denis 2009: Spatial cases. - Andrej Malchukov \& Andrew Spencer (eds): The Oxford handbook of case. Oxford University Press. Oxford. 609-625.

DEWOS = STEINITZ, WolFGANG 1966-1993: Dialektologisches und etymologisches Wörterbuch der ostjakischen Sprache. Akademie Verlag. Berlin.

Donner, Отto 1879: Die gegenseitige Verwandtschaft der finnisch-ugrischen Sprachen. Abdruck aus den Acta Soc. Scient. Fennicæ. Tom. XI. Druckerei der Finnischen Litteratur-Gesellschaft. Helsingfors.

- 1881: Die samojedischen Sprachen und die finnisch-ugrischen. - Atti del IV Congresso Internazionale degli Orientalisti tenuto in Firenze nel settembre 1878. II. Le Monnier. Firenze:.231-251.

Filchenko, Andrey Y. 2010: Aspect of the grammar of Eastern Khanty. TSPU Press. Tomsk.

FrIIS, J. A. 1856: Lappisk Grammatik. Udarbeidet efter den finmarkiske Hoveddialekt eller Sproget, saaledes som det almindeligst tales i norsk Finmarken. J. W. Cappelen. Christiania.

GaLkin 1964 = Галкин, И. С.: Историческая грамматика марийского языка. Морфология. I. Марийское книжное издательство. Йошкар-Ола.

Grünthal, Rino 2003: Finnic adpositions and cases in change. MSFOu 244. Société Finno-Ougrienne. Helsinki.

Györke, József 1943: Tö, képző, rag (szó- vagy jelrésztan). A Magyar Nyelvtudományi Társaság kiadványai 67. Magyar Nyelvtudományi Társaság. Budapest.

HÄKKINEN, JААKKO 2007: Kantauralin murteutuminen vokaalivastaavuuksien valossa. [Master's thesis, University of Helsinki.]

- 2009: Kantauralin ajoitus ja paikannus: perustelut puntarissa. - JSFOu 92. 9-56.

- 2012: After the protolanguage: invisible convergence, false divergence and boundary shift. - FUF 61. 7-28.

- 2013: Historiallisen kielitieteen vertailevat menetelmät. - Leena Kolehmainen, Matti Miestamo \& Taru Nordlund (eds): Kielten vertailun metodiikka. Suomalaisen Kirjallisuuden Seura. Helsinki. 171-218. 
HÄKKINEN, KaISA 1983: Suomen kielen vanhimmasta sanastosta ja sen tutkimisesta. Suomalais-ugrilaisten kielten etymologisen tutkimuksen perusteita ja metodiikkaa. Turun yliopiston suomalaisen ja yleisen kielitieteen laitoksen julkaisuja 17. Turun yliopisto. Turku.

- 1984: Wäre es schon an der Zeit, den Stammbaum zu fällen? - Ural-Altaische Jahrbücher. Neue Folge 4. 1-24.

- 2002: Suomen kielen historia 1. Suomen kielen äänne- ja muotorakenteen historiallista taustaa. Turun yliopiston suomalaisen ja yleisen kielitieteen laitoksen julkaisuja 69. Turun yliopisto. Turku.

HAKULINEN, LAURI 1941: Suomen kielen rakenne ja kehitys. Ensimmäinen osa. Äänne- ja muoto-oppia. Otava. Helsinki.

- 1961: Suomen kielen rakenne ja kehitys. Toinen, korjattu painos. Otava. Helsinki.

- 1979: Suomen kielen rakenne ja kehitys. Neljäs, korjattu ja lisätty painos. Otava. Helsinki.

HAMARI, ARJA 2014: Inflection vs. derivation. The function and meaning of the Mordvin abessive. - Franz Rainer, Francesco Gardani, Hans Christian Luschützky \& Wolfgang U. Dressler (eds): Morphology and meaning. Selected papers from the 15th International Morphology Meeting. Benjamins. Amsterdam. 163-176.

Heine, Bernd: 2009: Grammaticalization of cases. - Andrej Malchukov \& Andrew Spencer (eds): The Oxford Handbook of Case. Oxford University Press. Oxford. 458-469.

Hock, Hans Henrich 2007: Privileged languages and others in the history of historical-comparative linguistics. - Douglas A. Kibbee (ed.): History of Linguistics 2005: Selected papers from the Tenth International Conference on the History of the Language Sciences (ICHoLS X), 1-5 September 2005, Urbana-Champaign, Illinois. Benjamins. Amsterdam. 274-287.

HoNTI, LÁszLó 2006: Eräästä ugrilaisten kielten postpositioperäisestä kaasussuffiksien perheestä. - JSFOu 91. 81-91.

Hopper, Paul \& Traugott, Elizabeth Closs 2003: Grammaticalization. Cambridge University Press. Cambridge.

Hunfalvy, Pál 1864: A vogul föld és nép. Reguly Antal hagyományaiból kidolgozta Hunfalvy Pál. Eggenberger Ferdinánd Akademiai Könyvárus. Pest.

Hunmo, Tuomas \& Ojutkangas, Krista 2006: An introduction to Finnish spatial relations. Local cases and adpositions. - Marja-Liisa Helasvuo \& Lyle Campbell (eds): Grammar from the human perspective. Case, space and person in Finnish. Benjamins. Amsterdam. 11-20.

INABA, NoBUfumi 2015: Suomen dativigenetiivin juuret vertailevan menetelmän valossa. MSFOu 272. Société Finno-Ougrienne. Helsinki.

IткONEN, ERKKI 1960: Tšeremissin kielen sanaliittojen suhteesta yhdyssanoihin ja taivutusmuotoihin. - Virittäjä 64. 311-319.

— 1966a: Esiintyykö s-latiivi permiläisissä kielissä? - Virittäjä 70. 273-28o.

- 1966b: Kieli ja sen tutkimus. WSOY. Helsinki.

- 1967: Eräiden latiivin ja prolatiivin päätteiden tarkastelua. - Virittäjä 71. 249-255.

- 1977: Lapin kieli suomen kielen historian valaisijana. - Suomalaisen Tiedeakatemian Vuosikirja 1977. 121-128. 
ItKonen, EsA 2005: Analogy as structure and process: Approaches in linguistic, cognitive psychology, and philosophy of science. Benjamins. Amsterdam \& Philadelphia.

- 2009: Concerning Dahl's (2004) notion of 'linguistic complexity'. $<$ http://users.utu.fi/eitkonen/Dahl.pdf>

Iva, Sulev 2007: Võru kirjakeele sõnamuutmissüsteem. Dissertationes Philologiae Estonicae Universitatis Tartuensis 20. Tartu Ülikooli Kirjastus. Tartu.

Janhunen, Juha (ed.) 2003: The Mongolic languages. Routledge. London \& New York.

JANHUnEN, JuHA 1982: On the structure of Proto-Uralic. - FUF 44. 23-42.

- 1989: Samojedin predestinatiivisen deklinaation alkuperästä. - JSFOu 82. 298-301.

- 1998: Samoyedic. - Daniel Abondolo (ed.): The Uralic languages. Routledge. London \& New York. 457-479.

- 2001: On the paradigms of Uralic comparative studies. - FUF 56. 29-41.

- 2009: Proto-Uralic - what, where and when? - Jussi Ylikoski (ed.): The Quasquicentennial of the Finno-Ugrian Society. MSFOu 258. Société Finno-Ougrienne. Helsinki.

- 2014: Ural-Altaic: The polygenetic origins of nominal morphology in the Transeurasian zone. - Martine Robbeets \& Walter Bisang (eds): Paradigm change: In the Transeurasian languages and beyond. Benjamins. Amsterdam. 311-336.

JäNnES, Arvi 1890: Suomen partikkelimuodot. Suomalaisen Kirjallisuuden Seura. Helsinki.

Jupmele sjugnede. Bibelselskapet. [Oslo] 2013.

KAHR, JOAN CASPER 1976: The renewal of case morphology: sources and constraints. Working Papers on Language 20. Department of Linguistics, Stanford University (California). Stanford. 107-151.

Kallio, Petri 2012: The Non-initial-syllable Vowel Reductions from Proto-Uralic to Proto-Finnic. - Tiina Hyytiäinen, Lotta Jalava, Janne Saarikivi \& Erika Sandman (eds): Per Urales ad Orientem: Iter polyphonicum multilingue. Festskrift tillägnad Juha Janhunen på hans sextioårsdag den 12 februari 2012. MSFOu 264. Société Finno-Ougrienne. Helsinki. 163-175.

Karjalainen, K. F. 1948: Ostjakisches Wörterbuch. LSFU 10. Société Finno-Ougrienne. Helsinki.

KARLsSON, Fred 2000: E. N. Setälä vaarallisilla vesillä. Tieteellisen vallankäytön, käyttäytymisen ja perinteen analyysi. Suomalaisen Kirjallisuuden Seura. Helsinki.

Katzschmann, Michael 2008: Chrestomathia Nganasanica. Texte - Übersetzung Glossar - Grammatik. Books on Demand. Norderstedt.

Kettunen, Lauri 1940: Suomen murteet. III: A. Murrekartasto. Suomalaisen Kirjallisuuden Seura. Helsinki.

KIPARSKY, PAUL 2012: Grammaticalization as optimization. - Dianne Jonas, John Whitman \& Andrew Garrett (eds): Grammatical change: origins, nature, outcomes. Oxford University Press. Oxford. 15-51.

Kittilä, Seppo \& Ylikoski, Jussi 2011: Remarks on the coding of goal, recipient and vicinal goal in European Uralic. - Seppo Kittilä, Katja Västi \& Jussi Ylikoski (eds): Case, animacy and semantic roles. Benjamins. Amsterdam. 157-182.

Кокко, Ossi 2007: Inkerinsuomen pirstaleisuus. Eräiden sijojen kehitys murteen yksilöllistymisen kuvastajana. Joensuun yliopisto. Joensuu.

KolJAdenkov 1954 = Коляденков, М. Н.: Грамматика мордовских (эрзянского и мокшанского) языков. ІІ. Синтаксис. Мордовское книжное издательство. Саранск. 
Korhonen, Miкко 1975: Merkmalhaftigkeit und Merkmallosigkeit in den Finnisch-ugrischen Lokalkasussystemen. - Valmen Hallap (ed.): Congressus Tertius Internationalis Fenno-Ugristarum Tallinnae habitus 17.-23. VIII 1970: I. Acta linguistica. Valgus. Tallinn.111-117. [Reprinted: Salminen, Tapani (ed.) 1996: Typological and historical studies in language by Mikko Korhonen. A memorial volume published on the 6oth anniversary of his birth. MSFOu 223. Société Finno-Ougrienne. Helsinki. 145-152.]

- 1979: Entwicklungstendenzen des finnisch-ugrischen Kasussystems. - FUF 43: 1-21. [Reprinted: Salminen, Tapani (ed.) 1996: Typological and historical studies in language by Mikko Korhonen. A memorial volume published on the 6oth anniversary of his birth. MSFOu 223. Société Finno-Ougrienne. Helsinki. 165-178.]

- 1981a: Johdatus lapin kielen historiaan. Suomalaisen Kirjallisuuden Seuran toimituksia 370. Suomalaisen Kirjallisuuden Seura. Helsinki.

- 1981b: Typological drift in the Finno-Ugrian languages with special reference to the case system. - 한글173-174: 687-710. [Reprinted: Salminen, Tapani (ed.) 1996: Typological and historical studies in language by Mikko Korhonen. A memorial volume published on the 6oth anniversary of his birth. MSFOu 223. Société Finno-Ougrienne. Helsinki. 195-206.]

- 1991: Remarks on the structure and history of the Uralic case system. - JSFOu 83: 163-180.

Kulikov, Leonid 2009: Evolution of case systems. - Andrej Malchukov \& Andrew Spencer (eds): The Oxford handbook of case. Oxford University Press. Oxford. 439457.

KüNNAP, Ago 1971: System und Ursprung der kamassischen Flexionssuffixe. I. Numeruszeichen und Nominalflexion. MSFOu 147. Société Finno-Ougrienne. Helsinki.

- 1981: Zur Geschichte des Lativs und des Plurals im Samojedischen. - Советское финно-угроведение 17: 110-118.

- 2002: Main language shifts in the Uralic language group. LINCOM. München.

KuZNetsov 2012 = Кузнецов, Николай: Пространственная семантика местных падежей коми языка (когнитивный анализ). Dissertationes Philologiae Uralicae Universitatis Tartuensis 12. University of Tartu Press. Tartu.

LAAnest, ARvo 1975: Sissejuhatus läänemeresoome keeltesse. Eesti NSV Teaduste Akadeemia Keele ja Kirjanduse Instituut. Tallinn.

Larsson, Lars-GunNar 2009: Der Illativ Singular im Ullisjaure-Samischen. - Finnisch-Ugrische Mitteilungen 32/33: 262-269.

- 2012: Grenzen und Gruppierungen im Umesamischen. Veröffentlichungen der Societas Uralo-Altaica 83. Harrassowitz. Wiesbaden.

LeHTINEN, TAPANI 2007: Kielen vuosituhannet: suomen kielen kehitys kantauralista varhaissuomeen. Suomalaisen Kirjallisuuden Seura. Helsinki.

Leino, Pentti 2001: Henkilöviitteinen allatiivi. - Leino, Pentti \& Herlin, Ilona \& Honkanen, Suvi \& Kotilainen, Lari \& Leino, Jaakko \& Vilkkumaa, Maija 2001: Roolit ja rakenteet. Henkilöviitteinen allativi Biblian verbikonstruktioissa. Suomalaisen Kirjallisuuden Seura. Helsinki.

Leino, Pentti \& Helasvuo, Marja-Liisa \& Lauerma, Petri \& Nikanne, Urpo \& Onikкi, Tina 1990: Suomen kielen paikallissijat konseptuaalisessa semantiikassa. University of Helsinki. Helsinki. 
LöNNROT, EliAS 1841: Bidrag till Finska Språkets Grammatik. (Forts. fr. 4:de Häftet.) Suomi I: 5: 29-47.

Miкоla, TiвоR 1969: Miscellanea samojedica. - Néprajz és Nyelvtudomány 13: 17-22.

- 1979: Zur Geschichte des Plurals im Nenzischen. - Christoph Gläser \& János Pusztay (eds): Festschrift für Wolfgang Schlachter zum 7o. Geburtstag. Veröffentlichungen der Societas Uralo-Altaica 12. Harrassowitz. Wiesbaden. 189-194.

- 1988: Geschichte der samojedischen Sprachen. - Denis Sinor (ed.): The Uralic languages. Description, history and foreign influences. Handbuch der Orientalistik 8: Handbook of Uralic studies 1. E. J. Brill. 219-263. Leiden.

- 2004: Studien zur Geschichte der samojedischen Sprachen. Studia Uralo-Altaica 45. SZTE Finnugor Tanszék. Szeged.

NeKrasova 1990 = Некрасова, Галина Александровна: К проблеме возникновения вторичных падежных суффиксов в современном коми языке. - Материаль VI Международного конгресса финно-угроведов 2. Наука. Москва. 138-14о.

Noonan, Michael 2008: Case compounding in the Bodic languages. - Greville Corbett \& Michael Noonan (eds): Case and grammatical relations. Studies in honor of Bernard Comrie. Benjamins. Amsterdam. 127-147.

ӦКК = Федюнёва, Г. В. (еd.) 20оо: Ӧнія коми кыв морфология. Сыктыькар: Коми небӧг тэдзанін.

Paul, Hermann 1880: Principien der Sprachgeschichte. Niemeyer. Halle.

Plank, Frans 1995: (Re-)introducing Suffixaufnahme. - Frans Plank (ed.): Double case: Agreement by Suffixaufnahme. Oxford University Press. Oxford. 3-110.

Raamattu. Suomen Pipliaseura, 1992. Helsinki.

Rahkonen, Pauli 2013: South Eastern contact area of Finnic languages in the light of onomastics. Bookwell. Jyväskylä.

RASK, RASMUS 1832: Roesonneret lappisk Sprogloere efter den Sprogart, som bruges af Fjoeldlapperne i Porsangerfjorden i Finmarken. En Omarbejdelse af Prof. Knud Leems Lappiske grammatica. J. H. Schubothes Boghandling. København.

Ravila, Paavo 1935: Die stellung des lappischen innerhalb der finnisch-ugrischen sprachfamilie. - FUF 23: 20-65.

RÉDEI, KáROLY 1996: Zu der Geschichte des PU-PFU Kasussystems: Die Rolle der Koaffixe in der Herausbildung der Deklination. - Lars-Gunnar Larsson (ed.): Lapponica et uralica. 100 Jahre finnisch-ugrischer Unterricht an der Universität Uppsala. Vorträge am Jubiläumssymposium 20.-23. April 1994. Studia Uralica Upsaliensia 26. Uppsala. 257-271.

Rice, SAlly \& Kabata, KaORI 2007: Crosslinguistic grammaticalization patterns of the ALLATIVE. - Linguistic Typology 11: 451-514.

Riedl, Anselm Mansvet 1858: Magyarische Grammatik. Braumüller. Wien.

Riese, Timothy \& Bradley, Jeremy \& Yakimova, Emma \& Krylova, Galina 2012: Онгай марий йылме: A comprehensive introduction to the Mari language. University of Vienna. Vienna.

Riese, Tiмотну 1993: Der Translativ in den uralischen Sprachen II. - Linguistica Uralica 29: 1-20.

SAARIKIVI, JANNE 2011: Saamelaiskielet - nykypäivää ja historiaa. - Irja Seurujärvi-Kari, Petri Halinen \& Risto Pulkkinen (eds): Saamentutkimus tänään. Suomalaisen Kirjallisuuden Seura. Helsinki. 77-119. 
SAARINEN, Sirkka 2001: Das finnisch-wolgaische Ableitungssuffix ${ }^{\star} k s e .-$ Néprajz és nyelvtudomány 41: 2: 241-247.

SAdler, Louisa \& Nordlinger, Rachel 2006: Case stacking in Realizational Morphology. - Linguistics 44: 459-487.

SAlminen, TAPAni 1999: Euroopan kielet muinoin ja nykyisin. - Paul Fogelberg (ed.): Pohjan poluilla. Suomalaisten juuret nykytutkimuksen mukaan. Bidrag till kännedom av Finlands natur och folk 153. Helsinki. 13-26.

- 2014: Suomalais-samojedilaisia muotovertailuja. - Nobufumi Inaba, Jorma Luutonen, Arja Hamari \& Elina Ahola (eds): Juuret marin murteissa, lehvät yltää Uraliin. Juhlakirja Sirkka Saarisen 6o-vuotispäiväksi 21.12.2014. MSFOu 270. Société FinnoOugrienne. Helsinki. 289-300.

Sammallahti, Pekka 1988: Historical phonology of the Uralic languages. - Denis Sinor (ed.): The Uralic languages. Description, history and foreign influences. Handbuch der Orientalistik 8: Handbook of Uralic studies 1. E. J. Brill. Leiden. 478-554.

- 1998: The Saami languages. An introduction. Davvi Girji. Kárášjohka.

- 2009: On the origin of the illative singular morphology in Saami. - FUF 60: 9-28.

Samson, Ridder \& Schadeberg, Thilo C. 1994: Kiinimacho cha mahali: kiambishi tamati cha mahali -ni. - Afrikanistische Arbeitspapiere 37: 127-138.

SÄRKKä, TAUNO 1969: Itämerensuomalaisten kielten eksessiivi. Suomalaisen Kirjallisuuden Seura. Helsinki.

SAUkKonen, PAUli 1959: Myöhä - inessiivin sukulainen? - Verba docent. Juhlakirja Lauri Hakulisen 6o-vuotispäiväksi 6.10.1959. Suomalaisen Kirjallisuuden Seura. Helsinki. 252-254.

Schön, Zsófia 2014: Postpositionale Konstruktionen in chantischen Dialekten. $\mathrm{PhD}$ thesis. Ludwig-Maximilians-Universität. München.

Schultze-Berndt, Eva \& Himmelmann, Nikolaus P. 2004: Depictive secondary predicates in crosslinguistic perspective. - Linguistic Typology 8: 59-131.

N.-Sebestyén, IrÉn 1958: Die possessiven Fügungen im Samojedischen und das Problem des uralischen Genitivs (II.). - Acta Linguistica Academiae Scientiarum Hungaricae 7: 273-340.

SerebrenNikov 1964 = Серебренников, Борис Александрович: Основныле тинии развития падежной и глагольной систем в уральских языках. Наука. Москва.

SETÄLÄ, E. N. 1890: Yhteissuomalaisten klusiilien historia. Luku yhteissuomalaisesta äännehistoriasta. Suomalaisen Kirjallisuuden Seura. Helsinki.

- 1915: Zur Frage nach der Verwandtschaft der finnisch-ugrischen und samojedischen Sprachen. - JSFOu 30(5): 1-104.

SIKOR $=$ SIKOR. UiT The Arctic University of Norway and the Norwegian Saami Parliament's Saami text collection. Version 01.03.2015. <http://gtweb.uit.no/korp/>

Simonyi, Siegmund 1907: Die ungarische Sprache. Geschichte und Charakteristik. Trübner. Strassburg.

SJögren, AND. JoH. 1828: Anteckningar om församlingarne i Kemi-Lappmark. Helsingfors. Soкolov 2013 = Соколов, Александр (ed.): Марийская история в тицах. Куван рывыж малакай. <http://www.marihistory.ru/index.php/2011-04-18-17-14-30/31612013-08-01-12-23-51>

Solovar 2014 = Соловар, В. Н.: Хантыйско-русский словарь (казымский диалект). Формат. Тюмень. 
SSA = ItKonen, ERKKi \& Ulla-MAIJA Kulonen (eds) 1992-2000: Suomen sanojen alkuperä. Etymologinen sanakirja. Kotimaisten kielten tutkimuskeskus - Suomalaisen Kirjallisuuden Seura. Helsinki.

StIPA, GÜNTER JOHANnES 1990: Finnisch-ugrische Sprachforschung von der Renaissance bis zum Neopositivismus. MSFOu 206. Société Finno-Ougrienne. Helsinki.

SzInNYeI, Josef 1910: Finnisch-ugrische Sprachwissenschaft. Göschen'sche Verlagshandlung. Leipzig.

- 1922: Finnisch-ugrische Sprachwissenschaft. Zweite, verbesserte Auflage. Walter de Gruyter. Leipzig.

TAuli, VAlter 1956: The origin of affixes. - FUF 32: 170-225.

TereshCHeNко 1973 = Терещенко, Н. М.: Синтаксис самодийских языков. Простое предложение. Наука. Ленинград.

TikкA, ToIvo 1988: Itämerensuomalaisia paikallissijojen synkresiatapauksia. - Muusa Ojanen \& Ilkka Savijärvi (eds): Kielikontakteja I. Tutkimuksia venäjän ja itämerensuomalaisten kielten alalta. Kielitieteellisiä tutkimuksia 13. Joensuun yliopisto. Joensuu.

- 1992: Vepsän suffiksoituneet postpositiot. Kieliopillisiin sijoihin liittyvä suffiksoituminen. Studia Uralica Upsaliensia 22. Uppsala.

UEW = RÉDEI, KÁROLY (unter Mitarbeit von Marianne Bakró-Nagy, Sándor Csúcs, István Erdélyi, László Honti, Éva Korenchy, Éva K. Sal und Edit Vértes) 1988-1991: Uralisches etymologisches Wörterbuch. 1-3. Harrassowitz. Wiesbaden.

USo = У Согонь. Библим сӓрӥшӹ институт, 2014. Хельсинки.

USu = У Сугынъ. Библийым кусарыше институт, 2007. Хельсинки.

VARes, VeSA \& HäKKINEN, KAISA 2001: Sanan valta. E. N. Setälän polittinen, yhteiskunnallinen ja tieteellinen toiminta. WSOY. Helsinki.

Vértes, Edith (ed.) 2001: H. Paasonens surgutostjakische Textsammlungen am Jugan. Neu transkribiert, bearbeitet, übersetzt und mit Kommentaren versehen von Edith Vértes. MSFOu 240. Société Finno-Ougrienne. Helsinki.

WAGNER-NAGy, BEÁTA (ed.) 2002: Chrestomathia nganasanica. SZTE Finnugor Tanszék - MTA Nyelvtudományi Intézet. Szeged - Budapest.

Weske, M[ICHAeL] 1884: Eesti keele nimisõna muudete lõppudest. Ruumi muudete lõppudest I. - Eesti Kirjameeste Seltsi aastaraamat 1883: 82-90.

WichmanN, YRJÖ 1923-1924: Zur permischen Grammatik. - FUF 16: 146-163.

Wiklund, Károly Bernát 1927: A translativus. - Magyar Nyelv 23: 321-328.

YLiкoski, JUssi 2011: A survey of the origins of directional case suffixes in European Uralic. - Seppo Kittilä, Katja Västi \& Jussi Ylikoski (eds): Case, animacy and semantic roles. Benjamins. Amsterdam. 235-280.

- 2015: From compounds to case marking: Prolatives in South Saami and Lule Saami. - Finnisch-Ugrische Mitteilungen 39: 101-155.

Zhivlov, MikhaIL 2014: Studies in Uralic Vocalism III. - Journal of Language Relationship 12: 113-148. 